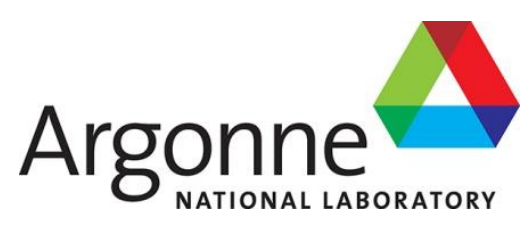

ANL/GTRI/TM-14/10

\title{
RELAP5 Model Description and Validation for the BR2 Loss-of-Flow Experiments
}

Nuclear Engineering Division 


\begin{abstract}
About Argonne National Laboratory
Argonne is a U.S. Department of Energy laboratory managed by UChicago Argonne, LLC under contract DE-AC02-06CH11357. The Laboratory's main facility is outside Chicago, at 9700 South Cass Avenue, Argonne, Illinois 60439. For information about Argonne and its pioneering science and technology programs, see www.anl.gov.
\end{abstract}

\title{
DOCUMENT AVAILABILITY
}

Online Access: U.S. Department of Energy (DOE) reports produced after 1991 and a growing number of pre-1991 documents are available free via DOE's SciTech Connect (http://www.osti.gov/scitech/)

\author{
Reports not in digital format may be purchased by the public from the \\ National Technical Information Service (NTIS): \\ U.S. Department of Commerce \\ National Technical Information Service \\ 5301 Shawnee Rd \\ Alexandria, VA 22312 \\ www.ntis.gov \\ Phone: (800) 553-NTIS (6847) or (703) 605-6000 \\ Fax: (703) 605-6900 \\ Email: orders@ntis.gov
}

Reports not in digital format are available to DOE and DOE contractors from the Office of Scientific and Technical Information (OSTI):

U.S. Department of Energy

Office of Scientific and Technical Information

P.O. Box 62

Oak Ridge, TN 37831-0062

www.osti.gov

Phone: (865) 576-8401

Fax: (865) 576-5728

Email: reports@osti.gov

\section{Disclaimer}

This report was prepared as an account of work sponsored by an agency of the United States Government. Neither the United States Government nor any agency thereof, nor UChicago Argonne, LLC, nor any of their employees or officers, makes any warranty, express or implied, or assumes any legal liability or responsibility for the accuracy, completeness, or usefulness of any information, apparatus, product, or process disclosed, or represents that its use would not infringe privately owned rights. Reference herein to any specific commercial product, process, or service by trade name, trademark, manufacturer, or otherwise, does not necessarily constitute or imply its endorsement, recommendation, or favoring by the United States Government or any agency thereof. The views and opinions of document authors expressed herein do not necessarily state or reflect those of the United States Government or any agency thereof, Argonne National Laboratory, or UChicago Argonne, LLC. 


\section{RELAP5 Model Description and Validation for the BR2 Loss-of-Flow Experiments}

prepared by

J.R. Licht ${ }^{1}$ and B. Dionne ${ }^{1}$

${ }^{1}$ Nuclear Engineering Division, Argonne National Laboratory

and

G. Van den Branden ${ }^{2}$, E. Sikik ${ }^{2}$ and E. Koonen ${ }^{2}$

${ }^{2}$ BR2 Reactor Department, SCK•CEN

July, 2015

This work is sponsored by the

U.S. Department of Energy, National Nuclear Safety Administration NNSA,

Office of Material Management and Minimization (M3) Reactor Conversion Program 


\section{Table of Contents}

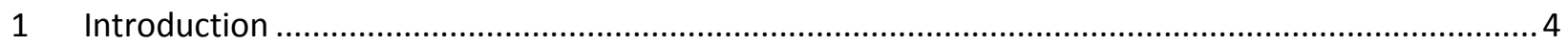

1.1 Scope

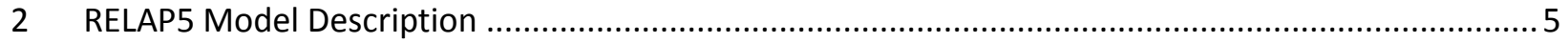

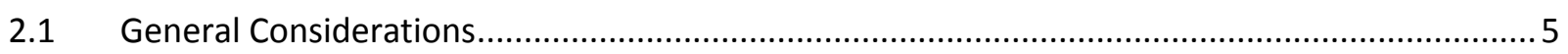

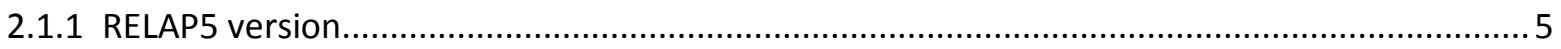

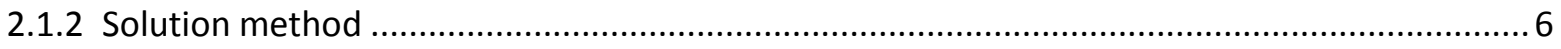

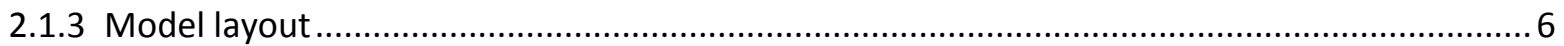

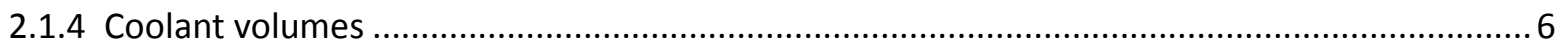

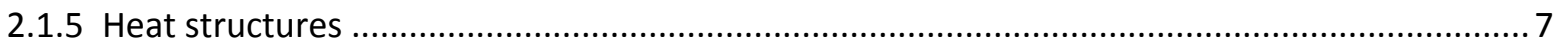

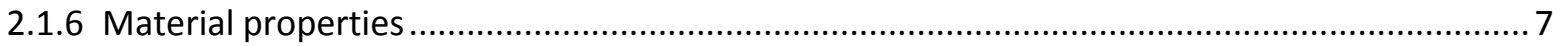

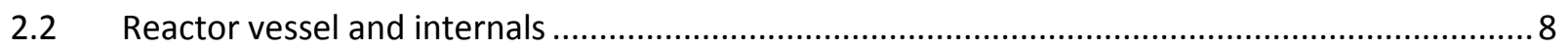

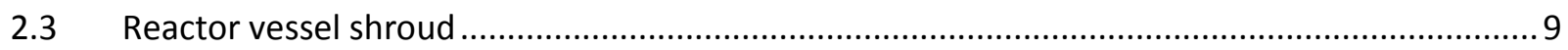

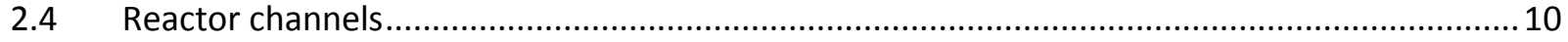

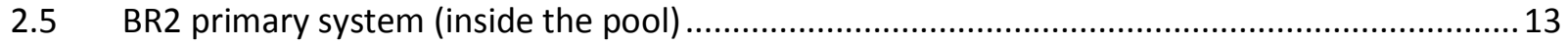

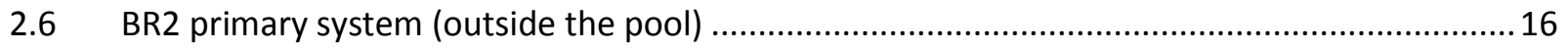

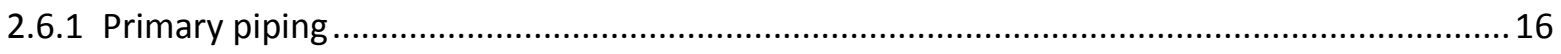

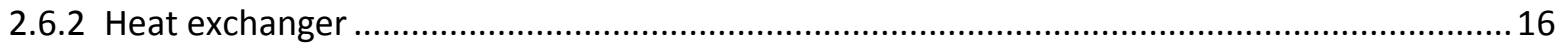

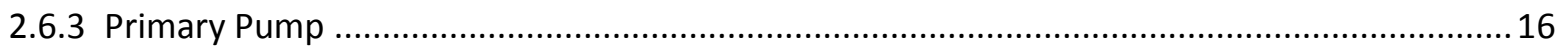

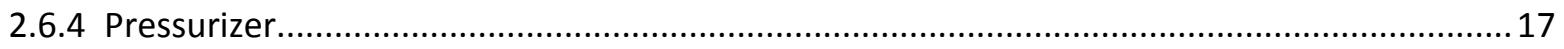

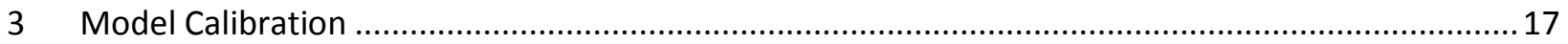

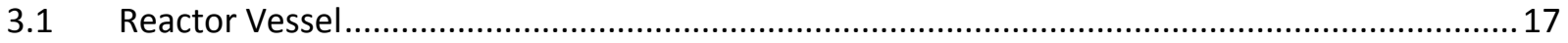

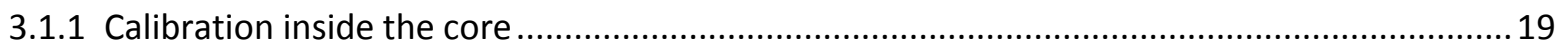

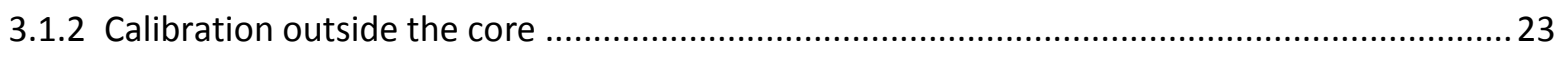

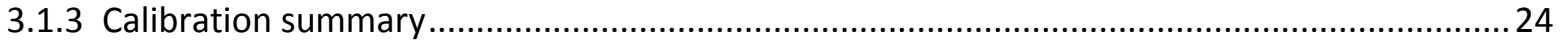

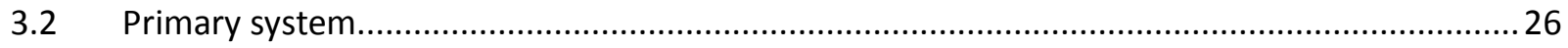

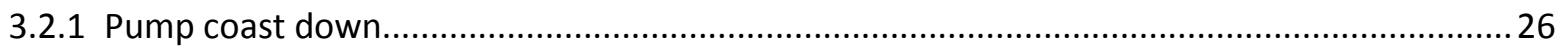

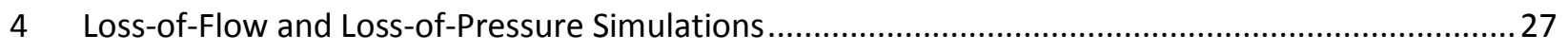

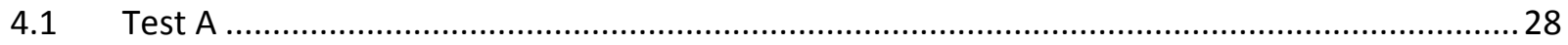

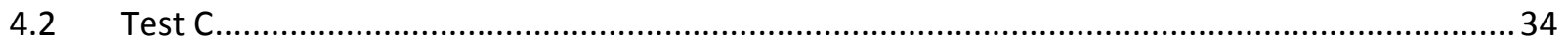

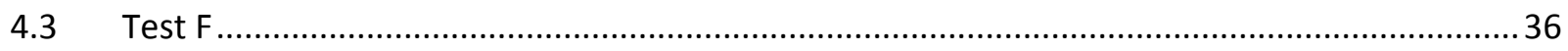

ANL/GTRI/TM-14/10 2 


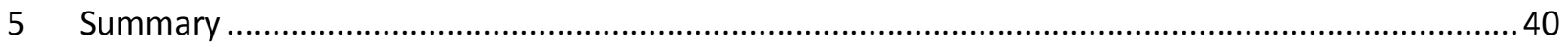

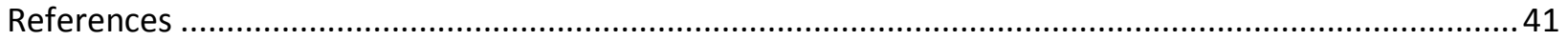

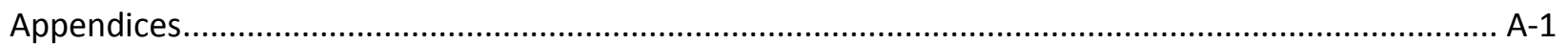

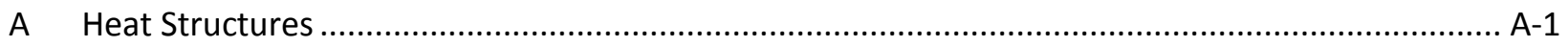

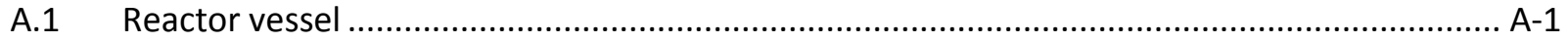

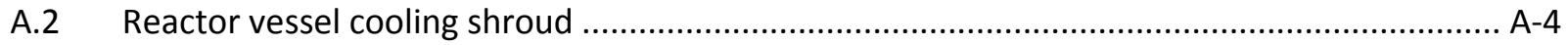

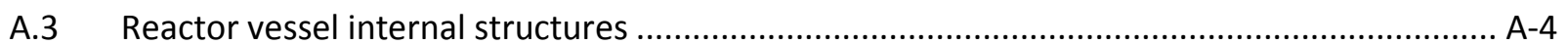

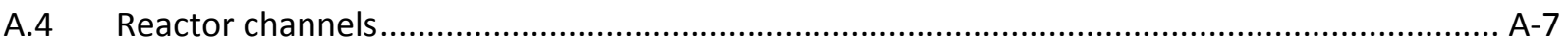

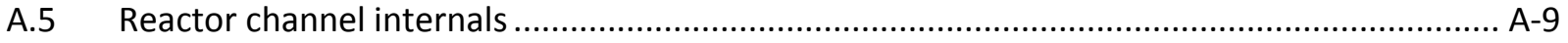

A.6 RELAP5 channel heat structures (1963 core) ................................................................... A-15

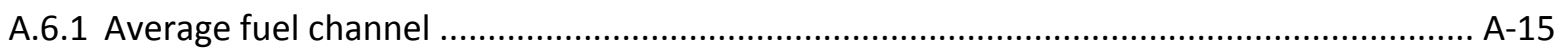

A.6.2 High heat flux fuel channel ............................................................................................... A-17

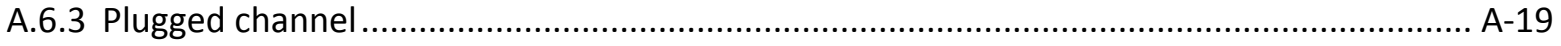

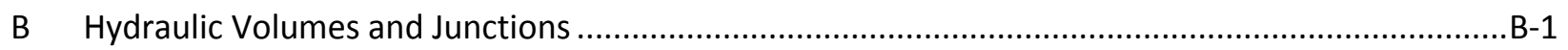

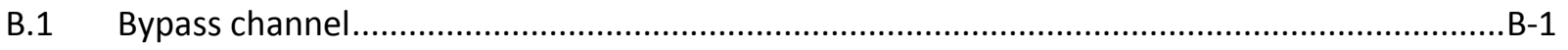

B.2 High heat flux fuel channel (1963 core) ..............................................................................

B.3 Average fuel channel (1963 core) ……............................................................................

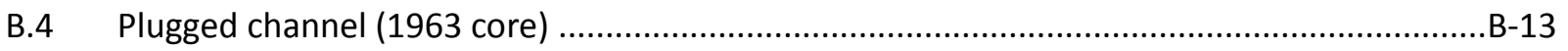

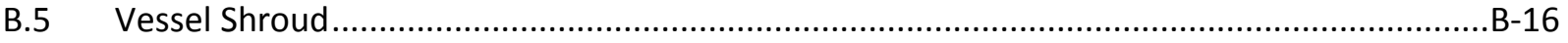

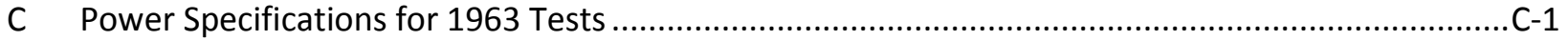

D Estimation of Peak Cladding Temperature Due to Flow Reversal ................................................. D-1 


\section{Introduction}

The US Government Highly Enriched Uranium (HEU) minimization effort is currently led by the National Nuclear Security Administration (NNSA) through the Global Reduction Threat Initiative (GTRI). The program includes developing of advanced Low Enriched Uranium (LEU) fuels along with supporting design and safety analyses and has resulted in the successful conversion from HEU to LEU of a number of research reactors around the world. As part of this initiative, the conversion of the SCK•CEN Belgian Reactor 2 (BR2) was intensified in 2007.

BR2 is a research reactor used for radioisotope production and materials testing (Figure 1). It's a tank-inpool type reactor cooled by light water and moderated by beryllium and light water. The reactor has a single primary loop containing a set of primary pumps and heat exchangers to control the coolant inlet temperature $\left(\sim 37^{\circ} \mathrm{C}\right)$ and flow rate (variable). A pressurizer maintains the vessel inlet pressure at 1.38 $\mathrm{MPa}$. In case of an accident, there are two isolation valves that can isolate the reactor core. A bypass valve can open to assist natural circulation flow through the core. A pool connection valve is available to connect the primary loop to the pool. The reactor core is located inside an aluminum pressure vessel that contains 79 channels in a hyperboloid configuration. Outside the core region the channels are stainless steel tubes; however, in the core region the channels are comprised of hexagonal beryllium with a central circular bore. The core configuration is highly variable as each channel can contain a fuel assembly, a control or regulating rod, an experimental device, or a beryllium or aluminum plug. Normally the coolant flow is downward and enters the channels through perforations in the channel walls located above the core region. The coolant exits the end of the channel at the lower support grid. Coolant can also bypass the core through gaps and cooling holes in the beryllium matrix as well as the gap between the outer edge of beryllium matrix and the pressure vessel.

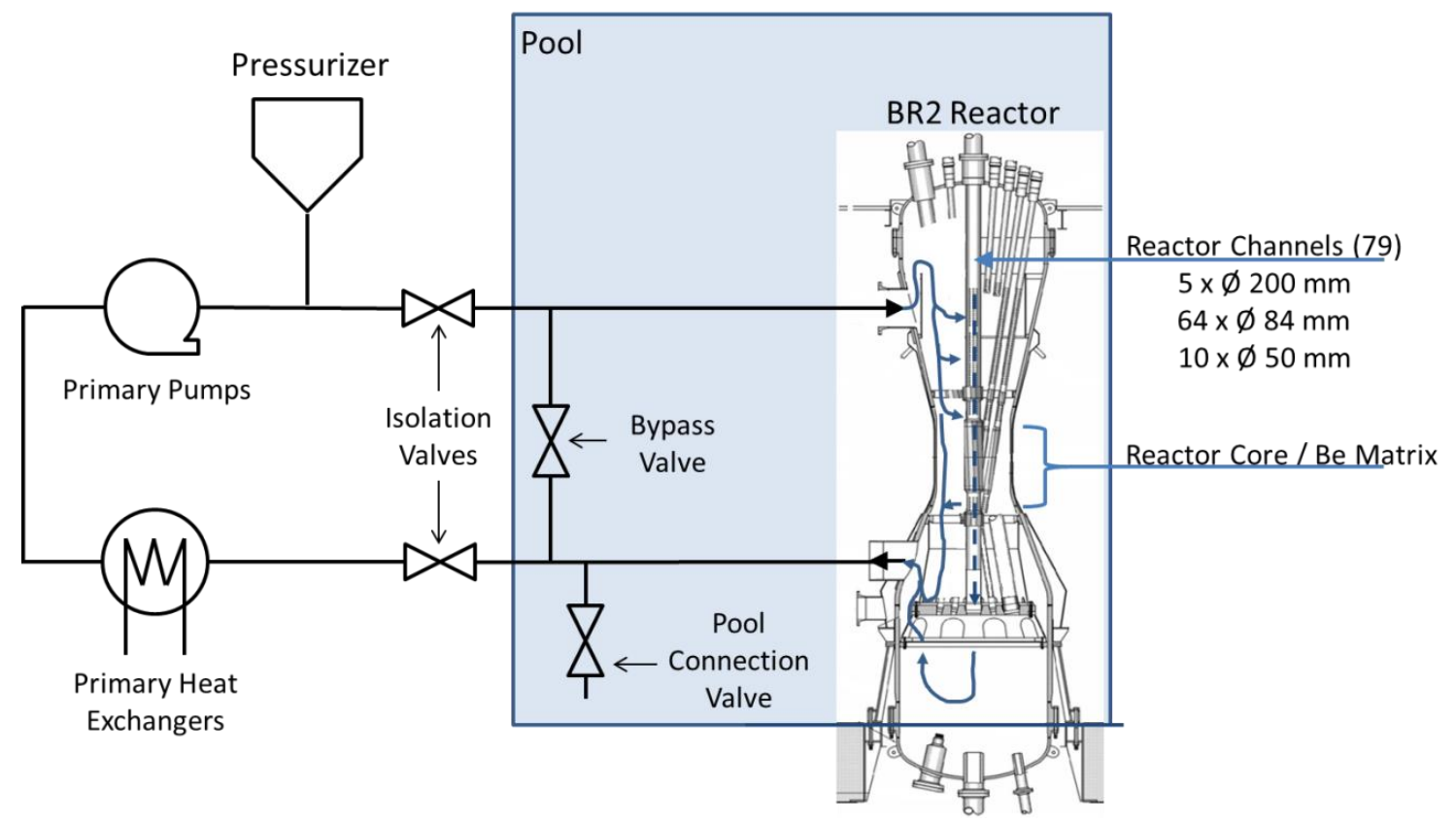

Figure 1 Conceptual drawing of BR2. 


\subsection{Scope}

In support of converting the BR2 research reactor from HEU to LEU fuel, the code RELAP5/Mod 3.3 [1] was used to simulate several Loss-of-Flow Accident (LOFA) with or without loss-of-pressure scenarios. Because the configuration of the core is variable, a representative core configuration has been defined for the fuel conversion analyses (Figure 2) [2]. However, in order to assure credibility of the predicted results, simulations have been performed for the 1963 core configuration for comparison with a number of LOFA experiments that were performed in the BR2 reactor. Additionally, experimental data was also available for steady-state flow and pressure distributions in both the BR2 facility (1962) and a hydraulic mock-up facility for various core configurations. This data was used to generate the generic minor loss coefficients applied to the RELAP5 model to obtain the proper channel flow rates and reactor pressure distributions suitable for any given core configuration.

This paper presents a description of the RELAP5 model, the calibration method used to obtain the minor loss coefficients from the available hydraulic data and the LOFA simulation results compared to the 1963 experimental tests for HEU fuel.
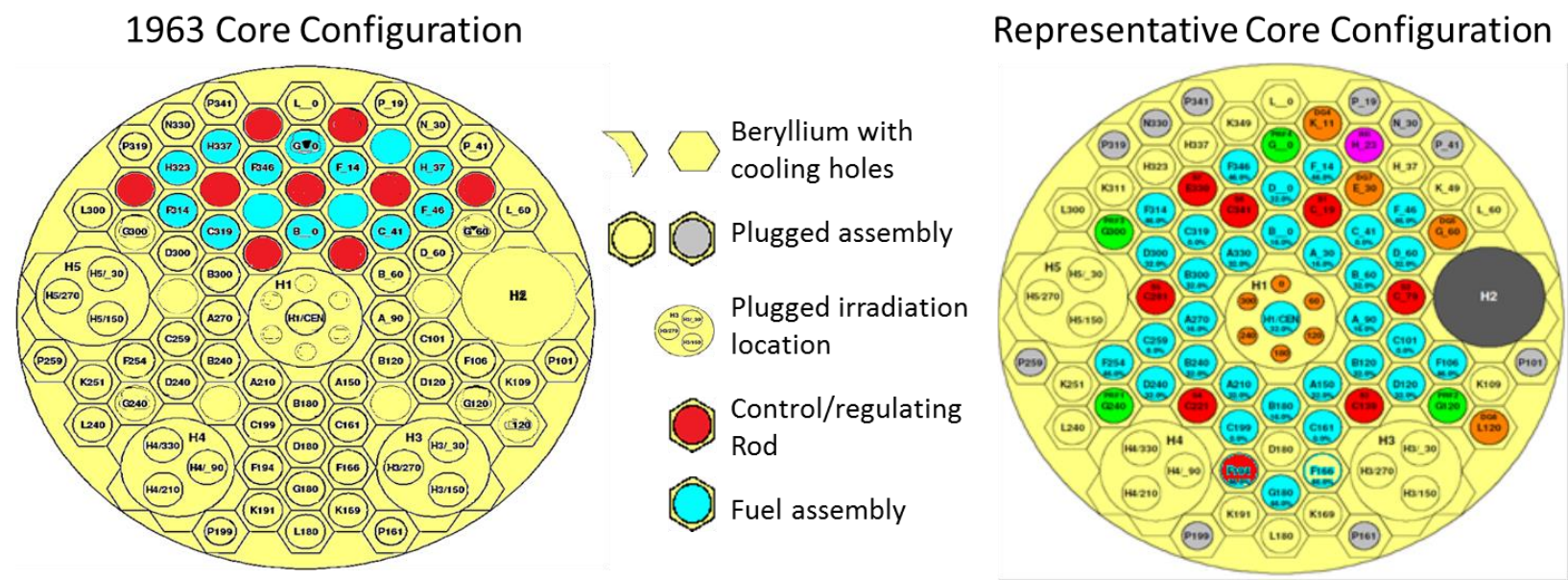

Figure 2 The 1963 and representative core configurations.

\section{RELAP5 Model Description}

\subsection{General Considerations}

A detailed description of the structures, volumes and their connections used in the current RELAP5 model is quite lengthy so only summary of this information is provided in Section 2. A detailed description of the RELAP5 heat structures and their thermal connections is given in Appendix A. Appendix B contains a detailed description of the RELAP5 coolant volumes and their junctions.

\subsubsection{RELAP5 version}

The model described in this document was developed for RELAP5/Mod 3.3 [1]. Throughout the remainder of this document, RELAP5/Mod 3.3 will be referred to as RELAP5. 


\subsubsection{Solution method}

The options selected for running the RELAP5 simulations summed to control option 7, which means the following options have been implemented:

- The hydrodynamics advancement setting was selected; it uses a mass error analysis to control the time step between the minimum and maximum time step (set to $1.1 \mathrm{e}-12 \mathrm{~s}$ and $0.1 \mathrm{~s}$, respectively).

- The heat conduction/transfer time step was set to be the same as the hydrodynamic time step.

- The heat conduction/transfer and hydrodynamics were coupled implicitly for the transient simulation. Note that the explicit method was used to achieve steady-state conditions before switching to the implicit method.

\subsubsection{Model layout}

The RELAP5 model can be thought of as being separated into three parts; the reactor vessel, the primary coolant system within the pool and the primary coolant system outside the pool. The model of the primary coolant system within the pool has been modernized by the BR2 team and is described in [3]. The model of the primary coolant system outside the pool has only received a limited number of changes and simplifications relative to previous ANL and BR2 versions of the BR2 model. These changes have been described in this document. The reactor vessel model has been modernized by the conversion team at Argonne National Laboratory (ANL) and is described in detail in this document.

\subsubsection{Coolant volumes}

Coolant volumes within the reactor vessel model were largely based on the data extracted from previous RELAP5 models and confirmed by comparison with legacy notes provided by BR2. Where applicable, updated values have been used based on the data provided in more recent BR2 design description documents (e.g. [4]). Default parameters for coolant volumes and junctions within the reactor vessel are given here:

The volume control flags tlpvbfe for pipe and snglvol components were by default set to 0000000:

- $t=0$ : no thermal front tracking

- I=0: no mixture level tracking

- $p=0$ : water packing scheme used

- $\quad v=0$ : vertical stratification model used

- $b=0$ : pipe interphase friction model used

- $f=0$ : wall friction along $x$-axis calculated

- $\quad \mathrm{e}=0$ : non-equilibrium model used
The junction control flags efvcahs for pipe and sngljun component were by default set to 0001000:

- $\quad \mathrm{e}=0$ : modified PV term not used

- $\mathrm{f}=0$ : CCFL model not applied

- $\quad \mathrm{v}=0$ : option not available

- $\quad c=1$ : choking model not applied

- $a=0$ : smooth area change

- $\mathrm{h}=0$ : non-homogeneous model applied

- $s=0$ : momentum flux both to and from volume

For pipes, the hydraulic diameter and area for the internal junctions of all volumes were by default set to 0 (internally calculated). 
To be consistent with previous models, the wall roughness for the internal surface of the reactor channels was specified as $1.6 \mathrm{e}-6$ and the wall roughness for the remainder of the reactor vessel was specified as $3.2 \mathrm{e}-6$. These values are not expected to significantly affect RELAP5 simulation results.

Exceptions to the above default parameters are discussed in the applicable sections below.

\subsubsection{Heat structures}

Heat structures were included for most of the components within the reactor pool. Heat structures throughout the reactor vessel model were discretized into 3 radial regions (4 nodes). Heat structures containing fuel where discretized into 9 radial regions ( 10 nodes), 3 for each of the cladding faces and 3 for the fuel. The following default parameters were set for the heat structure components without heat generation:

- $\quad$ the 9 word format was selected

- $\quad$ convection boundary = 101 (default convection correlations)

- $\quad$ heat transfer hydraulic diameter $=0$ (i.e. same as volume hydraulic diameter)

- $\quad$ the forward and reverse heated length $=>100$ (i.e. neglect entrance effects)

- forward and reverse loss coefficients $=0$ (not required for current geometry)

- local boiling factor $=1.0$ (no heat generation)

The following additional parameters were set for the heat structure components with heat generation:

- the 12 word format was selected

- $\quad$ natural circulation length ${ }^{1}=0.762 \mathrm{~m}$

\subsubsection{Material properties}

ses presented in this document.

Table 1 provides a summary of the material properties for use in the RELAP5 model [5]. The fresh HEU fuel (UAI $-\mathrm{Al}$ ) and long irradiated beryllium properties were used in the analyses presented in this document.

Table 1 Material Properties used in the RELAP5 model [5].

\begin{tabular}{|c|c|c|c|c|c|c|}
\hline $\begin{array}{c}\text { RELAP5 } \\
\#\end{array}$ & Material & Applies to: & Density & $\begin{array}{c}\text { Specific } \\
\text { Heat }\end{array}$ & Heat Capacity & $\begin{array}{c}\text { Thermal } \\
\text { Conductivity }\end{array}$ \\
\cline { 4 - 7 } & & & {$\left[\mathrm{kg} / \mathrm{m}^{3}\right]$} & {$[\mathrm{J} / \mathrm{kg}-\mathrm{K}]$} & {$\left[\mathrm{J} / \mathrm{m}^{3}-\mathrm{K}\right]$} & {$[\mathrm{W} / \mathrm{m}-\mathrm{K}]$} \\
\hline $1^{*}$ & AG3NE & cladding & 2670 & 880 & $2.3496 \mathrm{e} 6$ & 130 \\
\hline $2^{*}$ & Al 6061-T6 & structure & 2700 & 896 & $2.4192 \mathrm{e} 6$ & 167 \\
\hline $3^{*}$ & UAlx-Al & Fresh fuel & 3580 & 646 & $2.3124 \mathrm{e} 6$ & 80 \\
\hline 4 & UAlx-Al & B=25\% & 3580 & 646 & $2.3124 \mathrm{e} 6$ & 69 \\
\hline 5 & U-7Mo-Al & Fresh fuel & 9870 & 275 & $2.7143 \mathrm{e} 6$ & 66 \\
\hline 6 & U-7Mo-Al & B=25\% & 9870 & 275 & $2.7143 \mathrm{e} 6$ & 41 \\
\hline $7^{*}$ & $\mathrm{Be}$ & Unirradiated & 1836 & 1925 & $3.5343 \mathrm{e} 6$ & 149 \\
\hline 8 & $\mathrm{Be}$ & Long irradiation & 1836 & 1925 & $3.5343 \mathrm{e} 6$ & 50 \\
\hline
\end{tabular}

${ }^{1}$ Heat generation has only been specified in heat structures for the same length as the active fuel region $(0.762 \mathrm{~m})$. No heat generation has been specified above or below fuel region. 


\begin{tabular}{|c|c|c|c|c|c|c|}
\hline $9^{*}$ & SS 304L & Vessel etc. & 8000 & 500 & $4.0000 \mathrm{e} 6$ & 16 \\
\hline
\end{tabular}

*Used in the current RELAP5 model

\subsection{Reactor vessel and internals}

A conceptual drawing of the reactor vessel and its internal components, as modeled in RELAP5, is shown in Figure 3. The details of the components were obtained from Ref. [4] as well as notes describing previous RELAP5 models.

The main bodies of the vessel (structures 101 through 105) were modeled as aluminum cylinders where the inner diameters were based on the internal volumes and heights and the outer diameters were specified to conserve the structure volumes ${ }^{2}$. The covers at the top and bottom of the vessel (structure 100 and 106, respectively) were specified as stainless steel with a spherical geometry.

The internal vessel components included the flow diffuser (120), channel supports (140 and 201), the flow guide (202) and the support grid (203 and 220).

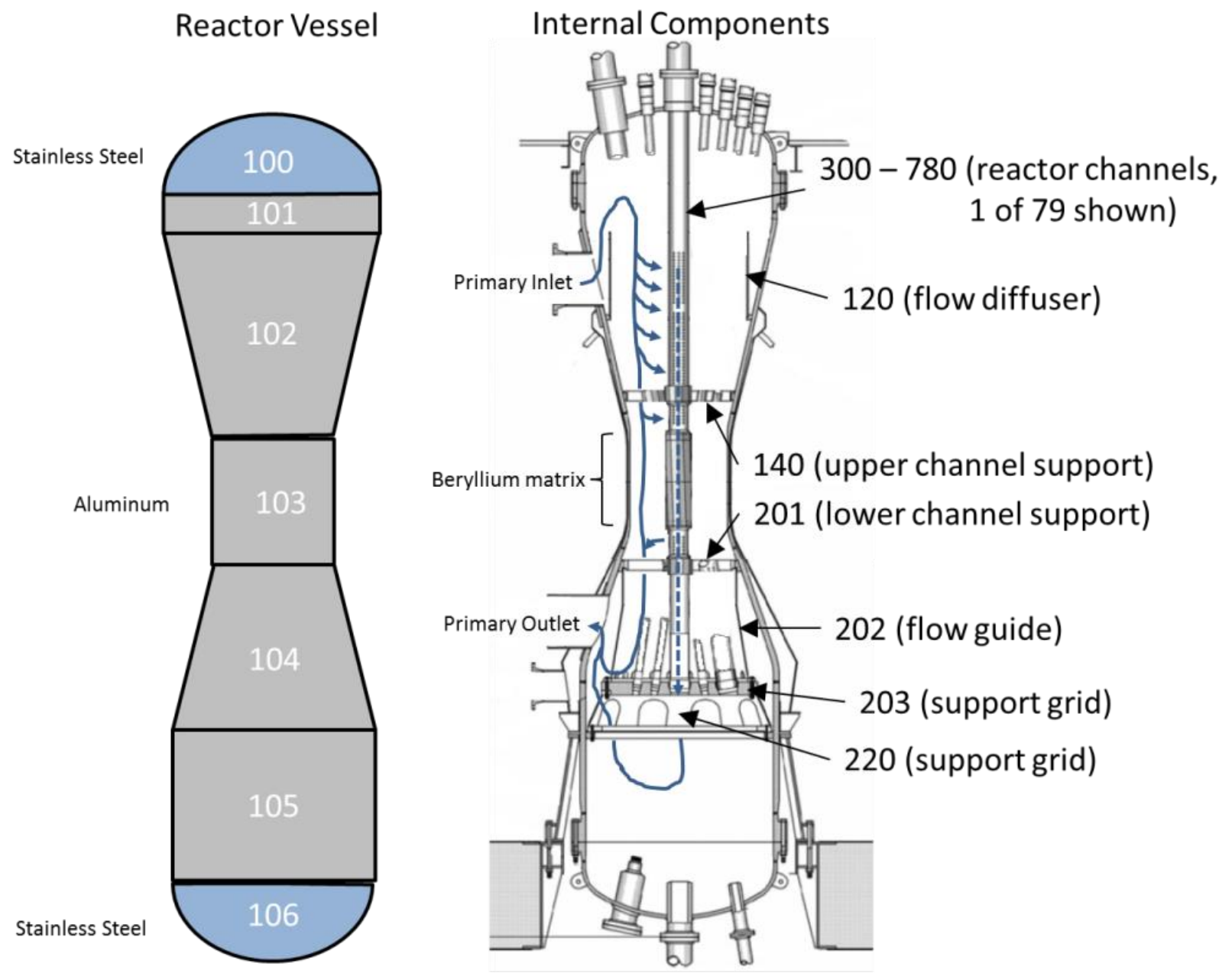

\footnotetext{
${ }^{2}$ The wall thickness of the pressure vessel structures specified in the RELAP5 model will be slightly different than the actual values.
} 


\section{Figure 3 Heat structure numbers in the RELAP5 model of the BR2 reactor vessel and internal structures.}

\subsection{Reactor vessel shroud}

The geometrical data for the pressure vessel outer wall and shroud inner wall were extracted from the figures in Ref. [4] and are plotted here in Figure 4 (the shroud outer wall has not been included in the RELAP5 model). The cooling shroud was described as a single coolant pipe (RELAP5 \#166) discretized into 31 axial volumes (annular cylinders). The discretization was in part to take advantage of the reactors convenient geometrical shapes for creating the model (Figure 4: blue numbers and blue vertical dashes). For example, the total coolant volume for RELAP5 volume 166-1 was determined from volume equations for a cylinder and/or conical frustum utilizing dimensions of the vessel and shroud at that location. The total surface area was determined in a similar manner and the two values were used to obtain a hydraulic diameter (hydraulic diameter $=\frac{\text { volume }}{\text { surface area }}$ ). Although not evident in the figure, there is a flow constriction between the shroud and reactor vessel at junction 4 and 27 . The abrupt area change model was applied at these locations.

The heat structure connections are also shown (Figure 4: red numbers and colored background). For example, the shroud coolant volumes 166-1 and 166-2 are thermally connected to pressure vessel heat structure number 105 . The axial discretization in the core region (i.e. volumes 5-26) was based on the fuel element discretization to simplify thermal connections at that elevation within the model.

A time dependent volume has been placed at each end of the cooling shroud. The outlet pressure was specified as $1.94 \mathrm{e} 5 \mathrm{~Pa}$ and the inlet temperature and flow rate were specified as $33^{\circ} \mathrm{C}$ and $111 \mathrm{~kg} / \mathrm{s}$. 


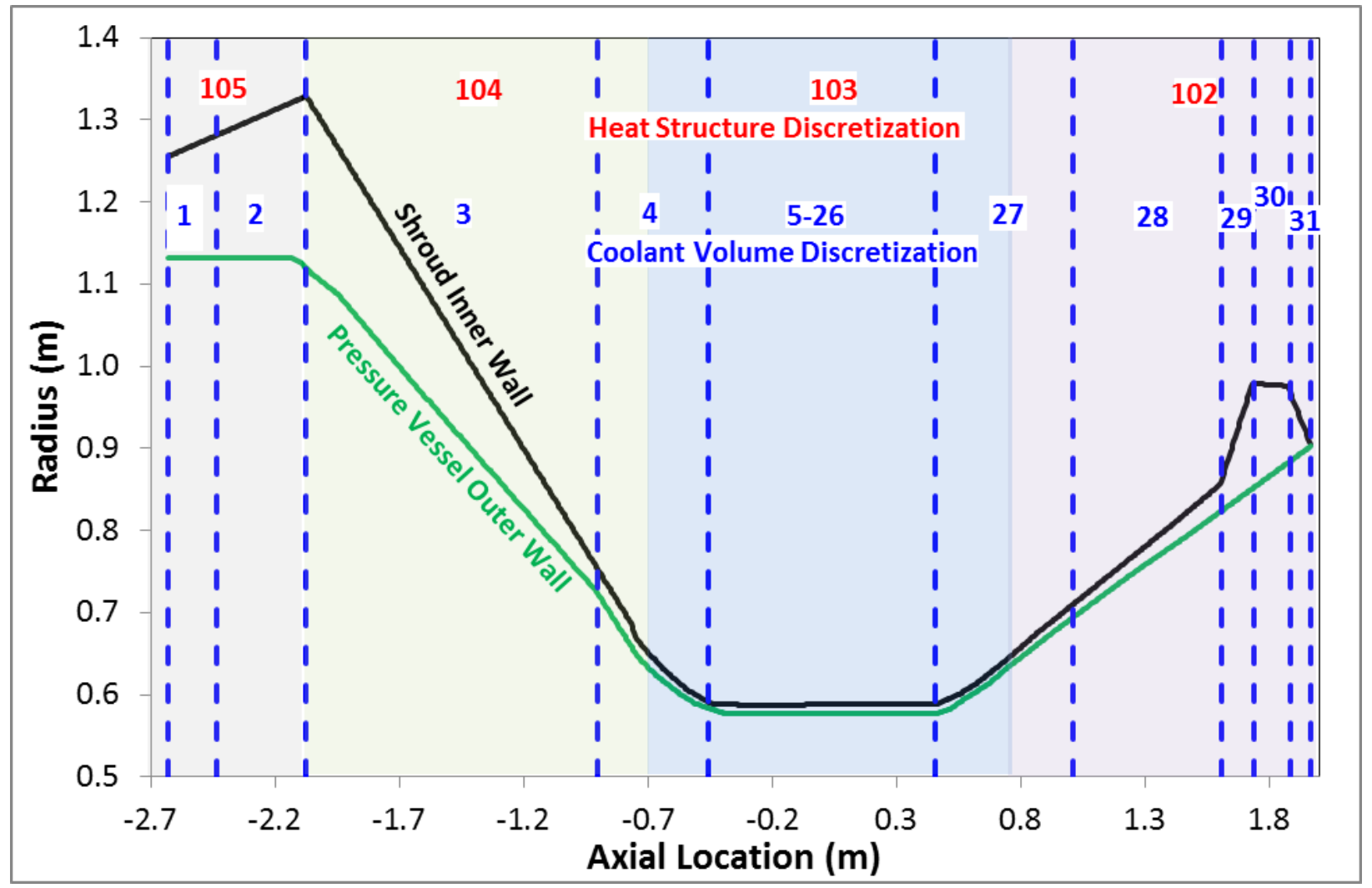

Figure 4 Shroud dimensions and discretization.

\subsection{Reactor channels}

In order to appropriately model the BR2 channels and maintain a simplified RELAP5 model, the 79 channels (80 including the bypass flow) have been consolidated into four representative flow channels (Figure 5); including the bypass flow (volumes 10-20), a single flow channel containing the highest heat flux fuel assembly (volumes 30-40), the remaining fuelled flow channels (volumes 50-60) and all remaining non-fuelled flow channels (volume 70-80). The volume containing the highest heat flux fuel assembly (volume 36) was further discretized (volumes 360, 365, 366, and 367) to better represent individual sub-channels associated with the fuel plates (Figure 6). The geometry was based on the Sylcor VIn fuel assembly used in the 1963 BR2 experiments (Table A-15). Previous work has shown that 3 explicit sub-channels are sufficient to predict the peak cladding temperature in a LOFA simulation [6]. The sub-channels represent only a 10 degree arc of the sector to properly model the azimuthal power peak-to-average ratio. Computational fluid dynamic (CFD) simulations [7] have demonstrated the validity of this approximation for both normal operation and natural circulation since both azimuthal coolant mixing and azimuthal heat conduction in the fuel plate are relatively small. 


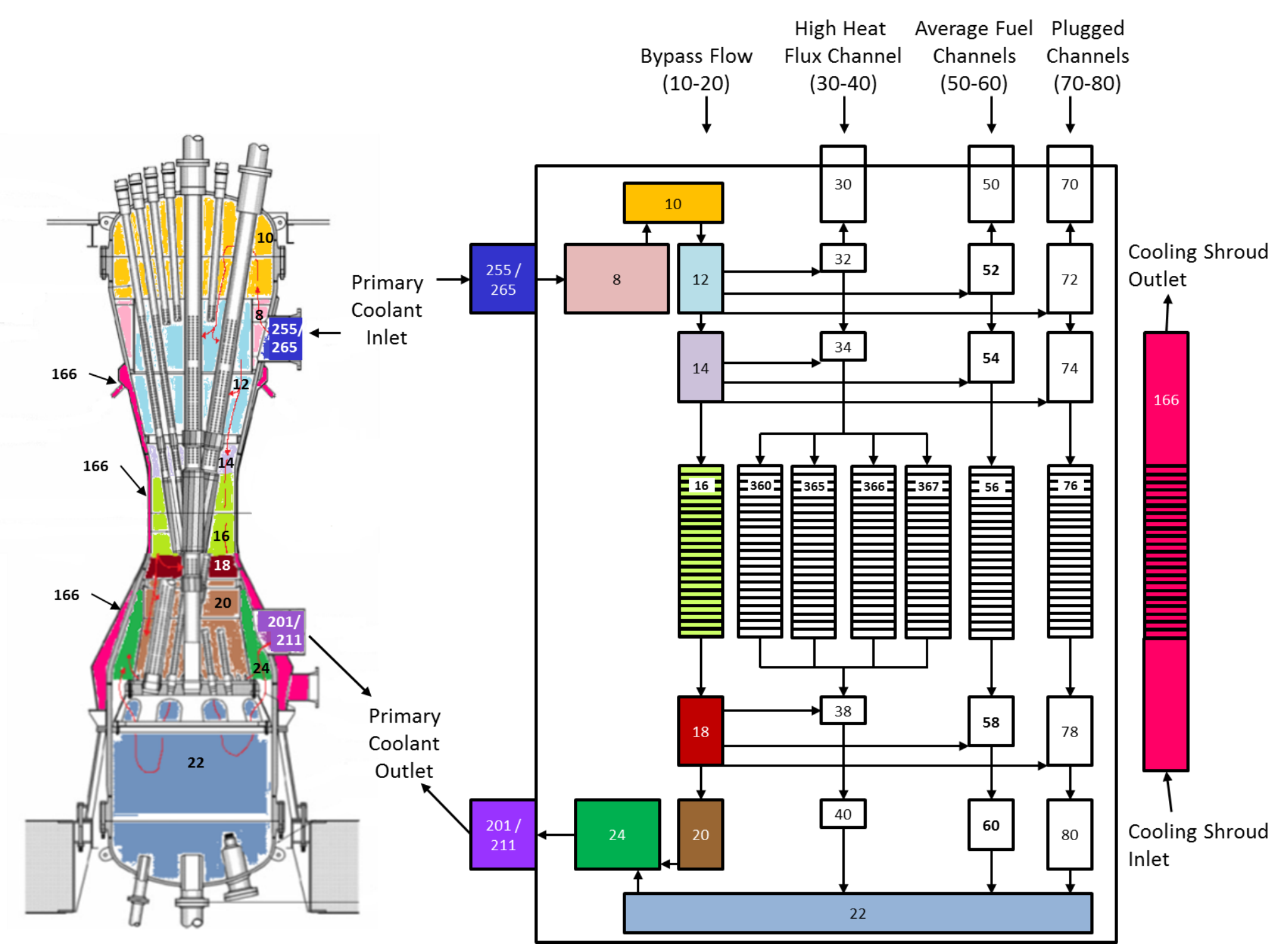

Figure 5 Coolant volume numbers in the RELAP5 model of the BR2 Reactor Vessel. 


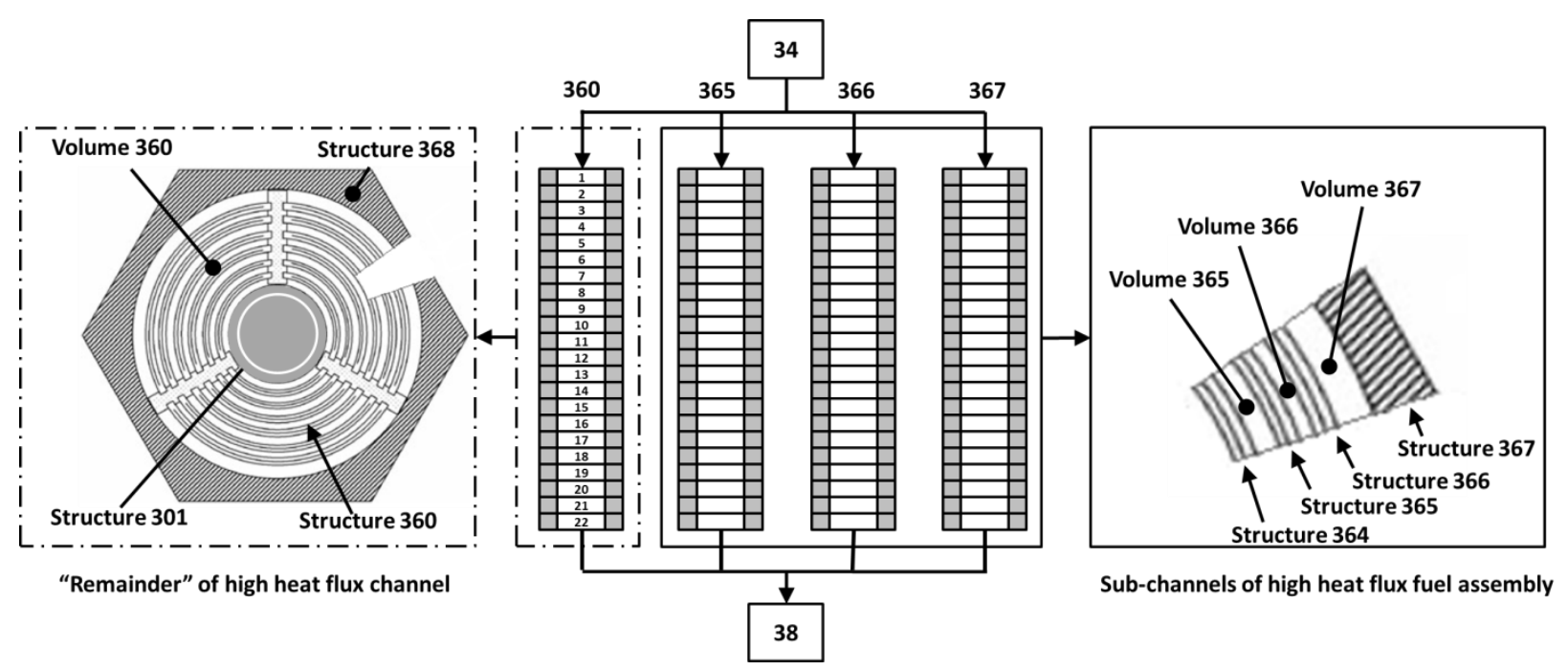

Figure 6 Discretization of the high heat flux Silcor VIn fuel assembly.

The four flow channels have been discretized into six axial sections: one volume for the section of channel located in the upper plenum (Volumes 10, 30, 50 and 70); one volume for the perforated section of channel above the upper channel support (Volumes 12, 32, 52 and 72); one volume for the section of channel above the core but below the upper channel support (Volumes 14, 34, 54 and 74). Within the core region the coolant volumes were described using pipe components and were discretized using the same axial nodalisation as the fuel heat structure as illustrated in Figure 6. That is, 20 segments were used to describe the fuelled region with an additional sub-volume at the top and bottom end to describe the non-fuelled part of the fuel assembly (total of 22 segments). Previous work [6] has shown that this level discretization is sufficient for a mesh independent solution of peak cladding temperatures. Below the core region the channels were split into two regions; one volume between the core and the lower support guide (Volumes 18, 38, 58 and 78) and another for the remainder of the channel (Volumes 20, 40, 60 and 80).

Cross flow occurs between the bypass channel and the other three channels through a number of channel perforations in three different axial regions. The hydraulic diameter of the perforations above the channel supports was $6.35 \mathrm{~mm}$ and the respective flow areas depends on the number of reactor channels associated with each of the RELAP5 channels. The hydraulic diameter of the perforation in the segment just above the core was $4.76 \mathrm{~mm}$ in the fuelled section. The hydraulic diameter for the plugged channel perforations in the 1963 experiments was $5.56 \mathrm{~mm}$ but is dependent on the core configuration since the value is determined from a consolidation of different channel types with different number of perforations and diameters.

Form loss coefficients and the abrupt area change model were included at various locations of the model and are described in detail in Appendix B.

As described earlier, the channels form a hyperboloid configuration where only the center channel is vertical and the off axis angle increases to $\sim 10$ degrees at the outermost channels. For simplicity, each of the channels has been modeled as vertical. This was done for two reasons. First, if the angles were included, updating the model for different core configurations requires updating almost all of the 
RELAP5 parameters that make up the channel volumes and heat structures. Modeling the channels vertically significantly limits the parameters that must be updated and reduces the likelihood for error in transcribing parameters. Second, the small offset from vertical does not influence the heat transfer or flow regime models used within RELAP5. The only impact is the small discrepancy between actual and projected lengths of components within each axial region, which is not expected to significantly affect simulation results.

The heat structures describing the channels outside the core region were modeled as stainless steel cylinders with their respective inner and outer diameter. The geometry for the hexagonal part of the channels within the core was based on the bore diameter of the channel. The outer diameter was based on a tube thickness that resulted in the same volume of channel material. The components inside the channels were modeled as two cylinders with the outer diameter chosen to conserve beryllium and aluminum volumes, respectively. The fuelled channels contained a single plate structure to represent the fuel element. As shown in Figure 6, the high heat flux channel contained four plate structures to capture the local power peaking.

\subsection{BR2 primary system (inside the pool)}

The RELAP5 model describing the section of primary piping located between the isolation valves and reactor vessel (Figure 7) has been updated and documented separately by the BR2 team [3]. The only modification used in the model described here was the replacement of junction 294 with a valve describing the pool connection valve (ABV4-1308). The pool connection valve was connected to a time dependent volume (100) that represents the pool (infinite energy sink). Heat structures in contact with the pool were also thermally connected to this time dependent volume. The fluid conditions for the pool were specified as $1.94 \mathrm{e} 5 \mathrm{~Pa}$ and $25^{\circ} \mathrm{C}$. 


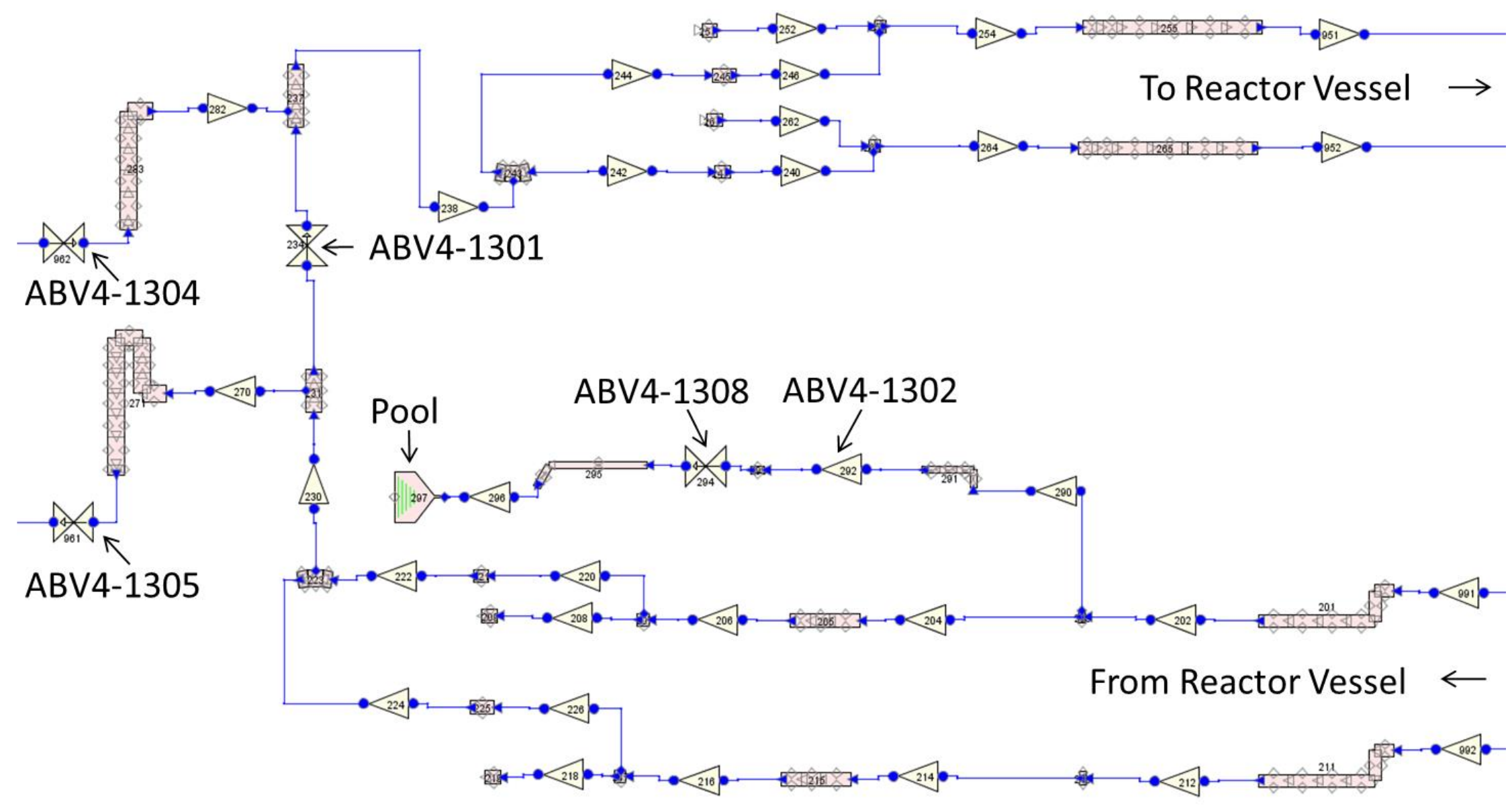

Figure 7 RELAP5 model of the BR2 primary system located inside the pool. 


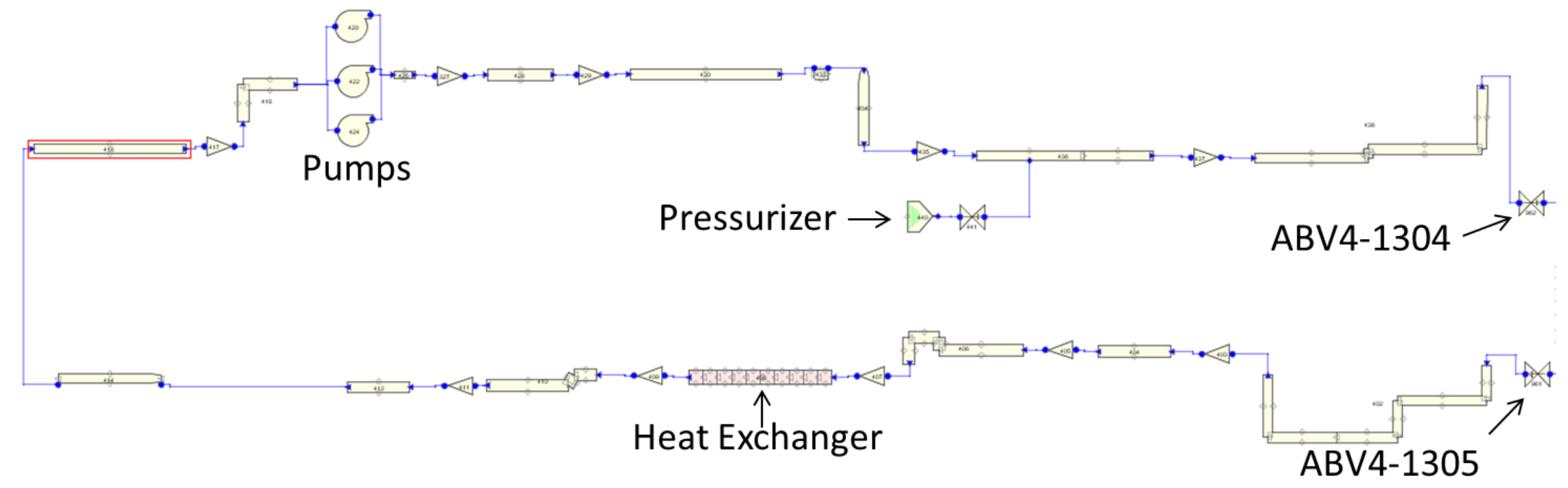

Figure 8 RELAP5 model of the BR2 primary system located outside the pool. 


\subsection{BR2 primary system (outside the pool)}

\subsubsection{Primary piping}

The BR2 primary system is shown in Error! Reference source not found.. The piping and components ssociated with the backup pump system has not been included in the current model since it does not significantly contribute to the simulations. The remainder of the piping has remained unchanged from previous RELAP5 models. Also, as in previous models, heat structures have not been defined for components outside the reactor pool (except for the heat exchanger).

\subsubsection{Heat exchanger}

The primary heat exchanger system utilized during the 1963 experiments consisted of three parallel banks each containing three heat exchangers. The rated values for a bank of heat exchangers were provided in Chapter 9.8 of the BLG 59 report [8] and are summarized here in Table 2. The values represent a significant change from the heat exchanger model provided in previous RELAP5 models ${ }^{3}$.

Table 2 Heat exchanger rated values, per bank [8].

\begin{tabular}{|c|c|}
\hline Flow rate $\left[\mathrm{m}^{3} / \mathrm{min}\right]$ and $[\mathrm{kg} / \mathrm{s}]$ & $35 / 581$ \\
\hline Tube length [m] & 11.75 \\
\hline Surface Area $\left[\mathrm{m}^{2}\right]$ & 1053 \\
\hline Velocity $[\mathrm{m} / \mathrm{s}]$ & 2 \\
\hline Pressure drop [Pa] & 98066.5 \\
\hline \multicolumn{2}{|c|}{ Calculated values based on above info } \\
\hline Number of tubes & 2191 \\
\hline Average tube diameter [m] & 0.01302 \\
\hline Flow area $\left[\mathrm{m}^{2}\right]$ & 0.2917 \\
\hline
\end{tabular}

A minor loss coefficient value of 5.7 was added to the inlet and outlet heat exchanger junctions to match the rated pressure drop.

The secondary side of the heat exchanger was modeled with a constant heat transfer coefficient $\left(1 \mathrm{e} 9 \mathrm{~W} / \mathrm{m}^{2}-\mathrm{K}\right)$ and bulk temperature $(306.22 \mathrm{~K})$ boundary condition. These values produce inlet coolant temperature in the range of $36^{\circ} \mathrm{C}-38^{\circ} \mathrm{C}$ for simulations of tests $\mathrm{A}, \mathrm{C}$ and $\mathrm{F}$.

\subsubsection{Primary Pump}

The BR2 primary system contains three main pumps operating in parallel. Their specifications were provided in chapter 9.2.1.1 of BLG 59 [8] and are summarized here in Table 3.

Table 3 Parameters for the BR2 main pumps.

\begin{tabular}{|l|c|c|}
\hline Parameter & Rated Value [8] & RELAP5 Value \\
\hline Speed & $1430[$ RPM] & $149.75[\mathrm{rad} / \mathrm{s}]$ \\
\hline Flow & $35\left[\mathrm{~m}^{3} / \mathrm{m}\right]$ & $0.5833\left[\mathrm{~m}^{3} / \mathrm{s}\right]$ \\
\hline Head & $76.2[\mathrm{~m}]$ & $76.2[\mathrm{~m}]$ \\
\hline Torque & $2754[\mathrm{lbf}-\mathrm{ft}]$ & $3734.6[\mathrm{~N}-\mathrm{m}]$ \\
\hline Moment of Inertia & $230\left[\mathrm{~kg}-\mathrm{m}^{2}\right]$ & $230\left[\mathrm{~kg}-\mathrm{m}^{2}\right]$ \\
\hline
\end{tabular}

\footnotetext{
${ }^{3}$ It is possible that the heat exchanger model used in previous RELAP5 models was based on the heat exchanger system implemented in 1971, although this has yet to be confirmed.
} 
The RELAP5 model includes three identical pumps $(413,414$ and 415$)$ with the specifications given in Table 3. The homologous curves for the BR2 pumps (Figure 9) were obtained from previous RELAP5 models and are based on the pump manufactures data. As can be seen from the figures, a discontinuity exists between flow regimes for several instances (likely due to lack of data points). This is not an issue for the current LOFA simulations as the pump remains in the normal operating mode. A proportionalintegral ( $\mathrm{PI}$ ) control block was used to set the pump speed to obtain the target flow rate within the primary system at steady-state conditions. For accident conditions where the pump has been tripped, flow is controlled by the hydraulic resistance of the reactor, the homologous curves and the torque friction described in section 3.2.1.

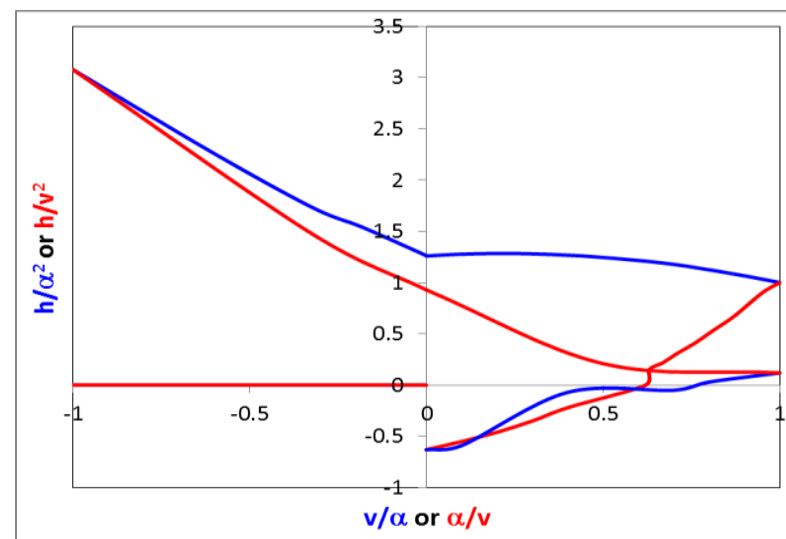

(a)

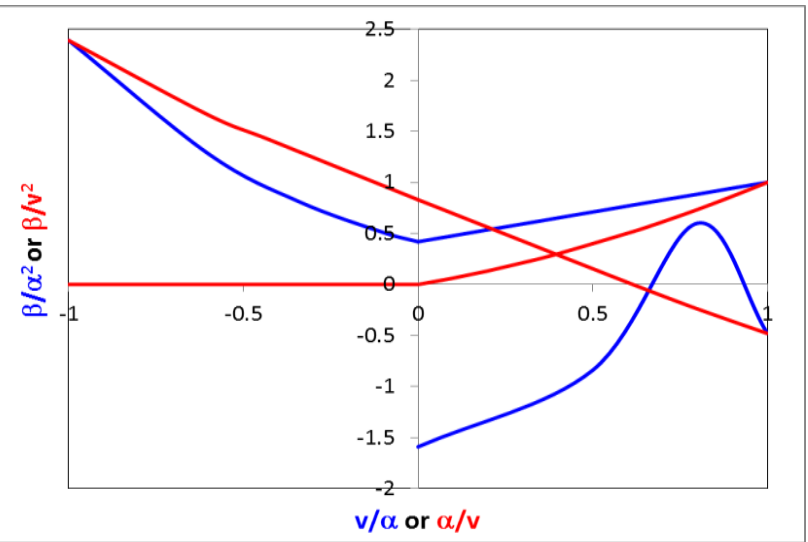

(b)

Figure 9 Homologous curves for the BR2 main pumps; (a) head, (b) torque. ${ }^{4}$

\subsubsection{Pressurizer}

The pressurizer was modeled as a time dependent volume (150) and servo valve (102) connected to junction 1 of pipe 504 with a cross-flow connection. A PI control block (CB 2051, 2052 and 2053) was used to set the pressurizer pressure to obtain the target pressure at the same location as the BR2 measured inlet pressure (volume 1 of pipe 253). A control block (CB 2054) was also used to isolate the pressurizer for loss of pressure simulations.

\section{Model Calibration}

\subsection{Reactor Vessel}

Calibration of the RELAP5 vessel model was performed to ensure that the calculated pressure losses and flow distributions were in agreement with known reactor performance. A significant amount of data was available for calibration for a variety of core configurations in both BR2 and a hydraulic mock-up facility. The hydraulic experiments performed in BR2 in 1962 supplied the primary data for model calibration. Calibration of pressure losses across the RELAP5 vessel model can be separated into five relevant sections; the inlet piping to the upper plenum, the upper plenum to the upper core matrix, across the core matrix, below the core matrix to the lower support grid and from the lower support grid

${ }^{4} \alpha=$ rotational ratio; $v=$ volumetric flow ratio; $h=$ head ratio; and $\beta=$ torque ratio. 
to the outlet piping (Figure 10). Precisely modeling the BR2 pressure losses is extremely difficult due to numerous flow paths but relatively coarse distribution of pressure measurements. The pressure at any given axial location can vary depending on its proximity to channels of varying velocities, and hence pressures. For example, between the core and upper channel support, the coolant in the fuel channels has a relatively high velocity and low pressure which results in a cross flow from the bypass into the channels. The opposite is true for plugged channels where the net cross flow is from the channels to the bypass [9]. The calibration strategy employed was to first calibrate the known flow distribution and pressure drop in the core region. Following this, additional loss coefficients outside the core were applied in way that resulted in the correct global pressure loss but maintained the same flow distribution across all channels. In other words, the form loss coefficients calculated in Appendix B and implemented in RELAP5 were assumed to already provide a reasonable approximation to the flow distribution; only the magnitude of pressure loss was adjusted. This was considered sufficient since the local pressure losses and flow distributions were not known outside the core region.

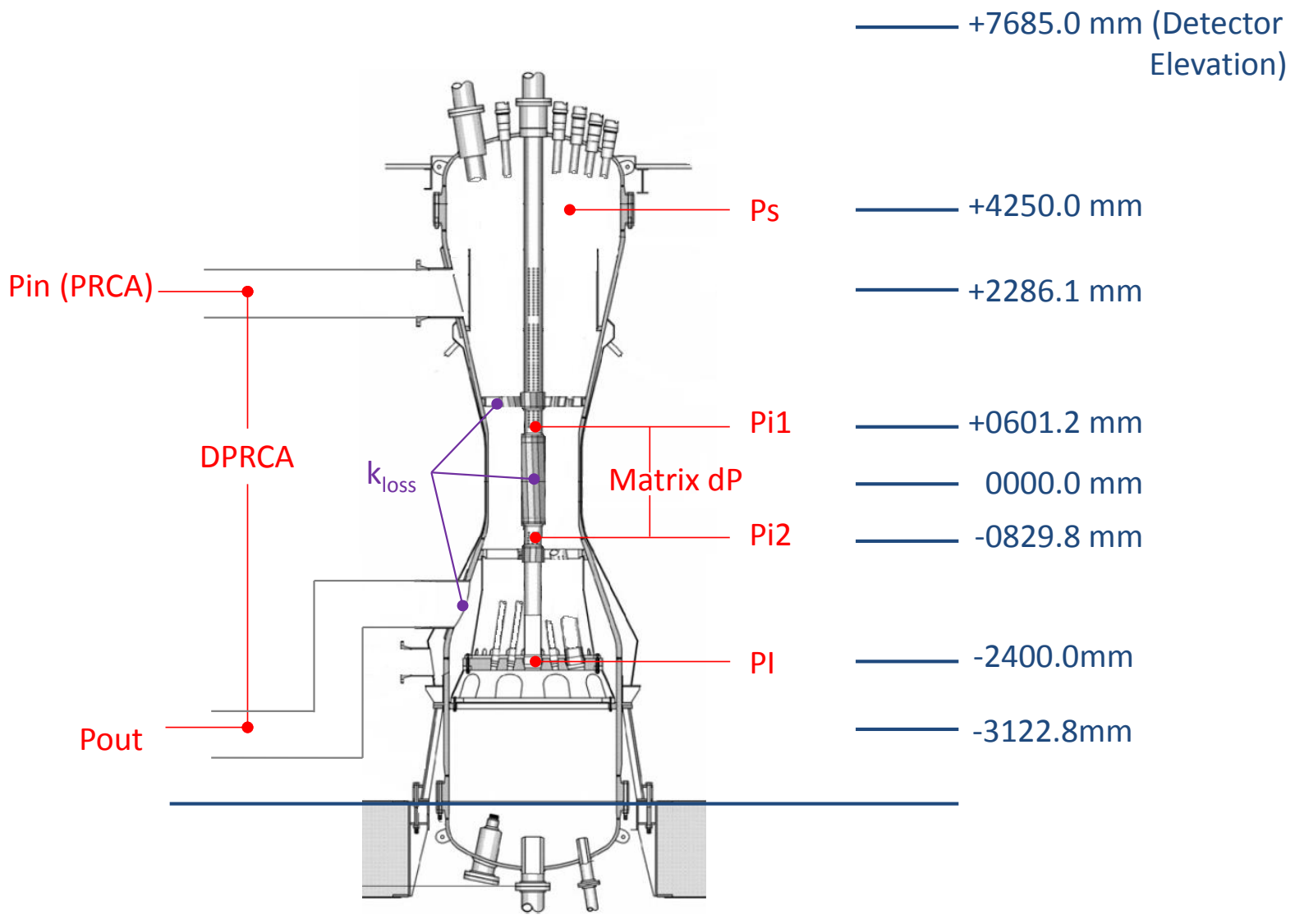

Figure 10 Location and elevation of pressure measurements. Also shown are the three locations where additional loss factors were applied to match reactor data. 


\subsubsection{Calibration inside the core}

Tests performed in a hydraulic mockup facility contained data for the flow distribution between the bypass, fuel, control rod and plugged channels for eight different core configurations at an average flow rate of $2200 \mathrm{l} / \mathrm{min}$ within a fuel element ${ }^{5}$ [10]. Reference [10] provided a detailed description of the coolant as it flows through various paths within the BR2 vessel and used detailed calculations to explain the direction of flow and predict the axial pressure distributions. This information was used in the development of an experimental program for measuring pressure distributions within BR2 (designated as the 1962 experiments). This reference also provided these experimental results for different total flow rates and core loadings of 3, 6, 14, 17, and 24 fuel elements (the remainder of the core included beryllium plugs). Highlights from these and other experimental results were summarized in Reference [9] and Table 4 for a pressure drop of $2.1 \mathrm{~kg} / \mathrm{cm}^{2}$ across the core.

Table 4 Summary of flow rates for a given channel type.

\begin{tabular}{|l|l|c|c|}
\hline \multicolumn{1}{|c|}{ Channel Type } & \multicolumn{1}{|c|}{ Channel Contents } & \multicolumn{2}{c|}{ Flow Rate } \\
\hline \multirow{3}{*}{ Standard channel $(84 \mathrm{~mm})$} & with beryllium plug & $256 \mathrm{I} / \mathrm{min}$ & $4.3 \mathrm{~kg} / \mathrm{s}$ \\
\cline { 2 - 4 } & with fuel element type VIn & $2140 \mathrm{I} / \mathrm{min}$ & $35.6 \mathrm{~kg} / \mathrm{s}$ \\
\cline { 2 - 4 } & with control rod & $442 \mathrm{I} / \mathrm{min}$ & $7.3 \mathrm{~kg} / \mathrm{s}$ \\
\hline H Channel $(200 \mathrm{~mm})$ & with beryllium plug & $1352 \mathrm{I} / \mathrm{min}$ & $22.5 \mathrm{~kg} / \mathrm{s}$ \\
\hline Reflector Channel $(50 \mathrm{~mm})$ & with beryllium plug & $135 \mathrm{I} / \mathrm{min}$ & $2.2 \mathrm{~kg} / \mathrm{s}$ \\
\hline
\end{tabular}

Of note is that Ref. [9] and [10] do not provide a reference flow rate for the bypass channel. It was reported in [10], that for nominal conditions, the flow rate in BR2 was measurably larger than the hydraulic facility $(1261 \mathrm{~kg} / \mathrm{s}$ compared to $1166 \mathrm{~kg} / \mathrm{s})$. The reasons for this were attributed to dimensional tolerance, surface roughness and differences in the diameter, distance and number of holes in the upper extension tubes [10]. Based on the reported information it seems that this discrepancy in total flow has been attributed to the bypass flow. For the hydraulic facility, the bypass flow was reported as 227.2 $\mathrm{kg} / \mathrm{s}$ for all core configurations. The bypass flow for the BR2 1962 tests of different core configurations was estimated to be $361.6 \pm 26.7 \mathrm{~kg} / \mathrm{s}$ based on the difference between total measured flow and the sum of what was expected for each channel type at nominal flow conditions.

Calibration of the core in the RELAP5 vessel model was accomplished by adding forward loss coefficients in channels 16, 360, 365, 366, 367, 56 and 76 so that the flow distributions and pressure drop matched those of nominal conditions. The reverse loss coefficients were assumed to be identical.

The following steps were followed in this calibration process: first, the RELAP5 model was run with the minor loss coefficients set to zero to establish the pressure losses within the core region, the pressure losses into and out of the core region, and the channel flow rates. The channel mass flow rates and their respective pressure losses were then used as input to a separate core hydraulic model based on steady state equations (designated as the EES model). This EES model contains pressure loss equations to describe friction losses within the core channels and two additional loss coefficients. Of these later two, the first is used to match the EES model results to the RELAP5 results without minor loss

${ }^{5}$ Private communication with BR2 engineers indicates there was a discrepancy in the reported bypass flow (14000 $\mathrm{l} / \mathrm{min}$ versus $13360 \mathrm{l} / \mathrm{min})$. The correct value is $13360 \mathrm{l} / \mathrm{min}$. 
coefficients and the second is used to determine the loss coefficients needed to match both models to the BR2 1962 data. The loss coefficient needed to match the EES model to the RELAP5 results was small in value and mainly accounts for differences between friction factor models. For example, RELAP5 uses the Colebrook relation [11] for determining the friction factor while the EES model uses its built-in Churchill relation [12]. With the channel inlet and outlet pressures and flow distribution results from the RELAP5 model input into the EES model, the first of the two additional loss coefficients was determined; putting the two models in exact agreement regarding pressure losses and mass flow rates for each channel. Next, the target mass flow rates and pressure drop data were input into the EES model and the equations were solved to determine the second of the required loss coefficients. These loss coefficients were evenly distributed across the 21 internal junctions for each of the core volumes (i.e. within volumes $16,360-367,56,76$ ). The RELAP5 model was then run again to verify the correct pressure drop and mass flow distribution were correct.

In reality, the pressure losses for each channel type are not actually identical nor are they known a priori. In determining the loss coefficients needed to reproduce the experimentally measured flow rates, an average pressure drop across the core was used as a reference in preliminary calculations. By itself, the predetermined loss coefficients were only accurate enough to achieve $+/-4 \%$ agreement between the RELAP5 flow rates and the experimentally measured values. To improve upon this, the ratio of the individual channel pressure drop and average channel pressure drop from the first RELAP5 simulations were imposed on the respective channels in the second EES calculation to achieve an approximation to the expected differences in pressure drop. In this case, the target pressure drop of $2.1 \mathrm{~kg} / \mathrm{cm}^{2}$ was imposed on the high heat flux channel while the other channels were slightly above or below this value (as predicted by RELAP5). This approach resulted in improving the flow rate accuracy to better than $+/-1 \%$ for all channels.

Core calibration results for the 3,14 and 24 element core configurations of the 1962 experiments are given in Table 5. The correct flow rates for each channel were obtained. It is also important to point out that the loss coefficient for a given channel is independent of the core configuration, except for volume 16. This is in agreement with test results that show that for nominal conditions the flow rate of each channel is independent of the core configuration. The loss coefficient of volume 16 varies significantly since, as stated earlier, this channel contains all of the flow uncertainty. 
Table 5 Loss coefficients determined for a 3, 14 and 24 element core. The average values are also given.

\begin{tabular}{|c|c|c|c|c|c|}
\hline \multirow{10}{*}{$\begin{array}{l}1962 \text { BR2 test with } 3 \\
\text { fuel elements }\end{array}$} & \multirow[t]{2}{*}{$\begin{array}{c}\text { RELAP5 } \\
\#\end{array}$} & $\begin{array}{c}\text { Estimated } \\
\text { k_loss }\end{array}$ & $\begin{array}{c}\text { Target } \\
\text { flow }\end{array}$ & $\begin{array}{l}\text { Calculated } \\
\text { flow } \\
\end{array}$ & $\begin{array}{c}\% \\
\text { Difference }\end{array}$ \\
\hline & & {$[-]$} & {$[\mathrm{kg} / \mathrm{s}]$} & {$[\mathrm{kg} / \mathrm{s}]$} & [\%] \\
\hline & 16 & 2.256 & 380.4 & 381.7 & +0.34 \\
\hline & 360 & 0.4829 & 35.09 & 35.23 & +0.39 \\
\hline & 365 & 0.7081 & 0.1681 & 0.1689 & +0.48 \\
\hline & 366 & 0.7200 & 0.1915 & 0.1924 & +0.47 \\
\hline & 367 & 1.2720 & 0.2531 & 0.2549 & +0.71 \\
\hline & 36 & & 35.7 & 35.8 & +0.42 \\
\hline & 56 & 0.5202 & 71.3 & 71.7 & +0.56 \\
\hline & 76 & 3.8200 & 395.4 & 393.6 & -0.46 \\
\hline \multirow{10}{*}{$\begin{array}{l}1962 \text { BR2 test with } 14 \\
\text { fuel elements }\end{array}$} & \multirow[t]{2}{*}{$\begin{array}{c}\text { RELAP5 } \\
\quad \#\end{array}$} & $\begin{array}{l}\text { Estimated } \\
\text { k_loss }\end{array}$ & $\begin{array}{l}\text { Target } \\
\text { flow }\end{array}$ & $\begin{array}{l}\text { Calculated } \\
\text { flow }\end{array}$ & $\begin{array}{c}\% \\
\text { Difference }\end{array}$ \\
\hline & & {$[-]$} & {$[\mathrm{kg} / \mathrm{s}]$} & {$[\mathrm{kg} / \mathrm{s}]$} & [\%] \\
\hline & 16 & 4.001 & 324.4 & 325.8 & +0.43 \\
\hline & 360 & 0.4794 & 35.09 & 35.14 & +0.14 \\
\hline & 365 & 0.7048 & 0.1681 & 0.1684 & +0.18 \\
\hline & 366 & 0.7168 & 0.1915 & 0.1919 & +0.21 \\
\hline & 367 & 1.2690 & 0.2531 & 0.2542 & +0.43 \\
\hline & 36 & & 35.7 & 35.8 & +0.15 \\
\hline & 56 & 0.5075 & 463.7 & 464.8 & +0.24 \\
\hline & 76 & 3.72 & 348.5 & 345.6 & -0.83 \\
\hline \multirow{10}{*}{$\begin{array}{l}1962 \text { BR2 test with } 24 \\
\text { fuel elements }\end{array}$} & \multirow[t]{2}{*}{$\begin{array}{c}\text { RELAP5 } \\
\#\end{array}$} & $\begin{array}{c}\text { Estimated } \\
\text { k_loss }\end{array}$ & $\begin{array}{l}\text { Target } \\
\text { flow }\end{array}$ & $\begin{array}{l}\text { Calculated } \\
\text { flow }\end{array}$ & $\begin{array}{c}\% \\
\text { Difference }\end{array}$ \\
\hline & & {$[-]$} & {$[\mathrm{kg} / \mathrm{s}]$} & {$[\mathrm{kg} / \mathrm{s}]$} & [\%] \\
\hline & 16 & 2.614 & 395.5 & 395.8 & +0.08 \\
\hline & 360 & 0.4733 & 35.09 & 35.16 & +0.20 \\
\hline & 365 & 0.6979 & 0.1681 & 0.1686 & +0.30 \\
\hline & 366 & 0.7099 & 0.1915 & 0.1920 & +0.26 \\
\hline & 367 & 1.2630 & 0.2531 & 0.2544 & +0.51 \\
\hline & 36 & & 35.7 & 35.8 & +0.21 \\
\hline & 56 & 0.4973 & 820.3 & 822.6 & +0.28 \\
\hline & 76 & 4.200 & 305.8 & 303.2 & -0.85 \\
\hline \multirow{8}{*}{ Average and deviation } & $\begin{array}{c}\text { RELAP5 } \\
\#\end{array}$ & \multicolumn{2}{|c|}{ k_loss } & \multirow{8}{*}{\multicolumn{2}{|c|}{$\begin{array}{l}\text { Input to achieve } \\
\text { measured pressure drop } \\
\text { and assumed flow } \\
\text { distribution }\end{array}$}} \\
\hline & 16 & \multicolumn{2}{|c|}{$2.9570 \pm 0.753$} & & \\
\hline & 360 & \multirow{2}{*}{\multicolumn{2}{|c|}{$\frac{0.4785 \pm 0.004}{0.7036 \pm 0.004}$}} & & \\
\hline & 365 & & & & \\
\hline & 366 & \multicolumn{2}{|c|}{$0.7156 \pm 0.004$} & & \\
\hline & 367 & \multicolumn{2}{|c|}{$1.2680 \pm 0.004$} & & \\
\hline & 56 & \multicolumn{2}{|c|}{$0.5083 \pm 0.009$} & & \\
\hline & 76 & \multicolumn{2}{|c|}{$3.9130 \pm 0.206$} & & \\
\hline
\end{tabular}


It is also important to note that the loss coefficient in volume 76 (plugged channel) does not vary significantly for the 1962 core configurations since the hydraulic diameter and velocity remain essentially constant since all the channels contain identical plugs. Figure 11 illustrates the loss coefficient trend for the BR2 and hydraulic facility flow experiments, the 1963 BR2 core and the hypothetical representative core. However, in the RELAP5 model of the representative core, the minor loss coefficients for the plugged channel (volume 76) can change with core configuration since it is an approximation to a number of different channel types (e.g. plug, experimental apparatus, control rod, etc.) which, depending on the number of each type, can alter the hydraulic diameter and cross sectional flow area. Here it was useful to also analyze several core configurations from the hydraulic facility since it helps bridge the gap between the 1962 data and the representative core.

While Figure 11 shows the trend of required minor loss coefficient ( $k$ ) as a function of hydraulic diameter, it was assumed to be governed by the following Darcy-Weisbach equation ${ }^{6}$ :

$$
k=\frac{C 1}{\left(\frac{\dot{m}}{1000 \cdot A}\right)^{2}}-\frac{C 2}{D_{h}} ; C_{1}=487.4 \text { and } C_{2}=21.93
$$

where the coefficients $C_{1}$ and $C_{2}$ have been optimized with the 1962 core configuration data and the hydraulic facility data. For the representative core, the required minor loss coefficient for volume 76 was calculated to be $17.5\left(\dot{m}=305 \mathrm{~kg} / \mathrm{s}, \mathrm{A}=0.06241 \mathrm{~m}^{2}\right.$ and $\left.D_{h}=0.072 \mathrm{~m}\right)$. Table 6 summarizes the minor loss coefficients of volume 76 for various core configurations.

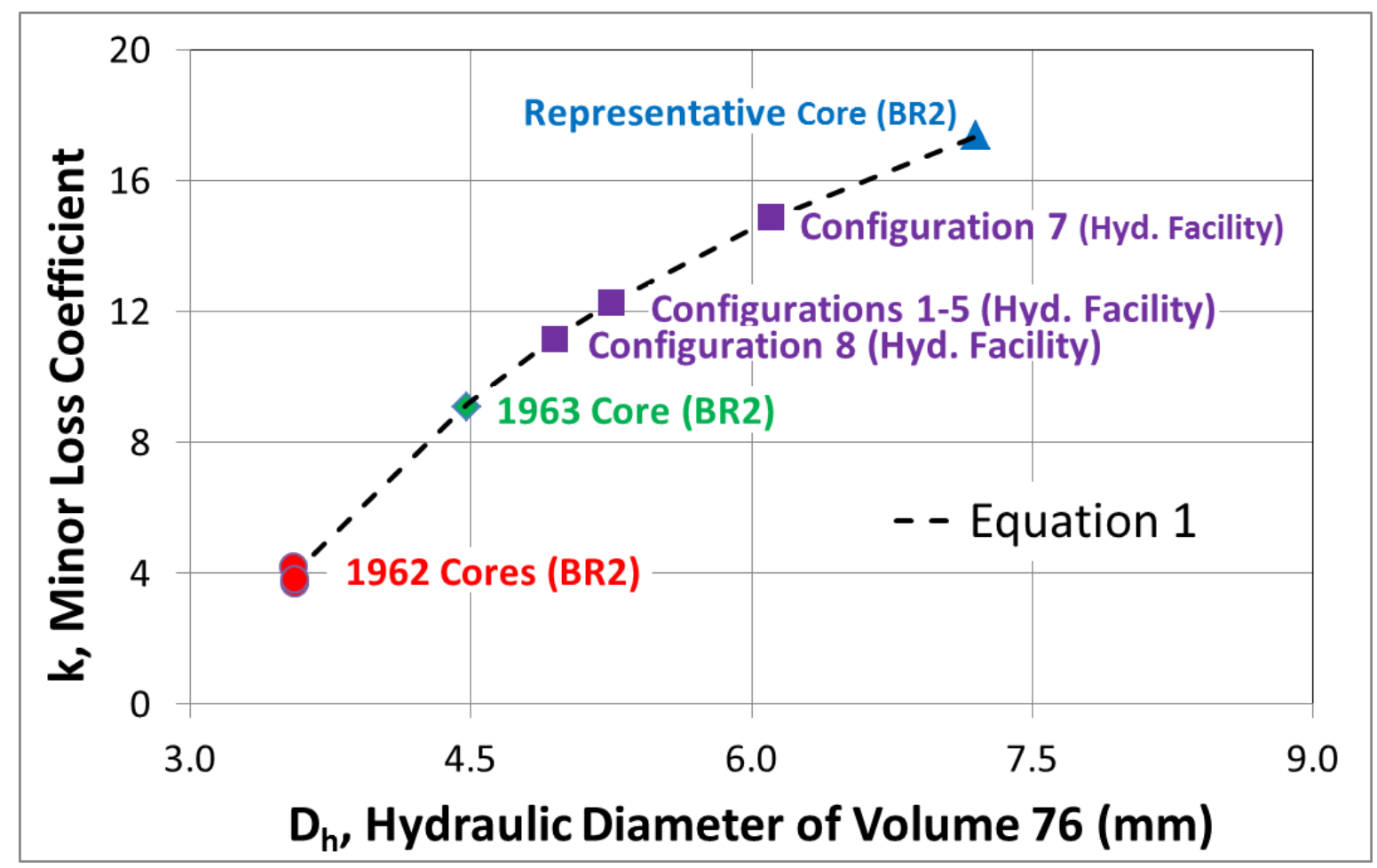

Figure 11 Loss coefficients for volume 76 as a function of various core configurations.

${ }^{6} \mathrm{~A}=$ cross sectional flow area. $\mathrm{D}_{\mathrm{h}}=$ hydraulic diameter. $\dot{m}=$ mass flow rate. 
Table 6 Minor loss coefficient and parameters for volume 76 with various core configurations.

\begin{tabular}{|l|c|c|c|c|c|}
\hline & Mass & Flow & Hydraulic & \multicolumn{2}{c|}{ Minor Loss Coefficient } \\
\cline { 5 - 6 } & Flow Rate & Area & Diameter & Calibration & Equation 1 \\
\cline { 2 - 3 } Core Configuration & $\mathbf{k g} / \mathbf{s}$ & $\mathbf{m}^{\mathbf{2}}$ & $\mathbf{m}$ & - & - \\
\hline 1962,24 fuel assemblies & 305.8 & 0.04368 & 3.55 & 4.20 & 3.77 \\
\hline 1962,14 fuel assemblies & 348.5 & 0.05011 & 3.56 & 3.72 & 3.92 \\
\hline 1962,3 fuel assemblies & 395.4 & 0.05719 & 3.56 & 3.82 & 4.04 \\
\hline Hydraulic facility (Configuration 8) & 433.7 & 0.07767 & 4.95 & 11.15 & 11.20 \\
\hline Hydraulic facility (Configuration 1-5) & 377.2 & 0.06931 & 5.25 & 12.26 & 12.28 \\
\hline Hydraulic facility (Configuration 7) & 290.2 & 0.05644 & 6.1 & 14.89 & 14.84 \\
\hline \hline 1963, 15 fuel assemblies & 376.4 & 0.06394 & 4.48 & & 9.17 \\
\hline Representative, 31 fuel assemblies & 305 & 0.06241 & 7.2 & & 17.36 \\
\hline
\end{tabular}

\subsubsection{Calibration outside the core}

The form loss coefficients included in the RELAP5 model prior to beginning the calibration process were assumed to provide a reasonable approximation of the flow distribution. This was evident in the fact that the RELAP5 simulations without the loss coefficients from the previous section didn't produce a flow distribution pattern that was significantly different from the measured data. After including the loss coefficient from the previous section, it was assumed the flow distribution was finalized and the only modification still required was the magnitude of the pressure drop outside the core region to match it to the BR2 DPRCA measurement. The DPRCA is a differential pressure measurement of the reactor vessel, with pressure taps located on the inlet and outlet piping. Additional pressure measurements are made in the upper plenum and near the lower plenum at the support grid. Review of the available data indicates there is general agreement in pressure loss trends for the 1962 BR2 flow tests, so for simplicity the 14 element core configuration was chosen as the basis for analysis. The loss coefficients were then demonstrated to be applicable to any core configuration over the range of data available for the 1962 BR2 hydraulic tests.

Based on the available data and notes from the BR2 team, the pressure loss from the inlet pipe to the upper plenum and from the core outlet to the support grid was approximately $\sim 0 \mathrm{~kg} / \mathrm{cm}^{2}$. This is due the fact that the flow is decelerating, converting kinetic energy to potential energy. This is in agreement with preliminary RELAP5 simulations. No additional loss factors were required at these locations.

Between the upper plenum and the core inlet, preliminary RELAP5 simulations indicate additional losses were required to match experimental data. A loss coefficient was placed at the junction between volume 12 and 14, as well as for the other channels at this elevation. Similar to the procedure for calibration of the core region, a separate steady-state set of equations were developed to solve for the minor loss coefficient required to match the target pressure drop. Although in this case, the pressure drop was achieved without altering the flow distribution. Table 7 summarizes the loss coefficients required at this location. 
Table 7 Loss coefficients included in reactor vessel model above the core region.

\begin{tabular}{|c|c|c|}
\hline RELAP5 Junction & Additional k loss & Description \\
\hline $\begin{array}{c}\text { Branch \#14, Junction \#1 } \\
\text { between volumes 12 and 14 }\end{array}$ & 2.34 & \multirow{2}{*}{$\begin{array}{c}\text { Input to achieve measured pressure } \\
\text { drop across upper guide plate }\end{array}$} \\
$\begin{array}{c}\text { Branch \#34, Junction \#1 } \\
\text { between volumes \#32 and } 34\end{array}$ & 0.3113 & \\
\cline { 1 - 2 } $\begin{array}{c}\text { Branch \#54, Junction \#1 } \\
\text { between volumes \#52 and 54 }\end{array}$ & 0.3119 & \\
\cline { 1 - 2 } $\begin{array}{c}\text { Branch \#74, Junction \#1 } \\
\text { between volumes \#72 and 74 }\end{array}$ & 5.067 & \\
\hline
\end{tabular}

With the above minor loss coefficients included, the pressure distribution from the inlet pressure measurement to the lower support grid within the reactor vessel where in good agreement with measurements. Comparison of simulations to the DPRCA measurement indicated that additional pressure loss was required in the model between the lower support grid and the outlet pressure measurement. However, no additional measurements were made between these two locations. After reviewing the impact of including a minor loss coefficient at different locations, it was decided that there was no ideal location. For simplicity, the minor loss coefficient (11.2) was placed at the junctions between the reactor vessel and outlet piping (junctions 991 and 992). The large minor loss coefficient value is justified since the pressure loss from the complex 3-dimensional flow pattern in the lower region of the pressure vessel cannot be modeled accurately by RELAP5 (1-dimensional code).

\subsubsection{Calibration summary}

Figure 12 shows the results for the calibrated RELAP5 model compared to experimental data. Figure 12a includes core pressure drop measurement data for the 1962 BR2 experiments, 1973/74 BR2 experiments and the 1963 BR2 experiment (to be simulated). The RELAP5 simulations produce good agreement with the 1962 data for both nominal flow rates and reduced flow rates. The RELAP5 simulations for the 1963 core configuration produces the correct pressure drop but has a flow rate slightly less than its experimental counterpart. The RELAP5 flow rate is specified based on the core configuration and expected flow in each channel (see Table 4). The difference between this and the measured flow rate is likely due to the uncertainty in the flow measurement of the reactor and the uncertainty in the specified flow given in Table 4. Regardless, the target flow $(10.4 \mathrm{~m} / \mathrm{s})$ is achieved in the fuel element for the simulations.

Figure $12 \mathrm{~b}$ is a similar graph that shows the pressure drop across the reactor vessel. The simulations for the 1962 core configurations are reasonable but do show a trend of increasing pressure drop with increased flow rate at nominal conditions. The minor loss coefficient accounting for the pressure loss in the lower region of the pressure vessel produced results similar to the 1963 BR2 experimental measurements and so it was utilized for those simulations. Preliminary simulations of the representative core indicated that the removing the minor loss coefficient completely was required to achieve the expected results $\left(3.1 \mathrm{~kg} / \mathrm{cm}^{2}\right)$. As a result, a minor loss coefficient was not included at the reactor vessel outlet piping for the representative core model. Further work may be required to resolve this issue. 


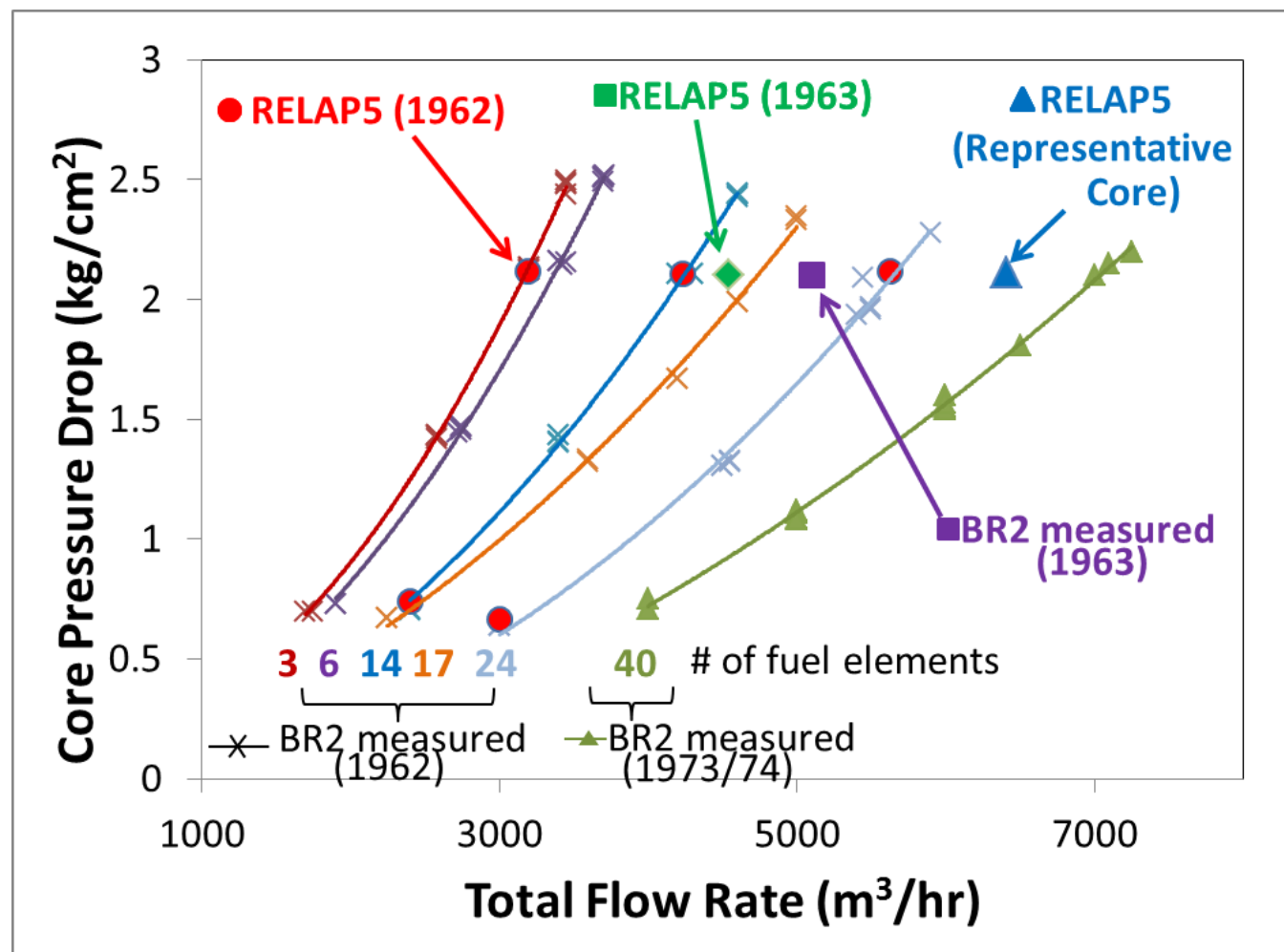

(a)

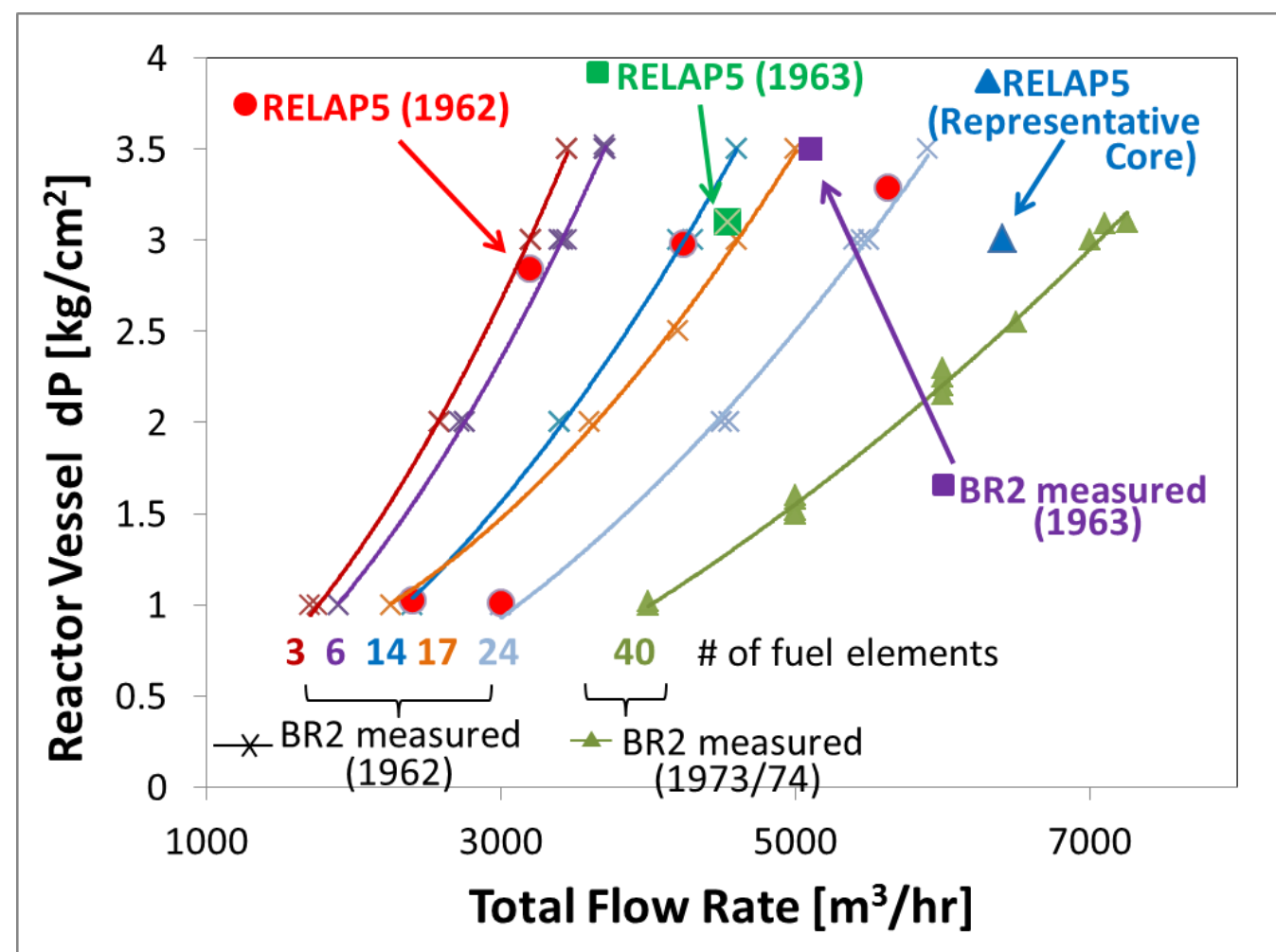

(b)

Figure 12 Comparison of RELAP5 pressure loss simulations to 1962 and 1973/74 BR2 hydraulic tests. Data for the 1963 BR2 core configuration and estimated results for the representative core are also shown. 
These loss coefficients, or correction factors, needed to achieve the correct flow rates and pressure losses are justified since the hydraulic parameters determined for the reference RELAP5 model do not exactly represent the reactor, but are a volume averaged approximations to it. The correction factors account for the differences between the volume averaged approximation and the reality of the reactor components. For example, the large correction factor for the bypass channel accounts for the many small triangular flow paths and their contraction at the core centerline caused by the convergence of the angled channels, details that are averaged out in the approximation of the core region. The large loss coefficient for the plugged channel, and its variability, accounts for the fact that there are a variety of hydraulic diameters for the different sections of this channel. It is inherent in the volume averaging of these channels that the resulting hydraulic diameter will under represent the hydraulic resistance of the system. The calibrated loss coefficients correct these issues. The fact that there is good agreement for the loss coefficients across many core configurations is significant because it establishes credibility for the loss coefficients and flow distribution that will be predicted for the representative core since it can be closely tied to the experimental data acquired in the late 1950's and early 1960's.

\subsection{Primary system}

\subsubsection{Pump coast down}

Two sets of pump coast down data were provided by BR2 for model calibration. The first was measured during the 1963 experimental campaign and the second was measured in 2010. As shown in Figure 13, the 2010 pump coast down data was significantly different from the 1963 . The reason for the difference in coast down is not clear at this time so the impact of two known changes to the primary loop was studied. The first is the replacement of the heat exchangers with a new design. The second is the addition of channel perforations ${ }^{7}$ at the elevation that is equivalent to RELAP5 volumes 40,60 and 80 . While design details are not available for either of the above, preliminary simulations with assumed values indicate they have relatively little impact on the pump coast down and may not be the source of the difference. The 2010 and 1963 coast downs can be achieved in RELAP5 simulations by modifying the torque friction (Table 8):

$$
\text { torque friction }=T F 0+T F 1 \cdot S+T F 2 \cdot S^{2}+T F 3 \cdot S^{3}
$$

where ' $S$ ' is the ratio of current speed to rated speed.

Table 8 Torque friction coefficients.

\begin{tabular}{|l|c|c|c|c|}
\hline Data set & TF0 & TF1 & TF2 & TF3 \\
\hline 1963 & 1700 & 0 & 0 & 0 \\
\hline 2010 & 200 & 200 & 100 & 4500 \\
\hline
\end{tabular}

Inspection of these coefficients shows that the simulation of the 1963 data depends entirely on a constant friction coefficient (TFO) while simulation of the 2010 data is largely controlled by the velocity

\footnotetext{
${ }^{7}$ BR2 staff have stated that the reactor design in 1963 did not contain perforations in the lower channel walls at the elevation equivalent to RELAP5 volumes 40,60 and 80 . The perforations were present during the 2010 pump coast down tests. The perforations will not be present at the time the plant is converted from HEU to LEU fuel.
} 
ratio to the third power. This suggests that changes in the systems flow resistance alone aren't sufficient for causing the two coast down profiles.

The RELAP5 coast down profiles do not match the measured values well at low flows but it is known that flow measurements are typically not very accurate below about $10 \%$ of nominal conditions. Thus, the impact on peak clad temperature due the time at which flow approaches zero has been described in the following section on simulation results.

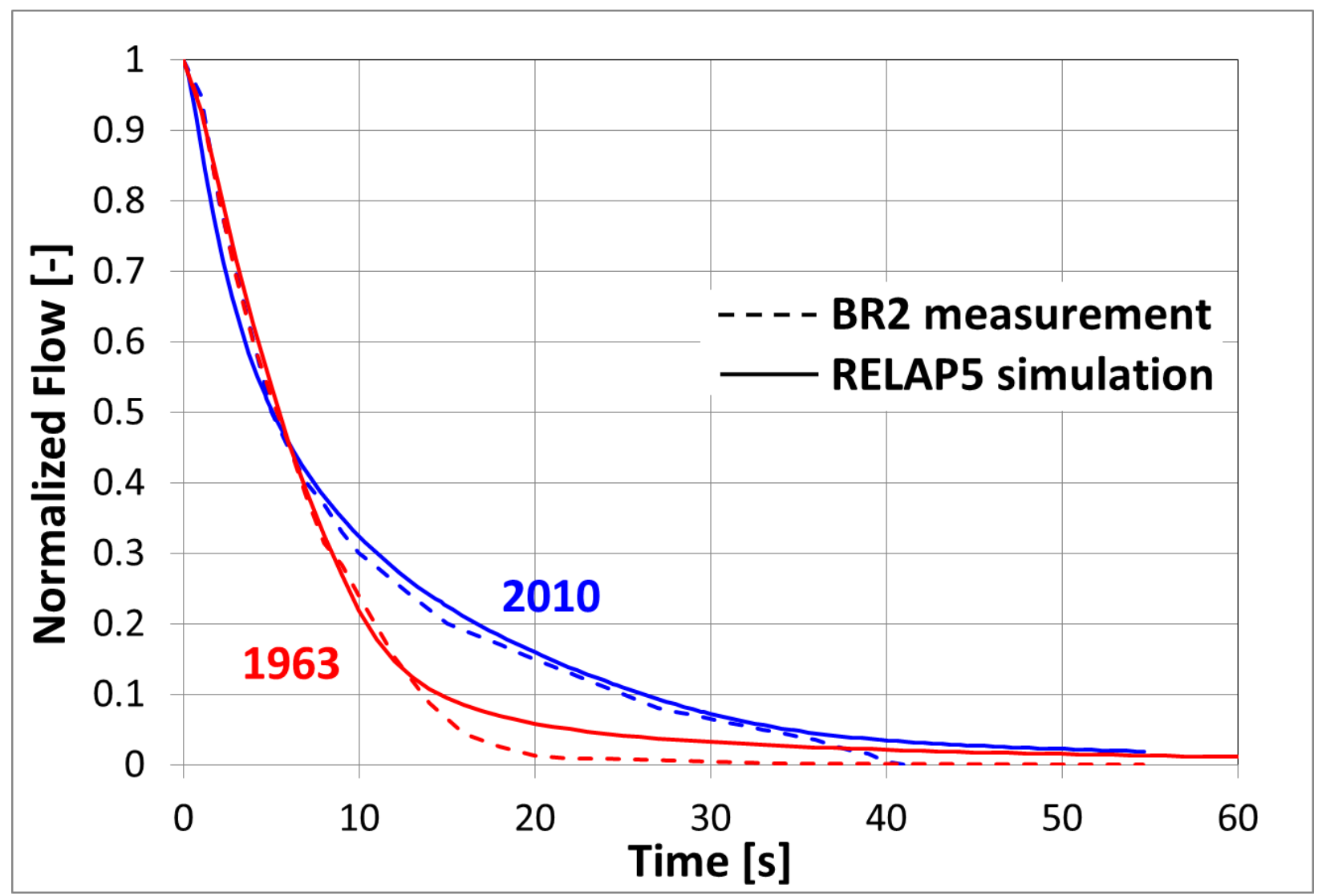

Figure 13 Comparison of the 1963 BR2 pump coast down data to RELAP5 simulations.

\section{Loss-of-Flow and Loss-of-Pressure Simulations}

In 1963, a number of loss-of-flow and loss-of-pressure tests were performed in BR2 to determine the maximum allowable heat flux at which the reactor could be operated safely. The following three tests were selected for the technical basis for RELAP5 simulation of BR2:

- Test $A / 400 / 1$; loss of flow at maximum heat flux of $400 \mathrm{~W} / \mathrm{cm}^{2}$

- Test $\mathrm{C} / 600 / 3$; loss of flow at maximum heat flux of $600 \mathrm{~W} / \mathrm{cm}^{2}$

- Test F/400/1; loss of flow with loss of pressure at maximum heat flux of $400 \mathrm{~W} / \mathrm{cm}^{2}$

The tests sequences of events as well as the simulation results are presented in this section. 
The magnitude and distribution of power for each test are based on MCNP calculations described in [13] and summarized for the RELAP5 model in Appendix C. These power distributions have been modified for this work since the RELAP5 modeling approach was slightly different. Previous simulations modeled fuel plates 4, 5 and 6 in a sector whereas the model described in Section 2 was for a 10 degree azimuthal section these plates. This was done because the local heat flux can increase up to about $30 \%$ (due to azimuthal peaking) depending on the orientation of the fuel element in the 1963 core configuration. For the representative core model, the peak heat flux will be modeled at this hot stripe, but for the 1963 experiments the orientation of the fuel element was not known and has been included in the uncertainty of the simulations. The reference simulations use the average heat flux, meaning that the results here should be consistent with previous RELAP5 simulations performed by ANL $[6,14]$.

Of particular interest in this work is the comparison of the RELAP5 simulation results to the measured fuel cladding temperature from an instrumented fuel assembly (Channel F-346). Thermocouples were located at $300 \mathrm{~mm}$ (TC11), $150 \mathrm{~mm}$ (TC12), $0 \mathrm{~mm}$ (TC13) and -150 mm (TC14) from the fuel centerline at the outside cladding of plate 6 . These locations closely correspond to the locations between RELAP5 heat structure nodes 2-3, 6-7, 10-11 and 14-15, respectively, and RELAP5 volume nodes 3-4, 7-8, 11-12, and 15-16, respectively. Averages of the node values have been reported.

\subsection{Test A}

Test $\mathrm{A}\left(400 \mathrm{~W} / \mathrm{cm}^{2}\right)$ was performed at a reactor power of $24 \mathrm{MW}$. Comparisons of the normal operating conditions are given in Table 9. There are no significant differences between test results and RELAP5, although the cladding temperature under normal operation is predicted to be slightly higher for thermocouple 13. 
Table 9 Comparisons of the normal operating conditions for Test A.

\begin{tabular}{|c|c|c|c|c|}
\hline \multicolumn{2}{|r|}{ Parameter } & \multirow{2}{*}{$\begin{array}{c}\begin{array}{c}\text { RELAP5 } \\
\text { Volume*** }\end{array} \\
16 \\
\end{array}$} & \multirow{2}{*}{$\begin{array}{c}\text { RELAP5 Value } \\
354.9\end{array}$} & \multirow{2}{*}{$\begin{array}{c}\text { Target Value** } \\
361.6\end{array}$} \\
\hline \multirow{9}{*}{$\begin{array}{c}\text { Mass Flow } \\
(\mathrm{kg} / \mathrm{s})\end{array}$} & Bypass & & & \\
\hline & High Heat Flux (Remainder) & 360 & 35.8 & 35.09 \\
\hline & High Heat Flux (channel 5) & 365 & 0.17 & 0.17 \\
\hline & High Heat Flux (Channel 6) & 366 & 0.19 & 0.19 \\
\hline & High Heat Flux (Channel 7) & 367 & 0.26 & 0.25 \\
\hline & High Heat Flux (Total) & 36 & 36.37 & 35.70 \\
\hline & Average Fuel element & 56 & 472 & 463.70 \\
\hline & Plugged Channels & 76 & 376.0 & 376.40 \\
\hline & Total & 8 & 1239.7 & 1237.3 \\
\hline \multirow{10}{*}{$\begin{array}{l}\text { Pressure } \\
\left(\mathrm{kg} / \mathrm{cm}^{2}\right)\end{array}$} & PRCA & $255(1)$ & 12.7 & 12.7 \\
\hline & DPRCA & $255(1)-201(6)$ & 3.1 & 3.5 \\
\hline & Pin - PS & $255(1)-10$ & -0.01 & $0 *$ \\
\hline & Ps - PI & $10-40$ & 2.6 & 3* \\
\hline & Ps - Pi1 & $10-34$ & 0.5 & 0.60 \\
\hline & & $12-14$ & 0.2 & $0.2^{*}$ \\
\hline & Pi1-Pi2 & $34-38$ & 2.06 & 2.04 \\
\hline & $\mathrm{Pi2}-\mathrm{PI}$ & $38-40$ & 0.02 & $0 *$ \\
\hline & PI-Pout & $40-201(6)$ & 0.5 & $0.6^{*}$ \\
\hline & DPRCA-(Ps-PI) & & 0.50 & $0.5-0.6^{*}$ \\
\hline \multirow{7}{*}{$\begin{array}{c}\text { Temperature } \\
\left({ }^{\circ} \mathrm{C}\right)\end{array}$} & Tin & 8 & 34.8 & 34.80 \\
\hline & Tout & 24 & 39.3 & 39.90 \\
\hline & $\mathrm{dT}$ & Tout-Tin & 4.5 & 5.10 \\
\hline & TC11 & $366(2-3)$ & 41.8 & 40.6 \\
\hline & TC12 & $366(6-7)$ & 56.6 & 53.0 \\
\hline & TC13 & $366(10-11)$ & 99.9 & 89.5 \\
\hline & TC14 & $366(14-15)$ & 116.1 & 113.1 \\
\hline
\end{tabular}

*Indicates value is an estimate and not a measurement.

** Mass flow values based on Table 4 flow distribution. Fuel element flows scaled by flow area.

***RELAP5 number format: volume number followed by segment number in parenthesis.

The transient was characterized by a loss of power to the main pumps at $5.35 \mathrm{~s}$ followed by a reactor scram at $7.7 \mathrm{~s}$. The bypass valve started to open at $22.0 \mathrm{~s}$ and was completely open at $35.6 \mathrm{~s}$. All other parameters were unchanged.

Figure 14 shows a comparison of the RELAP5 simulation results and the measured cladding temperature for thermocouples 11 through 14. Early in the transient the results are representative of normal operating conditions. The fact that there is general agreement between measurement and simulation suggests that the orientation of the fuel bundle is such that the thermocouples are located in a region where the heat flux is representative of the average power of the $6^{\text {th }}$ plate. The temporary rise in temperature starting at $5.35 \mathrm{~s}$ is due to the decrease in the flow-to-power ratio resulting from the fact that the pump trip occurred before the reactor scram. This peak is only present in Test A since for Tests $\mathrm{C}$ and $\mathrm{F}$, the reactor was scrammed before the pumps were tripped. The reactor scram occurs at $7.7 \mathrm{~s}$; 
because the flow rate decreases relatively slow (Figure 15), the heat transfer coefficient remains high and the cladding temperature rapidly approaches the bulk coolant inlet temperature. The flow rate decreases in a manner that allows the channel coolant to reach inlet conditions. As evident in Figure 15, a slowing down of the bulk coolant to zero flow rate results in a momentary period in which the coolant resides near stationary in the fuel element receiving heat. The increase in bulk coolant temperature eventually results in a buoyancy driven flow reversal that draws water from below the core, which in combination with the increase in heat transfer coefficient, results in the peak, decline and leveling of the cladding temperature. Figure 14 shows that the RELAP5 model captures these magnitudes and timings with good agreement. It is also worth mentioning that Figure 15 shows the maximum temperature for the first peak occurs on the outer face of plate 6 and for the second peak on the outer face of plate 5 . The magnitude is highest for both at an elevation of $36.2 \mathrm{~cm}$ from the bottom of the plate. The simulation results presented here are consistent with previous results simulations performed by ANL and described in [6]. However, there are several additional points to make regarding agreements and differences between the model and measurements.

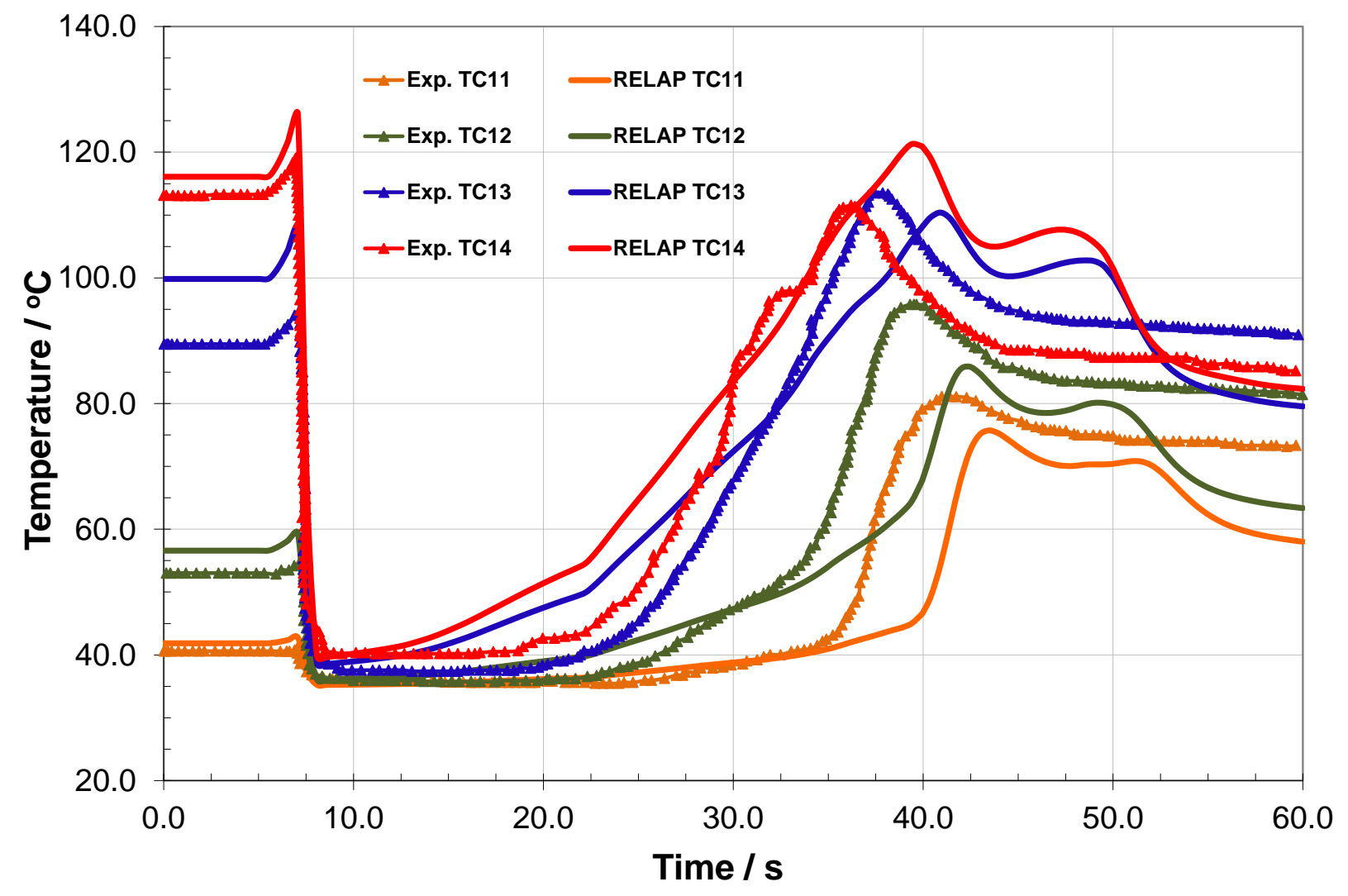

Figure 14 Comparison of the 1963 Test A cladding temperature measurement and RELAP5 simulations. 


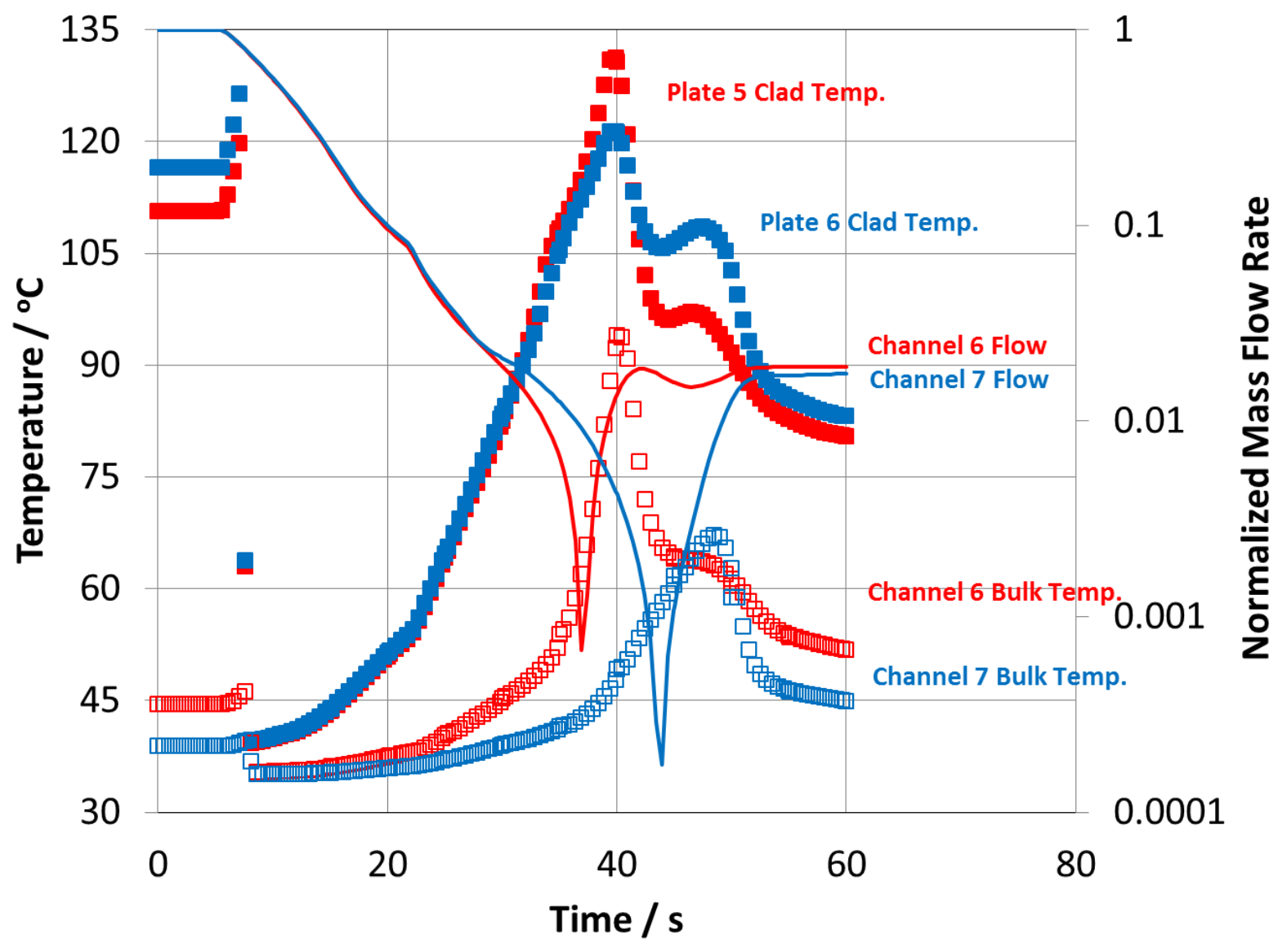

Figure 15 Time evolution of parameters impacting peak temperature (RELAP5 simulation results at an elevation of $36.2 \mathrm{~cm}$ from the bottom of the fuel plate). Plate temperatures represent the outer face of the plate.

First, the RELAP5 model shows an additional peak in temperature following the second peak that is not present in the experimental results. This is consistent with previous RELAP5 simulation results [6] where the fuel element model included the entire channel sector as opposed to the 10 degree hot stripe. Closer inspection of Figure 15 shows that the double peak is due to the timing and duration of the flow reversal in the two adjacent channels, where channel 6 reverses at $36.9 \mathrm{~s}$ and channel 7 reverses at $43.9 \mathrm{~s}$ (for reference, coolant in the remainder of the high heat flux channel and average channels reverses direction at $40.0 \mathrm{~s}$ and $40.9 \mathrm{~s}$, respectively). This behavior might be expected since heat input is the driver of flow reversal and its duration; channel 7 acquires heat mainly from one fuel plate (a small amount of heat might be contributed from the beryllium depending on the flow conditions in channel 7 and the bypass) while channel 6 acquires heat from two fuel plates. The time it takes for flow reversal to occur may also be impacted by the fact that the local flow conditions are different in channel 7. Coolant near the fuel plate will tend to rise and coolant near the cooler beryllium wall will tend sink, details that are not captured in a 1-D code. Figure 16 shows the cladding temperature and includes the uncertainty for a $\pm 20 \%$ in the heat transfer coefficient. For comparison the RELAP5 predicted heat transfer coefficient is shown. It is clear that as the flow reversal occurs, the code switches to and from a natural convection based heat transfer correlation and does so rather discontinuously. None of these factors 
described above can be readily improved upon in the RELAP5 model and should be considered as part of the uncertainty of these results.

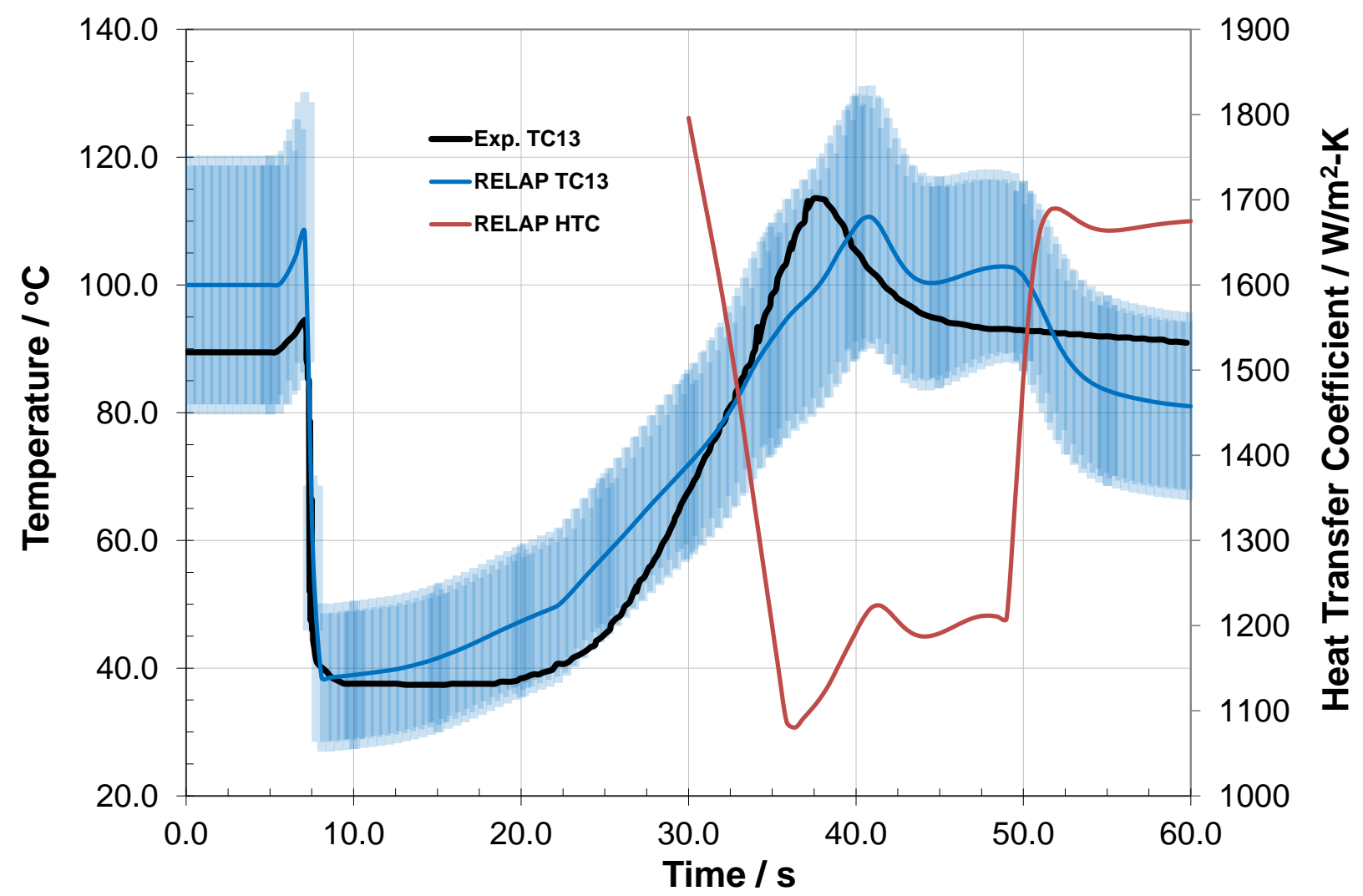

Figure 16 TC13 cladding temperature with $\pm 20 \%$ uncertainty in heat transfer coefficient. RELAP5 predicted heat transfer coefficient at the location of TC13 also shown.

The second observation is the timing of the peak cladding temperature. It was mentioned earlier (Section 3.2.1) that the pump coast down simulations differed from measurements at low flow rate, resulting in a delay in the time at which the flow rate reaches zero. A separate RELAP5 simulation was run with the primary system forced to the 1963 measured coast down flow rate (see red dashes in Figure 13). Figure 17 compares the cladding temperatures at the location of TC13 for both coast down simulations. The peak cladding temperature for the "measured coast down" occurs $8.6 \mathrm{~s}$ earlier than the "simulated coast down" but only results in a $4.6^{\circ} \mathrm{C}$ increase in temperature. This increase in peak temperature is related to the difference in decay power at the time of flow reversal. If the slope of the temperature ramp prior to the temperature peak is an indicator of the correct flow rate in the channel, the actual coast down flow rate should be somewhere between the two simulated cases. 


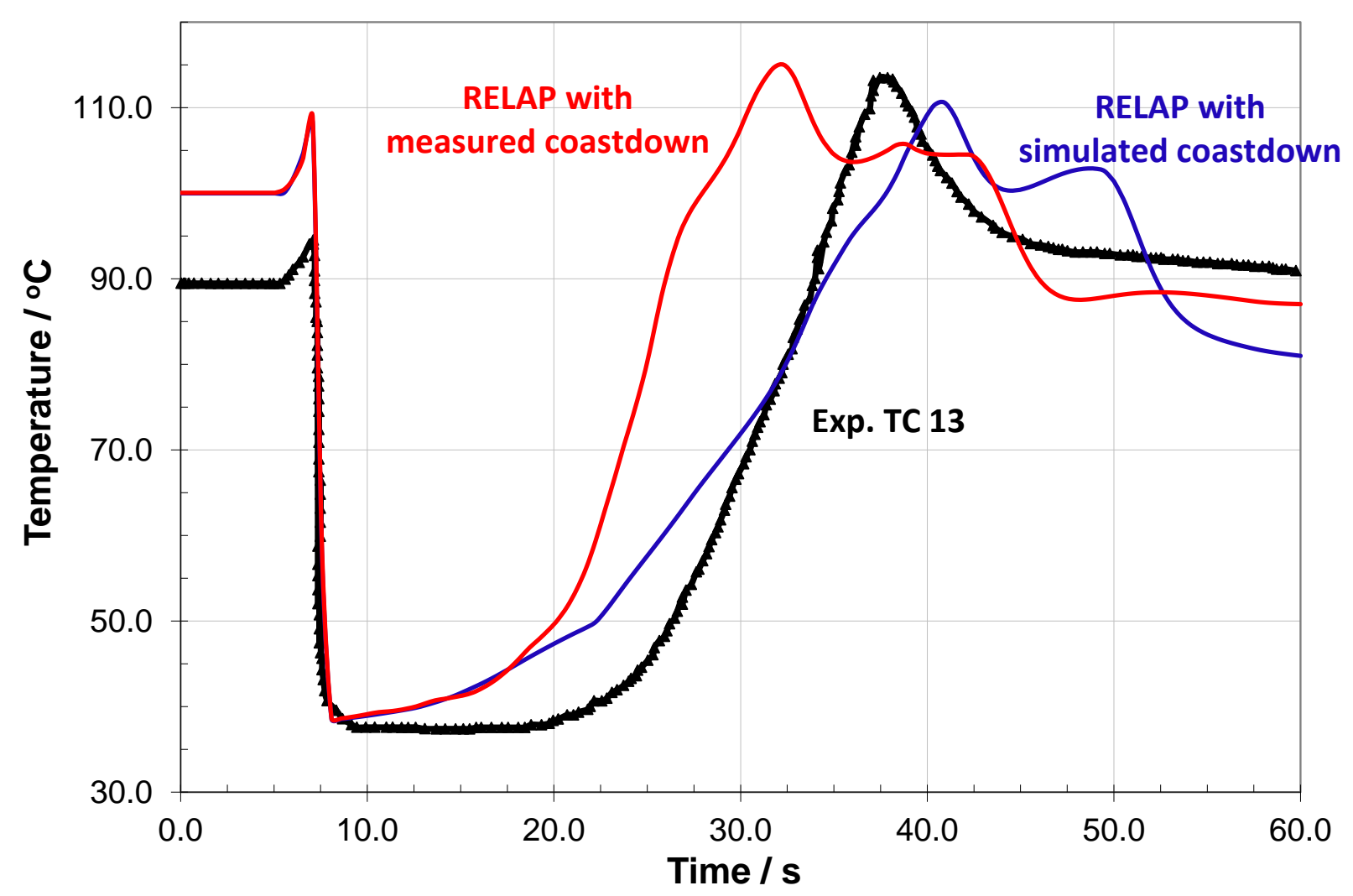

Figure 17 Predicted TC13 cladding temperature for the simulated and measured coast down.

It can't be ruled out that the mismatch in flow reversal and differences in pump coast down aren't biases that offset each other and result in a peak temperature that roughly coincides with the experimental data in both time and magnitude. However, given the discussion for the mechanisms involved, an estimate of the peak cladding temperature that bounds the expected results can be derived from first principles (see Appendix D). Utilizing the Churchill-Chu natural convection heat transfer coefficient [15], a lower bound on the peak cladding temperature can easily be determined by assuming a bulk coolant temperature at cold conditions and parametrically evaluating the heat flux as a function of flow reversal time. An upper limit can be determined by estimating the maximum bulk coolant temperature that might be achieved during the flow reversal process. Balancing the resistive flow losses in the channel with buoyancy forces, a residence time (amount of heat input) for the slug of coolant that impact the peak cladding temperature can be estimated. Figure 18 illustrates the range of predicted peak cladding temperature as function of time that flow reversal occurs. The shape of the trend indicates that the peak cladding temperature is not significantly sensitive to the flow reversal time (with respect the time that it occurs). In other words, while it's possible there are biases that impact the timing of the peak cladding temperature, they won't significantly impact the magnitude of the temperature in excess of the normal uncertainties. 


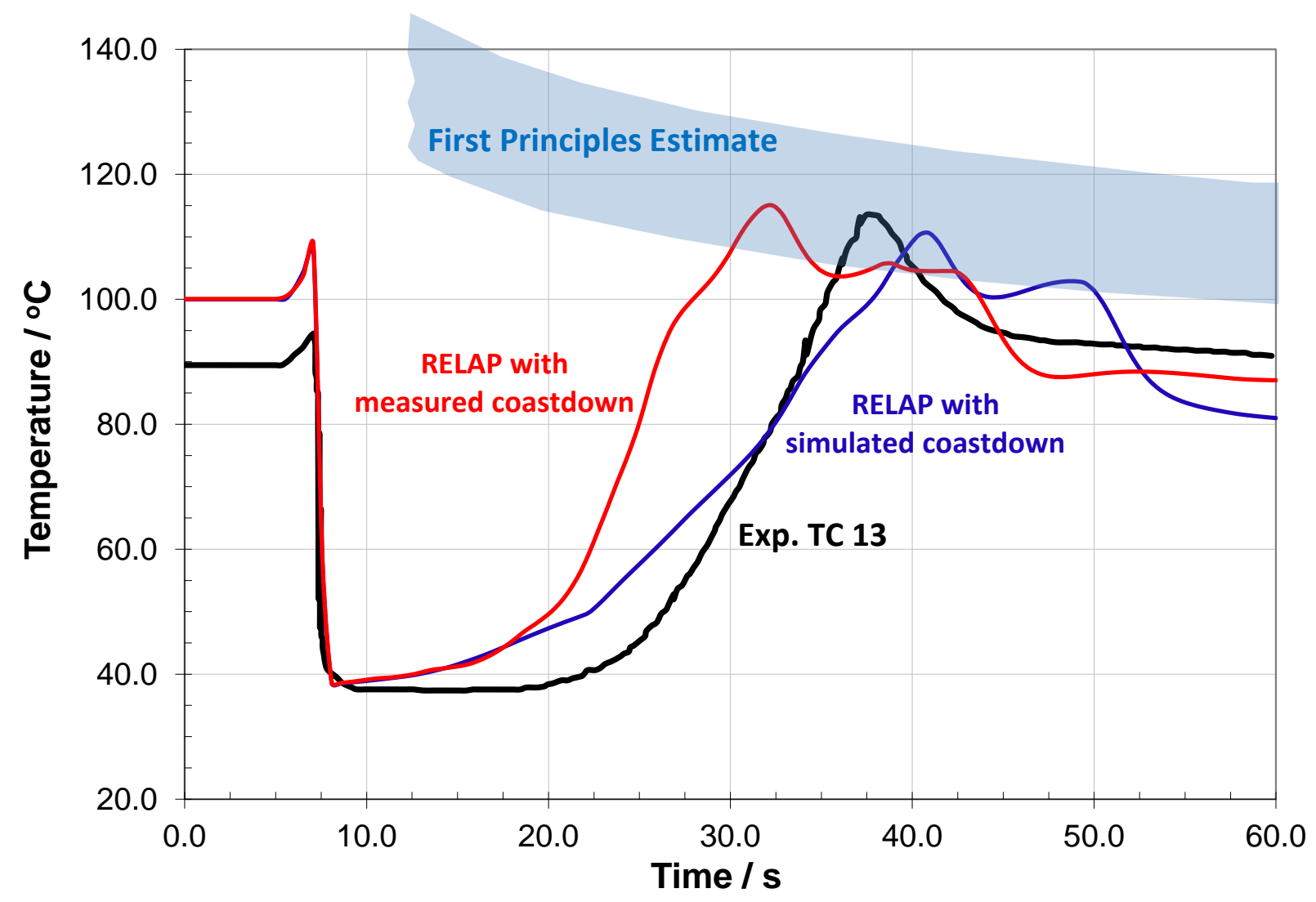

Figure 18 Predicted peak cladding temperature at TC13 determined from a first principles estimation.

\subsection{Test C}

Test $\mathrm{C}\left(600 \mathrm{~W} / \mathrm{cm}^{2}\right)$ was performed at a reactor power of $36 \mathrm{MW}$. The sequence of events was similar to Test A. Comparisons of the normal operating conditions are given in Table 10. There are no significant differences between test results and RELAP5, although the cladding temperature under normal operation is predicted to be slightly higher for thermocouple 13.

The transient was characterized by a loss of power to the main pumps at $6.65 \mathrm{~s}$ and a reactor scram at $6.55 \mathrm{~s}$. The bypass valve started to open at $6.52 \mathrm{~s}$ and was completely open at $21.7 \mathrm{~s}$. All other parameters were unchanged.

Figure 19 shows a comparison of the RELAP5 simulation results and the measured cladding temperature for thermocouples 11 through 14. There are no significant differences between the trends shown here and those seen in Test A except for the magnitude (larger) and timing (earlier) of the peak cladding temperature. Also, the pump trip occurs $0.1 \mathrm{~s}$ after the reactor scram so there is no initial peak in temperature. Regardless, there is generally good agreement between the measured and simulated results.

The simulation results presented here are also consistent with previous results simulations performed by ANL and described in [14]. 
Table 10 Comparisons of the normal operating conditions for Test $C$.

\begin{tabular}{|c|c|c|c|c|}
\hline \multicolumn{2}{|c|}{ Parameter } & \multirow{2}{*}{$\begin{array}{c}\begin{array}{c}\text { RELAP5 } \\
\text { Volume }\end{array} * * \\
16\end{array}$} & \multirow{2}{*}{$\begin{array}{l}\text { RELAP5 } \\
\text { Value } \\
354.8\end{array}$} & \multirow{2}{*}{$\begin{array}{c}\text { Target Value** }^{* *} \\
361.6 \\
\end{array}$} \\
\hline \multirow{9}{*}{$\begin{array}{l}\text { Mass Flow } \\
(\mathrm{kg} / \mathrm{s})\end{array}$} & Bypass & & & \\
\hline & High Heat Flux (Remainder) & 360 & 35.8 & 35.09 \\
\hline & High Heat Flux (channel 5) & 365 & 0.17 & 0.17 \\
\hline & High Heat Flux (Channel 6) & 366 & 0.20 & 0.19 \\
\hline & High Heat Flux (Channel 7) & 367 & 0.26 & 0.25 \\
\hline & High Heat Flux (Total) & 36 & 36.42 & 35.70 \\
\hline & Average Fuel element & 56 & 473 & 463.70 \\
\hline & Plugged Channels & 76 & 376.0 & 376.40 \\
\hline & Total & 8 & 1240.0 & 1237.3 \\
\hline \multirow{10}{*}{$\begin{array}{l}\text { Pressure } \\
\left(\mathrm{kg} / \mathrm{cm}^{2}\right)\end{array}$} & PRCA & $255(1)$ & 12.7 & 12.7 \\
\hline & DPRCA & $255(1)-201(6)$ & 3.1 & 3.5 \\
\hline & Pin - PS & $255(1)-10$ & -0.01 & $0 *$ \\
\hline & $\mathrm{Ps}-\mathrm{PI}$ & $10-40$ & 2.6 & 3* \\
\hline & Ps - Pi1 & $10-34$ & 0.5 & 0.60 \\
\hline & & $12-14$ & 0.2 & $0.2^{*}$ \\
\hline & Pi1-Pi2 & $34-38$ & 2.06 & 2.15 \\
\hline & $\mathrm{Pi} 2-\mathrm{PI}$ & $38-40$ & 0.02 & $0 *$ \\
\hline & PI-Pout & $40-201(6)$ & 0.5 & $0.6^{*}$ \\
\hline & DPRCA-(Ps-PI) & & 0.5 & $0.5-0.6^{*}$ \\
\hline \multirow{7}{*}{$\begin{array}{c}\text { Temperature } \\
\left({ }^{\circ} \mathrm{C}\right)\end{array}$} & Tin & 8 & 34.9 & 35.2 \\
\hline & Tout & 24 & 41.4 & 41.8 \\
\hline & dT & Tout-Tin & 6.5 & 6.6 \\
\hline & TC11 & $366(2-3)$ & 46.1 & 48.4 \\
\hline & TC12 & $366(6-7)$ & 70.1 & 75.2 \\
\hline & TC13 & $366(10-11)$ & 129.8 & 119.0 \\
\hline & TC14 & $366(14-15)$ & 146.7 & 151.8 \\
\hline
\end{tabular}

*Indicates value is an estimate and not a measurement.

**Mass flow values based on Table 4 flow distribution. Fuel element flows scaled by flow area.

***RELAP5 number format: volume number followed by segment number in parenthesis. 


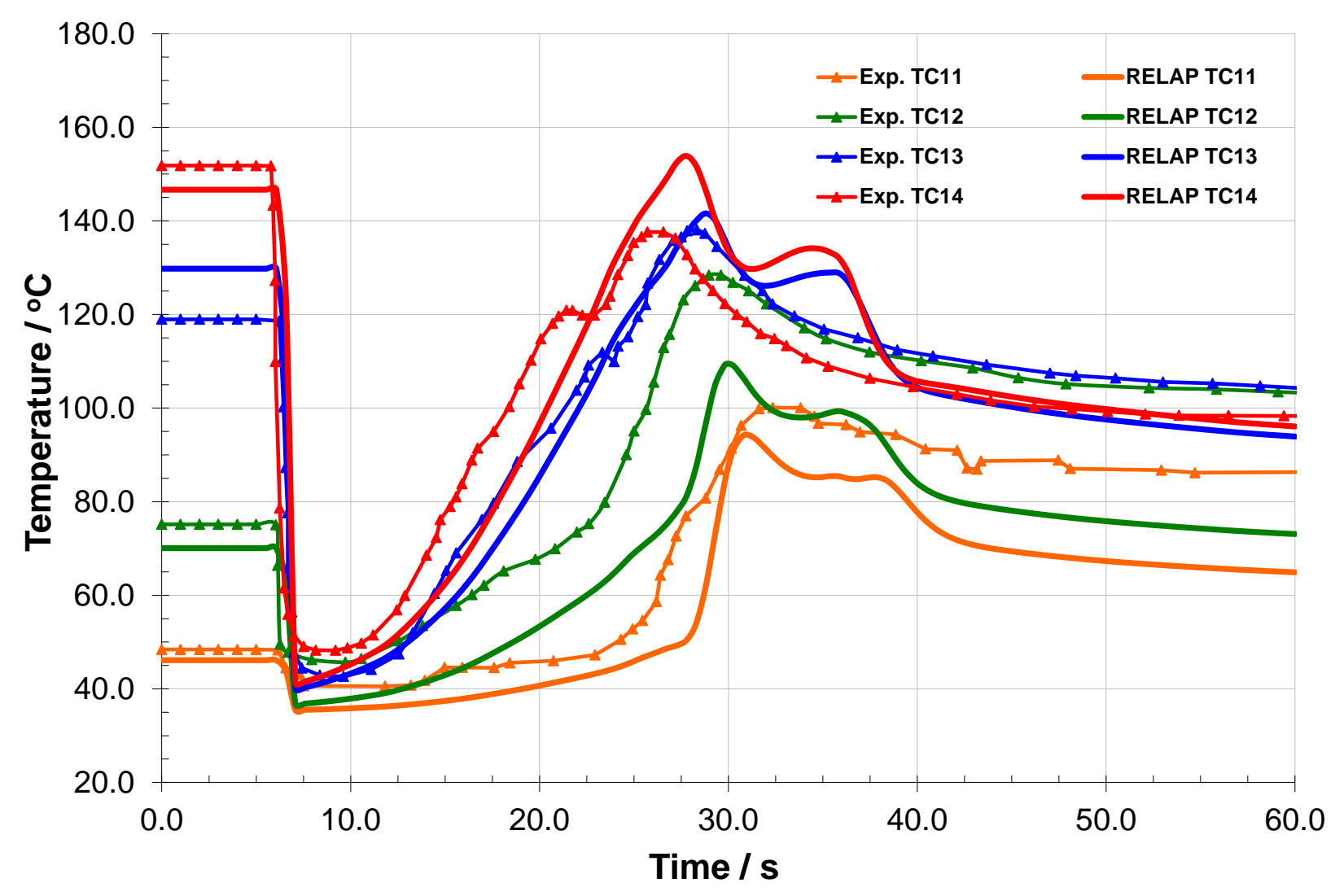

Figure 19 Comparison of the 1963 Test C cladding temperature measurement and RELAP5 simulations.

\subsection{Test $\mathbf{F}$}

Test $\mathrm{F}\left(400 \mathrm{~W} / \mathrm{cm}^{2}\right)$ was performed at a reactor power of $24 \mathrm{MW}$. The sequence of events was similar to test $A$ except that it included a coincidental loss of pressure. Comparisons of the normal operating conditions are given in Table 11. There are no significant differences between test results and RELAP5 simulations.

The transient was characterized by a loss of power to the main pumps at $10.2 \mathrm{~s}$ followed by a reactor scram at $11.1 \mathrm{~s}$ (similar to Test $\mathrm{C}$, the first temperature peak will not exist since the scram occurs before the pump trip). The loss of pressure was initiated at $11.1 \mathrm{~s}$ by opening the relief valve. It completed opening at $17.45 \mathrm{~s}$. The upstream pump isolation valve began closing at $18.6 \mathrm{~s}$ and was completed at $47.7 \mathrm{~s}$. The downstream pump isolation valve began closing at $18.45 \mathrm{~s}$ and was complete at $45.15 \mathrm{~s}$. The bypass valve started to open at $26.45 \mathrm{~s}$ and was completely open at $42.35 \mathrm{~s}$. All other parameters were unchanged.

Figure 20 shows a comparison of the RELAP5 simulation results and the measured cladding temperature for thermocouples 11 through 14. The results are quite similar Test $A$ despite the fuel centerline pressure leveling off to $170 \mathrm{kPa}$ after $25 \mathrm{~s}$ (Test A pressure was $1.36 \mathrm{MPa}$ ). At this pressure the saturation temperature is $\sim 115^{\circ} \mathrm{C}$, a value similar to the peak cladding temperature. Investigation of the 
heat transfer coefficient at the outside of plate 6 indicates that nucleate boiling occurs for a very limited time $(42.4 \mathrm{~s}-44.4 \mathrm{~s}$ ) between elevations $0 \mathrm{~cm}$ and $-21 \mathrm{~cm}$ (Figure 21). Nucleate boiling is also found at the other fuel plates of the high heat flux channels for a similar elevation and duration.

At the location of TC11, the cladding temperature remains near the peak value much longer than in the other thermocouples, and for some time after the peak, it is nearly equal to that in TC14, although the power at TC14 is about eight times higher. This, as well as the time trace of TC11, indicate that most likely this thermocouple failed near the time of the peak.

This test was performed at the same power as Test A. At steady state the temperatures of thermocouples TC11, TC13, and TC14 for tests $\mathrm{F}$ and A are much closer to each other than those measured by TC12. Also, although the power at the location of TC12 is much lower than that at TC13 and TC14, after the peak, where a quasi-steady state is reached, the temperature given by TC12 is higher than that of TC13 and TC14. Most likely TC12 had also failed at the time of test F.

The simulation results presented here are also consistent with previous results simulations performed previously by ANL [14]. 
Table 11 Comparisons of the normal operating conditions for Test $F$.

\begin{tabular}{|c|c|c|c|c|}
\hline \multicolumn{2}{|c|}{ Parameter } & \multirow{2}{*}{$\begin{array}{l}\text { RELAP5 } \\
\text { Volume*** } \\
16\end{array}$} & \multirow{2}{*}{$\begin{array}{l}\text { RELAP5 } \\
\text { Value } \\
354.9\end{array}$} & \multirow{2}{*}{$\begin{array}{c}\text { Target Value** }^{* *} \\
361.6 \\
\end{array}$} \\
\hline \multirow{9}{*}{$\begin{array}{l}\text { Mass Flow } \\
(\mathrm{kg} / \mathrm{s})\end{array}$} & Bypass & & & \\
\hline & High Heat Flux (Remainder) & 360 & 35.8 & 35.09 \\
\hline & High Heat Flux (channel 5) & 365 & 0.17 & 0.17 \\
\hline & High Heat Flux (Channel 6) & 366 & 0.19 & 0.19 \\
\hline & High Heat Flux (Channel 7) & 367 & 0.26 & 0.25 \\
\hline & High Heat Flux (Total) & 36 & 36.37 & 35.70 \\
\hline & Average Fuel element & 56 & 472 & 463.70 \\
\hline & Plugged Channels & 76 & 376.0 & 376.40 \\
\hline & Total & 8 & 1239.7 & 1237.3 \\
\hline \multirow{10}{*}{$\begin{array}{l}\text { Pressure } \\
\left(\mathrm{kg} / \mathrm{cm}^{2}\right)\end{array}$} & PRCA & $255(1)$ & 12.71 & 12.7 \\
\hline & DPRCA & $255(1)-201(6)$ & 3.1 & 3.5 \\
\hline & Pin - PS & $255(1)-10$ & -0.01 & 0* \\
\hline & $\mathrm{Ps}-\mathrm{PI}$ & $10-40$ & 2.6 & 3* \\
\hline & Ps - Pi1 & $10-34$ & 0.5 & 0.60 \\
\hline & & $12-14$ & 0.2 & $0.2^{*}$ \\
\hline & Pi1-Pi2 & $34-38$ & 2.06 & 2.04 \\
\hline & $\mathrm{Pi} 2-\mathrm{PI}$ & $38-40$ & 0.02 & $0 *$ \\
\hline & PI-Pout & $40-201(6)$ & 0.5 & $0.6^{*}$ \\
\hline & DPRCA-(Ps-PI) & & 0.5 & $0.5-0.6^{*}$ \\
\hline \multirow{7}{*}{$\begin{array}{c}\text { Temperature } \\
\left({ }^{\circ} \mathrm{C}\right)\end{array}$} & Tin & 8 & 34.8 & 34.8 \\
\hline & Tout & 24 & 39.1 & 39.8 \\
\hline & $\mathrm{dT}$ & Tout-Tin & 4.3 & 5.0 \\
\hline & TC11 & $366(2-3)$ & 44.4 & 47.9 \\
\hline & TC12 & $366(6-7)$ & 70.6 & 77.5 \\
\hline & TC13 & $366(10-11)$ & 101.4 & 96.5 \\
\hline & TC14 & $366(14-15)$ & 105.5 & 116.8 \\
\hline
\end{tabular}

*Indicates value is an estimate and not a measurement.

** Mass flow values based on Table 4 flow distribution. Fuel element flows scaled by flow area.

***RELAP5 number format: volume number followed by segment number in parenthesis. 


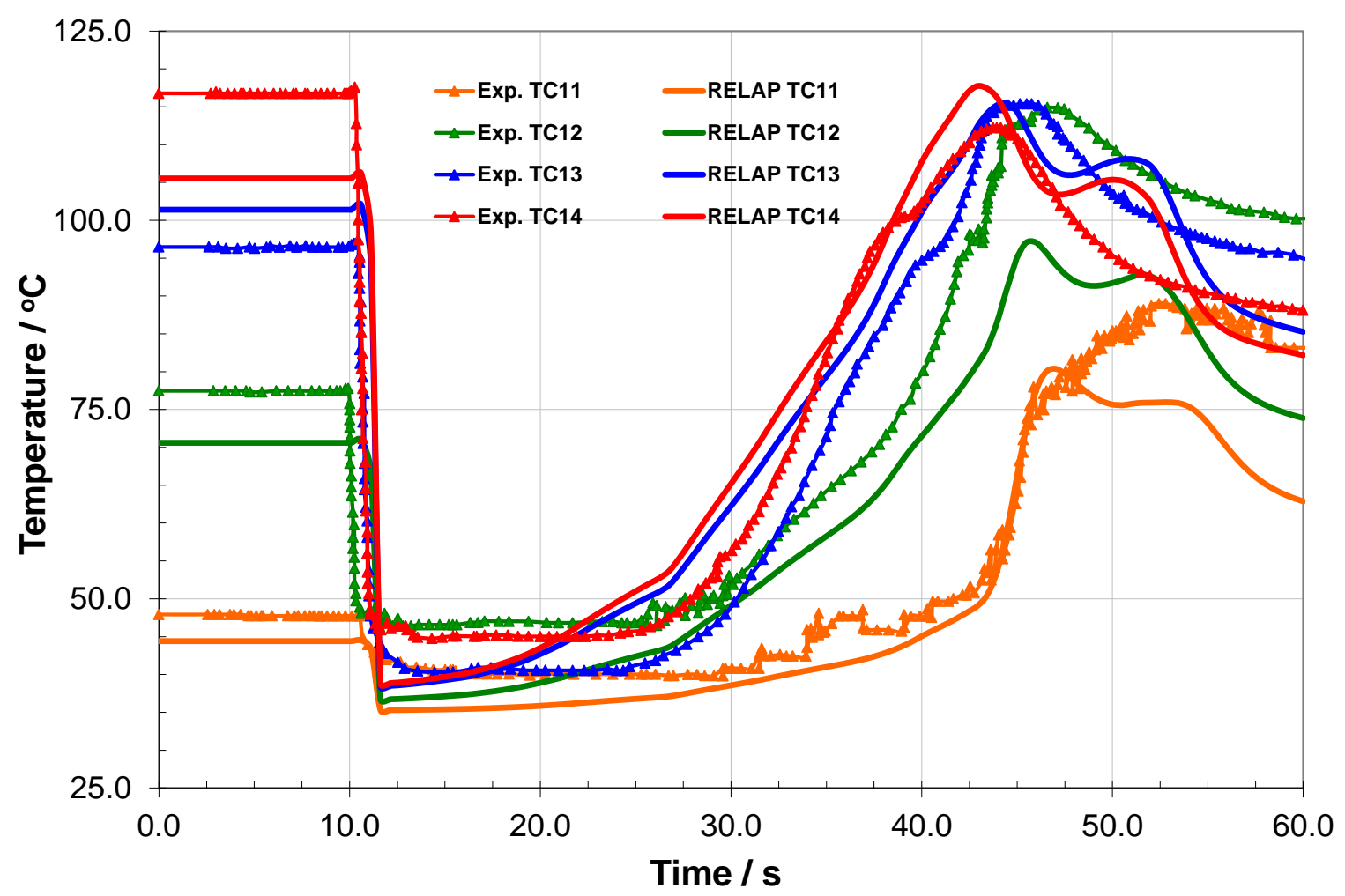

Figure 20 Comparison of the 1963 Test F cladding temperature measurements and RELAP5 simulations.

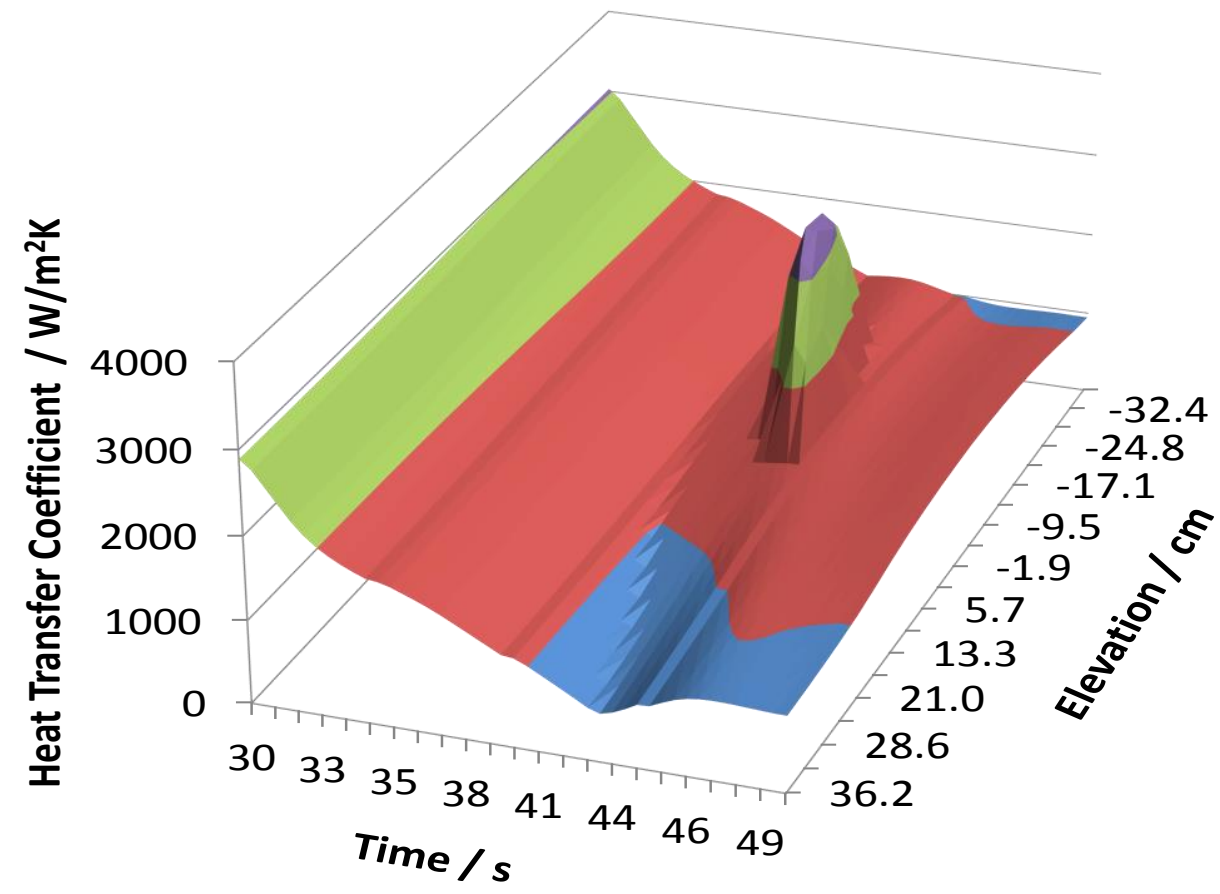

Figure 21 Heat transfer coefficient as a function of time and elevation to illustrate region of nucleate boiling (outside of plate 6). 


\section{Summary}

The purpose of this document was to describe the RELAP5 model of the BR2 reactor vessel and to demonstrate that the RELAP5 modeling strategy is suitable for conversion analyses work through comparisons of experimental data and previous RELAP5 simulations. The end result is that the modeling strategy is verified and confidence has been established for simulating the BR2 representative core with both HEU and LEU fuels.

Section 2 described the BR2 reactor vessel and internal component geometries and its discretization into the various RELAP5 components. A key difference from previous models was the discretization of the coolant and structure in the channel containing the high heat flux fuel element to better represent the peaking of the heat flux and to conservatively capture the local bulk coolant temperature. A secondary difference was the simplification of the model by treating all of the channels as vertical rather than accounting for the angle of each. Section 2 also briefly described updates to the primary coolant system outside the reactor vessel.

A significant effort in this work was the calibration of the RELAP5 model as described in Section 3. Rather than directly calibrating the RELAP5 model to the 1963 experimental data, comparisons were made to a majority of the detailed BR2 data from 1962 and the hydraulic mock-up facility. This resulted in a more generically applicable RELAP5 model since it was not calibrated specifically to the experiment being modeled. The fact that there was good agreement for the loss coefficients across many core configurations was significant because it establishes credibility for the loss coefficients and calculated flow distributions that will be predicted for the representative core in the conversion analyses.

The good agreement between RELAP5 simulations and the experimental data for the 1963 loss-of-flow and loss-of-pressure simulations presented in Section 4 provides verification of the modeling approach. Agreement with previously published RELAP5 simulations by ANL [6] [14] was also expected as the model isn't necessarily better at predicting the 1963 experimental data; rather, the benefit of the current model is that it incorporates the best modeling judgment of ANL and the BR2 engineers that has evolved from past work. Additionally, having reviewed and updated the RELAP5 model with respect to plant design means that certain aspects of the RELAP5 model should not need to be revisited throughout the conversion process; they are fixed regardless of core configuration. For those components that do change due to core configuration, the model setup and calibration is now sufficiently established so that work can proceed to the conversion analyses associated with the representative core containing HEU and LEU fuel. 


\section{References}

[1] Information Systems Laboratories Inc., 2003. RELAP5/Mod3.3 patch 03 Code Manual.

[2] G. Van den Branden, "Conversion Studies: BR2 Reference Data Representative Core", BR2/RCE/GVdB/2013/186/Conversion_studies_Representative_core-ed 1, 21-10-2013.

[3] E. Sikik and G Van Den Branden, "Conversion Studies BR2 Reference Data Part 2 Primary Loop", BR2/RCE/GVdB/2013/188/RELAP_primary_in_pool-ed 1 Draft, November 2013.

[4] G. Van den Branden, "Conversion Studies: BR2 Reference Data Part 1: Vessel, Reactor core, Load elements", BR2/RCE/GVdB/2011/90/Reference_data_part-ed 1, 29-09-2011.

[5] B. Dionne, Y.S. Kim, and G.L. Hofman, "Thermal properties for the thermal-hydraulics analyses of the BR2 maximum nominal heat flux", ANL/RERTR/TM-11-20 Rev 0, May 23, 2011.

[6] C.P. Tzanos and B. Dionne, "Analysis of the BR2 Loss-of-Flow Test A," Nucl. Technol., 176. 93 (2011).

[7] B. Dionne and J.G. Stevens, "Applicability of a hot channel factor-based hot stripe approach to model the azimuthal power peaking in a BR2 fuel assembly", $33^{\text {rd }}$ International Meeting on Reduced Enrichment for Research and Test Reactors, October 23-27, 2011

[8] Belgian Engineering Test Reactor BR2. Safety and Design, Final report", 1996. A revision of the report "Belgian Engineering Test Reactor BR2. Safety and Design, preliminary report" May $1^{\text {st }}$, 1961.

[9] A. Beeckmans, "Distribution du debit de refrigerant dans la cuve du réacteur BR2," C.E.N.EURATOM technical note 72.0616 , August $10^{\text {th }}, 1976$.

[10] Operation Group of BR.2 Reactor and Related Installations, C.E.N.-EURATOM technical note NT.71/2435/07/FaM., October $15^{\text {th }}, 1962$.

[11] C. F. Colebrook. "Turbulent Flow in Pipes with Particular Reference to the Transition Region Between Smooth and Rough Pipe Laws." Journal of Institution Civil Engineers. 11. 1939. pp. 133156.

[12] Churchill, S.W. 1977, 'Friction Factor Spans All Fluid Flow Regimes,' Chem. Eng. (Rugby, U.K.) 84(24), pp.91-91).

[13] B. Dionne and C.P. Tzanos, "Estimation of Steady-State and Transient Power Distributions for the RELAP Analyses of the 1963 Loss-of-Flow and Loss-of-Pressure Tests at BR2" ANL/RERTR/TM-1119, (2011).

[14] C.P. Tzanos and B. Dionne, "Analysis of the BR2 Loss-of-Flow Tests C and F," Nucl. Technol., 179. 382 (2012). 
[15] James R. Welty; Charles E. Wicks; Robert E. Wilson; Gregory L. Rorrer (2007). Fundamentals of Momentum, Heat and Mass transfer (5th edition). John Wiley and Sons. ISBN 978-0470128688.

[16] I.E. Idel'chik, Handbook of hydraulic resistance, 1966. 


\section{Appendices}

\section{A Heat Structures}

This section describes the heat structures that make up the BR2 reactor vessel and its internal components (Figure 3). The data has been acquired from legacy documents/notes and RELAP5 input files provided by the BR2 team. The following sections summarize this information.

\section{A.1 Reactor vessel}

The reactor vessel heat structures were labeled 100-106 in the RELAP5 model (Table A-1). Because the structure elevations don't necessarily align with the elevations of the interior or exterior coolant volumes, the heat structures have been discretized axially to accommodate the mismatch.

\section{Heat structure 100}

Heat structure 100 represents the reactor vessel head; it does not include the channels that feed through it as these are accounted for in the channel heat structures. The structure was modeled as a fraction of a sphere in RELAP5, where the sphere fraction is defined as the ratio of the modeled surface area divided by the surface area of a sphere. The cover is not actually a sphere so an equivalent spherical radius was obtained from $R_{\text {sphere }}=A_{c} / 2 \pi h$ where $A_{c}$ is the surface area (this number was defined as $6.9 \mathrm{~m}^{2}$ ) and $h$ is the interior height of the vessel cover (this was defined as $0.835 \mathrm{~m}$ ). Prior to solving for the radius, the surface area of the channels penetrating the cover was subtracted from it resulting in surface area of $6.15 \mathrm{~m}^{2}$. The equivalent sphere radius was calculated to be $1.173 \mathrm{~m}$ and used to obtain the sphere fraction of 0.355 . The vessel cover thickness was specified as $0.038 \mathrm{~m}$. This structure was represented by one node thermally connected to the reactor pool at its exterior and coolant volume 10 at its interior.

\section{$\underline{\text { Heat structure } 101}$}

Heat structure 101 represents the cylindrical vessel section below the upper vessel cover. The height, inner radius and wall thickness were reported as $0.4629 \mathrm{~m}, 1.067 \mathrm{~m}$ and $0.048 \mathrm{~m}$, respectively. It was represented by a single node that was thermally connected to the reactor pool at its exterior and coolant volume 10 at its interior.

\section{Heat structure 102}

Heat structure 102 represents the conical section of the reactor vessel above the core. It is important to point out that the available notes on this structure were incomplete and there appears to be a change made in the notes as to which section of vessel is included and this change only partially propagates through previous RELAP5 models. The original calculations only include the conical section of the vessel while the more recent calculations also include a short section of the reactor core. However, this modification did not include a corresponding reduction of vessel material in the core (heat structure 103). The model described in this document reverts back to the original model to maintain dimensional consistency. The elevation range of this structure was reported as $0.610 \mathrm{~m}$ to $2.930 \mathrm{~m}$ (height $=2.32 \mathrm{~m}$ ). 
This elevation change and the difference in inner radius at its top and bottom $(R=1.067 \mathrm{~m}$ and $r=0.554$ $m$, respectively) were used to obtain the surface area $(A)$ and equivalent radius $\left(R_{\text {eq }}\right)$ :

$$
A=\frac{\pi}{4} \sqrt{(R-r)^{2}+h^{2}}(R+r)=2 \pi R_{e q} h
$$

This results in returning the value of $R_{\text {eq }}$ from $0.786 \mathrm{~m}$ to $0.829 \mathrm{~m}$. The structure was discretized into 5 segments to correspond with the internal and external thermal connections. Also of note, there appears to be a transcription error in the dimensional length of node 2 in previous RELAP5 models since the section of notes summarizing the calculations of the heat structure did not match. The length of node 2 in this current model was changed from $0.784 \mathrm{~m}$ to $0.8532 \mathrm{~m}$ to match the original calculations. Structure 102 is thermally connected to volume $10,8,12$ and 14 at its interior and the reactor pool (volume 100) and the cooling shroud (volume 166) at its exterior. The thickness of this structure was reported as $0.048 \mathrm{~m}$.

\section{$\underline{\text { Heat structure } 103}$}

The cylindrical reactor vessel section within the core region was represented in RELAP5 by heat structure 103. The elevation was reported to be $-0.5892 \mathrm{~m}$ to $+0.6100 \mathrm{~m}$ for a height of $1.1992 \mathrm{~m}$. The inner radius and wall thickness were reported as $0.554 \mathrm{~m}$ and $0.0214 \mathrm{~m}$, respectively. The structure is connected to coolant volumes 14,16 and 18 at its interior and the shroud coolant (volume 166) at its exterior.

\section{Heat structure 104}

Heat structure 104 represents the conical region of the vessel below the core. The elevation of the structure was reported as $-2.101 \mathrm{~m}$ to $-0.5892 \mathrm{~m}$ for a height of $1.512 \mathrm{~m}$. The dimensions for this structure were calculated in the same way as structure 102 and the resulting radius was found to be $0.856 \mathrm{~m}$. The wall thickness was reported as $0.0635 \mathrm{~m}$. The structure connects to volume 24 and part of volume 18 at its interior and the cooling shroud (volume 166) at its exterior. Its axial discretization was based on the fuel and coolant volumes in the core.

\section{$\underline{\text { Heat structure } 105}$}

Structure 105 is the cylindrical section of vessel below the core. Its elevation was reported as $-4.1168 \mathrm{~m}$ to $-2.101 \mathrm{~m}$ for a height of $2.0158 \mathrm{~m}$. Its internal radius and thickness were $1.067 \mathrm{~m}$ and $0.0635 \mathrm{~m}$, respectively. It was connected to volume 24 and 22 at its interior and was partly connected to the cooling shroud at its exterior. The remaining exterior was considered adiabatic.

\section{Heat structure 106}

Heat structure 106 is the lower vessel cover and was represented as fraction of a sphere. It is similar to heat structure 100 except that there were no channel penetrations subtracted from the surface area. This results in slightly larger left boundary or radius $(1.314 \mathrm{~m})$ and smaller sphere fraction $(0.32)$. The structure is in contact with volume 22 at its interior and was considered adiabatic at its outside. 
Table A-1: RELAP5 heat structure description of the reactor vessel components.

\begin{tabular}{|c|c|c|c|c|c|c|c|c|c|c|c|c|c|c|}
\hline \multicolumn{15}{|c|}{ Reactor Vessel } \\
\hline \multicolumn{7}{|c|}{ Geometry } & \multicolumn{4}{|c|}{ Left Boundary data } & \multicolumn{4}{|c|}{ Right Boundary data } \\
\hline $\begin{array}{l}\text { HS } \\
\text { Name }\end{array}$ & Type & $\begin{array}{c}\text { Left } \\
\text { Boundary }\end{array}$ & $\begin{array}{c}\text { Radial } \\
\text { division }\end{array}$ & Thickness & $\begin{array}{c}\text { Right } \\
\text { Boundary }\end{array}$ & Material & Word & $\begin{array}{l}\text { Boundary } \\
\text { Connection }\end{array}$ & Cell & $\begin{array}{l}\text { Geom. } \\
\text { Value }\end{array}$ & Word & $\begin{array}{l}\text { Boundary } \\
\text { Connection }\end{array}$ & Cell & $\begin{array}{l}\text { Geom. } \\
\text { Value }\end{array}$ \\
\hline 100 & Spherical & 1.1730 & 4 & 0.038 & 1.2110 & 9 & 9 & 10 & 1 & 0.3550 & 9 & 100 & 1 & 0.3550 \\
\hline 101 & Cylinder & 1.0670 & 4 & 0.048 & 1.1150 & 2 & 9 & 10 & 1 & 0.4629 & 9 & 100 & 1 & 0.4629 \\
\hline \multirow{5}{*}{102} & \multirow{5}{*}{ Cylinder } & \multirow{5}{*}{0.8290} & \multirow{5}{*}{4} & \multirow{5}{*}{0.048} & \multirow{5}{*}{0.8770} & \multirow{5}{*}{2} & \multirow{5}{*}{9} & 10 & 1 & 0.1108 & \multirow{5}{*}{9} & 100 & 1 & 0.1108 \\
\hline & & & & & & & & 8 & 1 & 0.8532 & & 100 & 1 & 0.8532 \\
\hline & & & & & & & & 8 & 1 & 0.0820 & & 166 & 27 & 0.0820 \\
\hline & & & & & & & & 12 & 1 & 0.8732 & & 166 & 26 & 0.8732 \\
\hline & & & & & & & & 14 & 1 & 0.4010 & & 166 & 25 & 0.4010 \\
\hline \multirow{7}{*}{103} & \multirow{7}{*}{ Cylinder } & \multirow{7}{*}{0.5540} & \multirow{7}{*}{4} & \multirow{7}{*}{0.0214} & \multirow{7}{*}{0.5754} & \multirow{7}{*}{2} & \multirow{7}{*}{9} & 14 & 1 & 0.1528 & \multirow{7}{*}{9} & 166 & 25 & 0.1528 \\
\hline & & & & & & & & 16 & 1 & 0.0762 & & 166 & 24 & 0.0762 \\
\hline & & & & & & & & 16 & 2 & 0.0381 & & 166 & 23 & 0.0381 \\
\hline & & & & & & & & $\ldots$ & & & & & & \\
\hline & & & & & & & & 16 & 21 & 0.0381 & & 166 & 4 & 0.0381 \\
\hline & & & & & & & & 16 & 22 & 0.0762 & & 166 & 3 & 0.0762 \\
\hline & & & & & & & & 18 & 1 & 0.1320 & & 166 & 2 & 0.1320 \\
\hline \multirow[b]{2}{*}{104} & \multirow{2}{*}{ Cylinder } & \multirow{2}{*}{0.8560} & \multirow[b]{2}{*}{5} & \multirow{2}{*}{0.0127} & \multirow{2}{*}{0.9195} & \multirow[b]{2}{*}{2} & \multirow{2}{*}{9} & 18 & 1 & 0.3118 & & 166 & 2 & 0.3118 \\
\hline & & & & & & & & 24 & 1 & 1.2000 & 9 & 166 & 1 & 1.2000 \\
\hline & & & & & & & & 24 & 1 & 0.5322 & & 166 & 1 & 0.5322 \\
\hline 105 & Cylinder & 1.0670 & 5 & 0.0127 & 1.1305 & 2 & 9 & 24 & 1 & 0.2243 & 9 & Symmetry & - & 0.2243 \\
\hline & & & & & & & & 22 & 1 & 1.2593 & & Symmetry & - & 1.2593 \\
\hline 106 & Spherical & 1.3140 & 4 & 0.0095 & 1.3520 & 9 & 9 & 22 & 1 & 0.3200 & 9 & Symmetry & - & 0.3200 \\
\hline
\end{tabular}




\section{A.2 Reactor vessel cooling shroud}

The reactor vessel is cooled in the core region by a separate coolant system that supplies cooling water from the pool. Coolant flows upward along the exterior of the reactor vessel (volume 166) and is discharged back into the pool.

At the time of this document the information for creating this structure was not available.

\section{A.3 Reactor vessel internal structures}

The reactor vessel internal heat structures were labeled 120-220 in the RELAP5 model (Table A-2). They have all been represented as single cell structures.

\section{$\underline{\text { Heat structure } 120}$}

Heat structure 120 represents the flow diffuser (cylinder), deflecting plates and support structures associated with diverting flow from volume 8 up into volume 10 . The specified volume for each of these structures was $0.0536 \mathrm{~m}^{3}, 0.0072 \mathrm{~m}^{3}$ and $0.018 \mathrm{~m}^{3}$, respectively. From this, and the specified height and inner diameter of the flow diffuser $(0.859 \mathrm{~m}$ and $1.550 \mathrm{~m})$, an equivalent structure thickness was calculated to conserve the total mass of the structure. This structure is connected to coolant volume 12 at its interior and coolant volume 8 at exterior.

\section{$\underline{\text { Heat structure } 140}$}

Heat structure 140 is the channel support above the reactor core and was represented by a cylindrical geometry at an elevation of $1.011 \mathrm{~m}$. It was based on design drawing 47123 . The total volume was calculated to be $0.0078 \mathrm{~m}^{3}$ and the inner diameter was specified as $1.165 \mathrm{~m}$. The outer diameter and thickness were calculated to be $1.202 \mathrm{~m}$ and $0.018 \mathrm{~m}$, respectively. The structure was connected to volume 14 at its inside and assumed adiabatic at its outside; both assumed a length of $0.114 \mathrm{~m}$.

\section{Heat structure 201}

Similar to heat structure 140, heat structure 201 is a cylinder representing the channel support below the reactor core. It was based on design plan D2253 \# 47124, 47108 and 47114 . Other than the height of the structure being reported as $0.13 \mathrm{~m}$, there were no further details [in BR2 legacy notes] for describing the geometry of this structure. Because the structure was described as having an upper elevation of $-0.901 \mathrm{~m}$, it was thermally connected to coolant volume 20 . The outer boundary was considered adiabatic. 


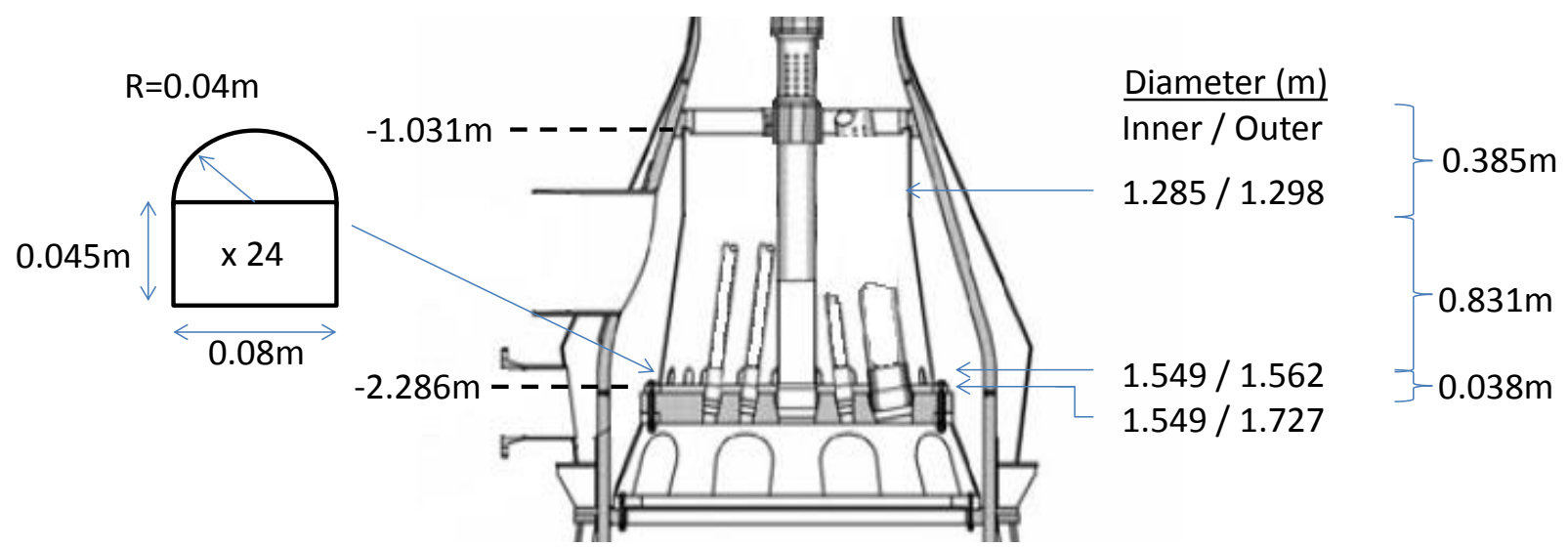

Figure A-1 heat structure 202.

Heat structure 202 represents the outlet flow guide separating volume 20 from volume 24 (Figure A-1). It was based on design plan \#47108. The structure consists of an upper and lower cylindrical section connected by a conical section. There are 24 holes in the lower wall that allow coolant to flow from volume 20 to 24 . The lower and upper elevations are reported as $-2.286 \mathrm{~m}$ and $1.031 \mathrm{~m}$, respectively, with the diameters given in the figure. The inner diameters were used to calculate the total surface area $\left(5.47 \mathrm{~m}^{2}\right)$. The actual length axially along the structure was utilized in the calculation of an equivalent structure radius equal to $0.676 \mathrm{~m}$. Conserving the volume of the structure requires a thickness of $0.00925 \mathrm{~m}$, however, the actual thickness of the structure is $0.00635 \mathrm{~m}$. Instead, the thickness was preserved and a new equivalent length of $1.882 \mathrm{~m}$ was calculated. It should be noted that the there was an error in the previous RELAP5 model since the length $(1.882 \mathrm{~m})$ was used in specifying the radius instead of $0.676 \mathrm{~m}$. 


\section{Heat structure 203}

Heat structure 203 represents the channel support structure below heat structure 202 and was based on design drawing D2253 \# 47113. The lower and upper elevation was reported as $-2.4384 \mathrm{~m}$ and $-2.286 \mathrm{~m}$, respectively. The structure was modeled as a rectangular plate that is thermally connected to volumes 20 and 22 . The plate contains through holes recessed $0.1016 \mathrm{~m}$ to position and support the support tubes (channels). Subtracting the hole volumes $\left(0.115 \mathrm{~m}^{3}\right)$ from the plate volume $\left(0.378 \mathrm{~m}^{3}\right)$ and dividing this by the plate thickness $(0.152 \mathrm{~m})$ results in a surface area of $1.73 \mathrm{~m}^{2}$.

Heat structure 220

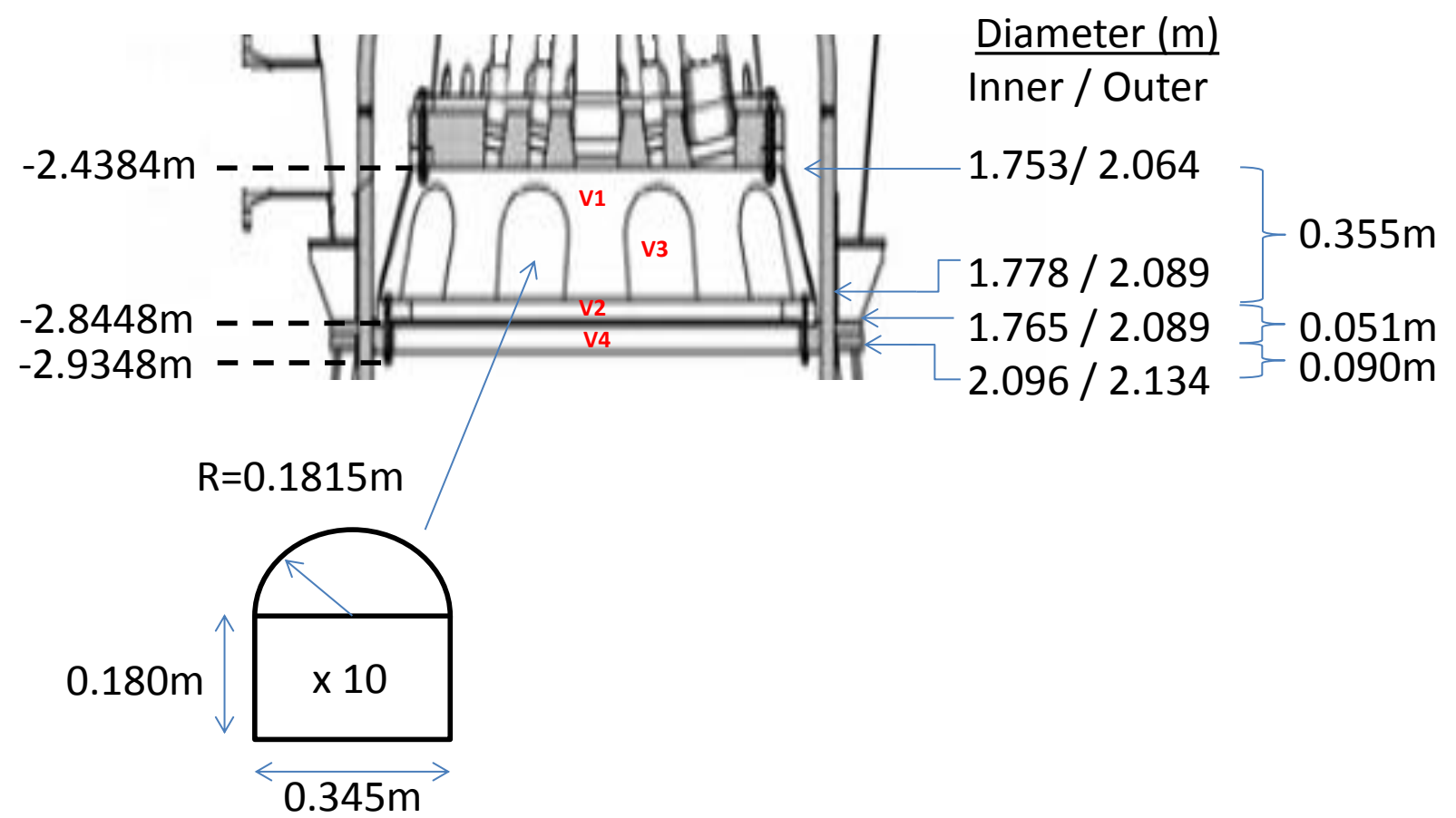

Figure A-2 heat structure 220.

Heat structure 220 represents the support plate component between volumes 22 and 24 and was modeled as a cylinder. Two references were listed for this component: D2253 plan \#47112 and D2252 plan \#47108 section EE. The structure consists of conical section with 10 holes as well as a ring and ring support. The total volume was $0.0920 \mathrm{~m}^{3}(\mathrm{~V} 1+\mathrm{V} 2-\mathrm{V} 3+\mathrm{V} 4=0.028+0.0498-0.0145+0.03)$. The diameter and thickness of the structure were specified as $1.908 \mathrm{~m}$ and $0.0127 \mathrm{~m}$, respectively. Conserving the volume of the structure, the hydraulic diameter and thickness were used to calculate a cylinder height of $1.196 \mathrm{~m}$. 
Table A-2: RELAP5 description of reactor vessel internal structures.

\begin{tabular}{|c|c|c|c|c|c|c|c|c|c|c|c|c|c|c|}
\hline \multicolumn{15}{|c|}{ Reactor vessel internal structures } \\
\hline \multicolumn{7}{|c|}{ Geometry } & \multicolumn{4}{|c|}{ Left Boundary data } & \multicolumn{4}{|c|}{ Right Boundary data } \\
\hline $\begin{array}{c}\text { HS } \\
\text { Name }\end{array}$ & Type & $\begin{array}{c}\text { Left } \\
\text { Boundary }\end{array}$ & $\begin{array}{c}\text { Radial } \\
\text { division }\end{array}$ & $\begin{array}{l}\text { Unit } \\
\text { Thick }\end{array}$ & $\begin{array}{c}\text { Right } \\
\text { Boundary }\end{array}$ & Material & Word & $\begin{array}{c}\text { Boundary } \\
\text { Connection }\end{array}$ & Cell & $\begin{array}{l}\text { Geom. } \\
\text { Value }\end{array}$ & Word & $\begin{array}{c}\text { Boundary } \\
\text { Connection }\end{array}$ & Cell & $\begin{array}{l}\text { Geom. } \\
\text { Value }\end{array}$ \\
\hline 120 & Cylinder & 0.7750 & 3 & 0.0570 & 0.8320 & 2 & 9 & 12 & 1 & 0.8590 & 9 & 8 & 1 & 0.8590 \\
\hline 140 & Cylinder & 0.5830 & 3 & 0.1850 & 0.6015 & 9 & 9 & 14 & 1 & 0.1140 & 9 & Symmetry & - & 0.1140 \\
\hline 201 & Cylinder & 0.5830 & 3 & 0.0445 & 0.6275 & 9 & 9 & 20 & 1 & 0.1300 & 9 & Symmetry & - & 0.1300 \\
\hline 202 & Cylinder & 0.6760 & 3 & 0.0064 & 0.6824 & 9 & 9 & 20 & 1 & 1.8820 & 9 & 24 & 1 & 1.8820 \\
\hline 203 & Rectangle & 0.0000 & 3 & 0.1520 & 0.1520 & 9 & 9 & 20 & 1 & 1.7300 & 9 & 22 & 1 & 1.7300 \\
\hline 220 & Cylinder & 0.9540 & 3 & 0.0127 & 0.9667 & 9 & 9 & 22 & 1 & 1.1960 & 9 & 24 & 1 & 1.1960 \\
\hline
\end{tabular}

\section{A.4 Reactor channels}

Three types of reactor channels $(50 \mathrm{~mm}, 84 \mathrm{~mm}$ and $200 \mathrm{~mm}$ ) are used in the BR2 reactor. The parameters given in the following tables were used in the calculation of the channel heat structures. Because of the hyperboloid configuration, channel elevations in BR2 are slightly different for each of the 79 channels. In the RELAP5 model, the upper and lower elevations for each channel have been slightly adjusted since the model assumes all channels to be vertical. The detailed data describing the geometry of the channels has been volume averaged into 6 sections corresponding to the coolant volume regions.

Table A-3: $50 \mathrm{~mm}$ channel dimensions

\begin{tabular}{|c|c|c|c|c|c|c|c|c|c|c|}
\hline \multicolumn{6}{|c|}{ Data } & \multicolumn{5}{|c|}{ Volume Averaged } \\
\hline $\begin{array}{l}\text { Lower } \\
\text { elevation }\end{array}$ & $\begin{array}{c}\text { Upper } \\
\text { elevation }\end{array}$ & $\begin{array}{c}\text { Inner } \\
\text { Diameter }\end{array}$ & $\begin{array}{c}\text { Outer } \\
\text { Diameter }\end{array}$ & $\begin{array}{c}\text { Hole } \\
\#\end{array}$ & $\begin{array}{l}\text { Hole } \\
\text { Diam. }\end{array}$ & Length & $\begin{array}{c}\text { Inner } \\
\text { Diameter }\end{array}$ & $\begin{array}{c}\text { Outer } \\
\text { Diameter }\end{array}$ & $\begin{array}{l}\text { Structure } \\
\text { Volume }\end{array}$ & $\begin{array}{c}\text { Material } \\
\#\end{array}$ \\
\hline$[\mathrm{mm}]$ & {$[\mathrm{mm}]$} & {$[\mathrm{mm}]$} & {$[\mathrm{mm}]$} & & {$[\mathrm{mm}]$} & {$[\mathrm{mm}]$} & {$[\mathrm{mm}]$} & {$[\mathrm{mm}]$} & {$\left[\mathrm{m}^{3}\right]$} & \\
\hline 2819.2 & 4421.9 & 63.4 & 66.7 & 0 & 0 & 1602.7 & \multirow{12}{*}{61.5} & \multirow{12}{*}{67.4} & $5.30 e-4$ & \multirow{12}{*}{9} \\
\hline 2620.9 & 2819.2 & 63.4 & 66.7 & 0 & 0 & \multirow{5}{*}{1808.2} & & & \multirow{5}{*}{$7.40 \mathrm{e}-4$} & \\
\hline 1142.0 & 2620.9 & 63.4 & 66.7 & 480 & 6.35 & & & & & \\
\hline 1092.0 & 1142.0 & 58.8 & 62.0 & 0 & 0 & & & & & \\
\hline 1048.4 & 1092.0 & 54.1 & 63.5 & 0 & 0 & & & & & \\
\hline 1011.0 & 1048.4 & 54.1 & 90.8 & 0 & 0 & & & & & \\
\hline 998.4 & 1011.0 & 54.1 & 90.8 & 0 & 0 & \multirow{6}{*}{553.8} & & & \multirow{6}{*}{$1.05 e-3$} & \\
\hline 898.6 & 998.4 & 52.1 & 90.8 & 0 & 0 & & & & & \\
\hline 876.7 & 898.6 & 50.1 & 90.8 & 0 & 0 & & & & & \\
\hline 698.7 & 876.7 & 50.1 & 56.8 & 30 & 6.35 & & & & & \\
\hline 518.0 & 698.7 & 50.1 & 56.8 & 30 & 6.35 & & & & & \\
\hline 457.2 & 518.0 & 50.1 & 90.8 & 0 & 0 & & & & & \\
\hline-457.2 & 457.2 & 50.1 & 100.9 & 0 & 0 & 914.4 & 50.1 & 100.9 & $5.51 \mathrm{e}-3$ & 7 or 8 \\
\hline-518.0 & -457.2 & 50.1 & 90.8 & 0 & 0 & & & & & \\
\hline-698.7 & -518.0 & 50.1 & 56.8 & 30 & 6.35 & 4438 & & & $5.78 \mathrm{e}-4$ & \\
\hline-876.8 & -698.7 & 50.1 & 56.8 & 30 & 6.35 & 443.8 & & & $3 . / 8 \mathrm{e}-4$ & \\
\hline-901.0 & -876.8 & 50.1 & 90.8 & 0 & 0 & & 47.4 & 58.9 & & 9 \\
\hline-1041.5 & -901.0 & 50.1 & 90.8 & 0 & 0 & & & & & \\
\hline-2325.2 & -1041.5 & 47.2 & 54.0 & 0 & 0 & 1537.5 & & & $1.33 e-3$ & \\
\hline-2438.5 & -2325.2 & 34.9 & 34.9 & 0 & 0 & & & & & \\
\hline
\end{tabular}


Table A-4: $84 \mathrm{~mm}$ channel dimensions

\begin{tabular}{|c|c|c|c|c|c|c|c|c|c|c|}
\hline \multicolumn{6}{|c|}{ Raw Data } & \multicolumn{5}{|c|}{ Volume Averaged } \\
\hline $\begin{array}{c}\text { Lower } \\
\text { elevation }\end{array}$ & $\begin{array}{c}\text { Upper } \\
\text { elevation }\end{array}$ & $\begin{array}{c}\text { Inner } \\
\text { Diameter }\end{array}$ & $\begin{array}{c}\text { Outer } \\
\text { Diameter }\end{array}$ & $\begin{array}{c}\text { Hole } \\
\#\end{array}$ & $\begin{array}{l}\text { Hole } \\
\text { Diam. }\end{array}$ & Length & $\begin{array}{c}\text { Inner } \\
\text { Diameter }\end{array}$ & $\begin{array}{c}\text { Outer } \\
\text { Diameter }\end{array}$ & $\begin{array}{l}\text { Structure } \\
\text { Volume }\end{array}$ & $\begin{array}{c}\text { Material } \\
\#\end{array}$ \\
\hline$[\mathrm{mm}]$ & {$[\mathrm{mm}]$} & {$[\mathrm{mm}]$} & {$[\mathrm{mm}]$} & & {$[\mathrm{mm}]$} & {$[\mathrm{mm}]$} & {$[\mathrm{mm}]$} & {$[\mathrm{mm}]$} & {$\left[\mathrm{m}^{3}\right]$} & \\
\hline 4290.9 & 4421.9 & 92.1 & 95.3 & 0 & 0 & & \multirow{14}{*}{90.8} & \multirow{14}{*}{95.1} & \multirow{2}{*}{$7.49 e-4$} & \multirow{14}{*}{9} \\
\hline 2819.1 & 4290.9 & 92.1 & 95.3 & 0 & 0 & 1597.3 & & & & \\
\hline 2668.1 & 2819.1 & 92.1 & 95.3 & 0 & 0 & \multirow{4}{*}{1808.1} & & & \multirow{4}{*}{$9.57 e-4$} & \\
\hline 1165.3 & 2668.1 & 92.1 & 95.3 & 480 & 6.35 & & & & & \\
\hline 1058.4 & 1165.3 & 88.9 & 95.3 & 0 & 0 & & & & & \\
\hline 1011.0 & 1058.4 & 84.2 & 100.3 & 0 & 0 & & & & & \\
\hline 860.0 & 1011.0 & 84.2 & 100.3 & 0 & 0 & \multirow{8}{*}{553.8} & & & \multirow{8}{*}{ 7.71e-4 } & \\
\hline 765.5 & 860.0 & 84.2 & 90.5 & 24 & 4.76 & & & & & \\
\hline 698.5 & 765.5 & 84.2 & 90.5 & 12 & 4.76 & & & & & \\
\hline 672.7 & 698.5 & 84.2 & 90.5 & 6 & 4.76 & & & & & \\
\hline 621.1 & 672.7 & 84.2 & 90.5 & 12 & 4.76 & & & & & \\
\hline 576.4 & 621.1 & 84.2 & 90.5 & 6 & 4.76 & & & & & \\
\hline 508.5 & 576.4 & 84.2 & 90.5 & 0 & 0 & & & & & \\
\hline 457.2 & 508.5 & 84.2 & 100.3 & 0 & 0 & & & & & \\
\hline-457.2 & 457.2 & 84.2 & 100.9 & 0 & 0 & 914.4 & 84.2 & 100.9 & $2.22 \mathrm{e}-3$ & 7 or 8 \\
\hline-508.5 & -457.2 & 84.2 & 100.3 & 0 & 0 & \multirow{8}{*}{443.8} & \multirow{11}{*}{80.5} & \multirow{11}{*}{92.0} & \multirow{8}{*}{$5.43 e-4$} & \multirow{11}{*}{9} \\
\hline-576.4 & -508.5 & 84.2 & 90.5 & 0 & 0 & & & & & \\
\hline-621.1 & -576.4 & 84.2 & 90.5 & 12 & 6.35 & & & & & \\
\hline-672.7 & -621.1 & 84.2 & 90.5 & 12 & 6.35 & & & & & \\
\hline-698.5 & -672.4 & 84.2 & 90.5 & 12 & 6.35 & & & & & \\
\hline-765.0 & -698.5 & 84.2 & 90.5 & 12 & 6.35 & & & & & \\
\hline-855.4 & -765.0 & 84.2 & 90.5 & 12 & 6.35 & & & & & \\
\hline-901.0 & -855.4 & 80.1 & 100.3 & 0 & 0 & & & & & \\
\hline-1053.9 & -901.0 & 80.1 & 100.3 & 0 & 0 & \multirow{3}{*}{1537.5} & & & \multirow{3}{*}{$2.53 e-3$} & \\
\hline-2348.9 & -1053.9 & 80.1 & 92.1 & 0 & 0 & & & & & \\
\hline-2438.4 & -2348.9 & 69.9 & 69.9 & 0 & 0 & & & & & \\
\hline
\end{tabular}

Table A-5: $200 \mathrm{~mm}$ channel dimensions

\begin{tabular}{|c|c|c|c|c|c|c|c|c|c|c|}
\hline \multicolumn{6}{|c|}{ Raw Data } & \multicolumn{5}{|c|}{ Volume Averaged } \\
\hline $\begin{array}{l}\text { Lower } \\
\text { elevation }\end{array}$ & $\begin{array}{c}\text { Upper } \\
\text { elevation }\end{array}$ & $\begin{array}{c}\text { Inner } \\
\text { Diameter }\end{array}$ & $\begin{array}{c}\text { Outer } \\
\text { Diameter }\end{array}$ & $\begin{array}{c}\text { Hole } \\
\#\end{array}$ & $\begin{array}{l}\text { Hole } \\
\text { Diam. }\end{array}$ & Length & $\begin{array}{c}\text { Inner } \\
\text { Diameter }\end{array}$ & $\begin{array}{c}\text { Outer } \\
\text { Diameter }\end{array}$ & $\begin{array}{l}\text { Structure } \\
\text { Volume }\end{array}$ & $\begin{array}{c}\text { Material } \\
\#\end{array}$ \\
\hline$[\mathrm{mm}]$ & {$[\mathrm{mm}]$} & {$[\mathrm{mm}]$} & {$[\mathrm{mm}]$} & & {$[\mathrm{mm}]$} & {$[\mathrm{mm}]$} & {$[\mathrm{mm}]$} & {$[\mathrm{mm}]$} & {$\left[\mathrm{m}^{3}\right]$} & \\
\hline 2819.2 & 4421.9 & 215.9 & 228.6 & 0 & 0 & 1772.1 & \multirow{14}{*}{214.4} & \multirow{14}{*}{232.2} & 7.11e-3 & \multirow{14}{*}{9} \\
\hline 2565.3 & 2819.2 & 215.9 & 228.6 & 0 & 0 & & & & \multirow{7}{*}{$9.16 e-3$} & \\
\hline 2320.8 & 2565.3 & 215.9 & 228.6 & 234 & 6.35 & & & & & \\
\hline 1981.2 & 2320.8 & 215.9 & 228.6 & 342 & 6.35 & & & & & \\
\hline 1886.9 & 1981.2 & 215.9 & 228.6 & 0 & 0 & 1808.2 & & & & \\
\hline 1075.5 & 1886.9 & 215.9 & 228.6 & 792 & 6.35 & & & & & \\
\hline 1056.6 & 1075.5 & 215.9 & 228.6 & 0 & 0 & & & & & \\
\hline 1011.0 & 1056.6 & 215.9 & 303.2 & 0 & 0 & & & & & \\
\hline 981.2 & 1011.0 & 215.9 & 303.2 & 0 & 0 & \multirow{6}{*}{553.8} & & & \multirow{6}{*}{$8.80 e-3$} & \\
\hline 943.4 & 981.2 & 209.5 & 303.2 & 0 & 0 & & & & & \\
\hline 861.7 & 943.4 & 203.6 & 303.2 & 0 & 0 & & & & & \\
\hline 732.8 & 861.7 & 203.6 & 215.9 & 132 & 6.35 & & & & & \\
\hline 534.6 & 732.8 & 203.6 & 215.9 & 198 & 6.35 & & & & & \\
\hline 457.2 & 534.6 & 203.6 & 266.9 & 0 & 0 & & & & & \\
\hline-457.2 & 457.2 & 203.6 & 266.9 & 0 & 0 & 914.4 & 203.6 & 266.9 & $2.14 \mathrm{e}-2$ & 7 or 8 \\
\hline-534.6 & -457.2 & 203.6 & 266.9 & 0 & 0 & \multirow{4}{*}{443.8} & \multirow{7}{*}{203.6} & \multirow{7}{*}{227.5} & \multirow{4}{*}{$4.24 \mathrm{e}-3$} & \multirow{7}{*}{9} \\
\hline-650.9 & -534.6 & 203.6 & 215.9 & 0 & 0 & & & & & \\
\hline-713.8 & -650.9 & 203.6 & 215.9 & 132 & 6.35 & & & & & \\
\hline-872.6 & -713.8 & 203.6 & 215.9 & 198 & 6.35 & & & & & \\
\hline-901.0 & -872.6 & 203.6 & 303.2 & 0 & 0 & \multirow{3}{*}{1537.4} & & & \multirow{3}{*}{$1.18 \mathrm{e}-2$} & \\
\hline-1056.6 & -901.0 & 203.6 & 303.2 & 0 & 0 & & & & & \\
\hline-2438.5 & -1056.6 & 203.6 & 215.9 & 0 & 0 & & & & & \\
\hline
\end{tabular}




\section{A.5 Reactor channel internals}

This section describes the geometry of the reactor channel internals used in the calculations to obtain the RELAP5 heat structures described in the following section. The core region (-457.2 to 457.2 ) is based on the information provided in reference [4].

\section{Plug in $50 \mathrm{~mm}$ channel}

This plug was assumed to be constructed of the same material within each elevation.

Table A-6: Plug in $\mathbf{5 0 ~} \mathbf{m m}$ channel

\begin{tabular}{|c|c|c|c|}
\hline $\begin{array}{c}\text { Lower } \\
\text { elevation }\end{array}$ & $\begin{array}{c}\text { Upper } \\
\text { elevation }\end{array}$ & Diameter & $\begin{array}{c}\text { Structure } \\
\text { Volume }\end{array}$ \\
\hline$[\mathrm{mm}]$ & {$[\mathrm{mm}]$} & {$[\mathrm{mm}]$} & {$\left[\mathrm{m}^{3}\right]$} \\
\hline 2819.2 & 4421.9 & 25.4 & $8.12 e-4$ \\
\hline 2620.9 & 2819.2 & 25.4 & \multirow{5}{*}{$9.16 \mathrm{e}-4$} \\
\hline 1142.0 & 2620.9 & 25.4 & \\
\hline 1092.0 & 1142.0 & 25.4 & \\
\hline 1048.4 & 1092.0 & 25.4 & \\
\hline 1011.0 & 1048.4 & 25.4 & \\
\hline 998.4 & 1011.0 & 25.4 & \multirow{6}{*}{$5.60 \mathrm{e}-4$} \\
\hline 898.6 & 998.4 & 25.4 & \\
\hline 876.7 & 898.6 & 25.4 & \\
\hline 698.7 & 876.7 & 25.4 & \\
\hline 518.0 & 698.7 & 46.0 & \\
\hline 457.2 & 518.0 & 46.0 & \\
\hline-457.2 & 457.2 & 46.0 & $1.52 \mathrm{e}-3$ \\
\hline-518.0 & -457.2 & 46.0 & \multirow{2}{*}{$4.02 \mathrm{e}-4$} \\
\hline-698.7 & -518.0 & 46.0 & \\
\hline
\end{tabular}

\section{Plug in $84 \mathrm{~mm}$ channel}

This plug was assumed to be constructed of the same material within each elevation.

Table A-7: Beryllium plug in $84 \mathrm{~mm}$ channel

\begin{tabular}{|c|c|c|c|c|c|c|c|c|}
\hline & & \multicolumn{2}{|c|}{ Pin and plug } & \multicolumn{5}{|c|}{ Support tube and plug } \\
\hline $\begin{array}{c}\text { Lower } \\
\text { elevation }\end{array}$ & $\begin{array}{c}\text { Upper } \\
\text { elevation }\end{array}$ & Diameter & $\begin{array}{l}\text { Structure } \\
\text { Volume }\end{array}$ & $\begin{array}{c}\text { Inner } \\
\text { Diameter }\end{array}$ & $\begin{array}{c}\text { Outer } \\
\text { Diameter }\end{array}$ & $\begin{array}{c}\text { \# of } \\
\text { Holes }\end{array}$ & $\begin{array}{c}\text { Hole } \\
\text { Diameter }\end{array}$ & $\begin{array}{l}\text { Structure } \\
\text { Volume }\end{array}$ \\
\hline$[\mathrm{mm}]$ & {$[\mathrm{mm}]$} & {$[\mathrm{mm}]$} & {$\left[\mathrm{m}^{3}\right]$} & {$[\mathrm{mm}]$} & {$[\mathrm{mm}]$} & & {$[\mathrm{mm}]$} & {$\left[\mathrm{m}^{3}\right]$} \\
\hline 2819.1 & 4421.9 & 25.4 & $8.12 \mathrm{e}-4$ & 34.9 & 44.5 & & & $9.52 \mathrm{e}-4$ \\
\hline 2668.1 & 2819.1 & 25.4 & \multirow{4}{*}{$9.16 \mathrm{e}-4$} & 34.9 & 44.5 & & & \multirow{4}{*}{$1.07 e-3$} \\
\hline 1175.0 & 2668.1 & 25.4 & & 34.9 & 44.5 & 10 & 6.35 & \\
\hline 1058.4 & 1175.0 & 25.4 & & 34.9 & 44.5 & & & \\
\hline 1011.0 & 1058.4 & 25.4 & & 34.9 & 44.5 & & & \\
\hline 860.0 & 1011.0 & 25.4 & \multirow{5}{*}{$3.09 \mathrm{e}-4$} & 34.9 & 44.5 & & & \multirow{5}{*}{$1.04 \mathrm{e}-3$} \\
\hline 653.6 & 860.0 & 25.4 & & 34.9 & 44.5 & & & \\
\hline 604.8 & 653.6 & 29.8 & & 34.9 & 80.6 & & & \\
\hline 516.6 & 604.8 & 29.8 & & 33.5 & 80.6 & & & \\
\hline 457.2 & 516.6 & 29.8 & & 33.5 & 80.6 & & & \\
\hline-457.2 & 457.2 & 29.8 & $6.36 e-4$ & 33.5 & 80.6 & & & $3.87 e-3$ \\
\hline-516.6 & -457.2 & 29.8 & \multirow{2}{*}{$1.29 \mathrm{e}-4$} & 33.5 & 80.6 & & & \multirow{2}{*}{$7.84 \mathrm{e}-4$} \\
\hline-642.6 & -516.6 & 29.8 & & 33.5 & 80.6 & & & \\
\hline
\end{tabular}

Plug in $200 \mathrm{~mm}$ channel 
Within the matrix, the $200 \mathrm{~mm}$ plug contains a large beryllium plug that contains within it 3 of the plugs used in the $84 \mathrm{~mm}$ channel. Outside of the matrix region this channel contains additional guide tubes and structure.

Table A-8: $200 \mathrm{~mm}$ flow channel with plugs. There are three $84 \mathrm{~mm}$ plug channels modeled as described above.

\begin{tabular}{|c|c|c|c|c|c|c|c|c|c|}
\hline & & \multicolumn{2}{|c|}{3 outer plugs and support structure } & \multicolumn{6}{|c|}{ Guide tubes and large Be piece } \\
\hline $\begin{array}{c}\text { Lower } \\
\text { elevation }\end{array}$ & $\begin{array}{c}\text { Upper } \\
\text { elevation }\end{array}$ & Inner Diameter & Outer Diameter & $\begin{array}{c}\text { Inner } \\
\text { Diameter }\end{array}$ & $\begin{array}{c}\text { Outer } \\
\text { Diameter }\end{array}$ & $\begin{array}{l}\text { \# of } \\
\text { Holes }\end{array}$ & $\begin{array}{c}\text { Hole } \\
\text { Diameter }\end{array}$ & $\begin{array}{l}\text { Structure } \\
\text { Volume }\end{array}$ & $\begin{array}{c}\text { Material } \\
\#\end{array}$ \\
\hline$[\mathrm{mm}]$ & {$[\mathrm{mm}]$} & {$[\mathrm{mm}]$} & {$[\mathrm{mm}]$} & {$[\mathrm{mm}]$} & {$[\mathrm{mm}]$} & & {$[\mathrm{mm}]$} & {$\left[\mathrm{m}^{3}\right]$} & \\
\hline 2819.2 & 4421.9 & \multirow{12}{*}{$15.9 / 34.9$} & \multirow{12}{*}{$25.4 / 44.5$} & 85.6 & 88.9 & 468 & 6.35 & $7.44 \mathrm{e}-3$ & \multirow{14}{*}{2} \\
\hline 2565.3 & 2819.2 & & & 85.6 & 88.9 & 66 & 6.35 & \multirow{7}{*}{$8.42 \mathrm{e}-3$} & \\
\hline 2320.8 & 2565.3 & & & 85.6 & 88.9 & 66 & 6.35 & & \\
\hline 1981.2 & 2320.8 & & & 85.6 & 88.9 & & & & \\
\hline 1886.9 & 1981.2 & & & 85.6 & 88.9 & & & & \\
\hline 1075.5 & 1886.9 & & & 85.6 & 88.9 & & & & \\
\hline 1056.6 & 1075.5 & & & 85.6 & 88.9 & & & & \\
\hline 1011.0 & 1056.6 & & & 85.6 & 88.9 & & & & \\
\hline 981.2 & 1011.0 & & & 85.6 & 88.9 & & & \multirow{6}{*}{$9.44 \mathrm{e}-3$} & \\
\hline 943.4 & 981.2 & & & 85.6 & 88.9 & & & & \\
\hline 861.7 & 943.4 & & & 85.6 & 88.9 & & & & \\
\hline 732.8 & 861.7 & & & 85.6 & 88.9 & & & & \\
\hline 534.6 & 732.8 & \multirow{2}{*}{$0 / 33.5$} & \multirow{2}{*}{$29.8 / 80.6$} & 150.4 & 203.6 & & & & \\
\hline 457.2 & 534.6 & & & 150.4 & 203.6 & & & & \\
\hline-457.2 & 457.2 & \multirow{3}{*}{$0 / 33.3$} & \multirow{3}{*}{$29.8 / 80.6$} & 150.4 & 203.6 & & & $2.7 \mathrm{e}-2$ & 7 or 8 \\
\hline-534.6 & -457.2 & & & 150.4 & 203.6 & & & \multirow{3}{*}{$6.66 e-3$} & \multirow{3}{*}{2} \\
\hline-650.9 & -534.6 & & & 150.4 & 203.6 & & & & \\
\hline-713.8 & -650.9 & & & 150.4 & 203.6 & & & & \\
\hline
\end{tabular}

\section{Control rod in $84 \mathrm{~mm}$ channel}

It was assumed that half the matrix height was control rod and the other half follower.

Table A-9: Control rod in $84 \mathrm{~mm}$ channel

\begin{tabular}{|c|c|c|c|c|c|c|c|c|c|c|}
\hline & & \multicolumn{3}{|c|}{ Pin and follower } & \multicolumn{6}{|c|}{ Support tube and control rod } \\
\hline $\begin{array}{c}\text { Lower } \\
\text { elevation }\end{array}$ & $\begin{array}{c}\text { Upper } \\
\text { elevation }\end{array}$ & Diameter & $\begin{array}{l}\text { Structure } \\
\text { Volume }\end{array}$ & $\begin{array}{c}\text { Material } \\
\#\end{array}$ & $\begin{array}{c}\text { Inner } \\
\text { Diameter }\end{array}$ & $\begin{array}{c}\text { Outer } \\
\text { Diameter }\end{array}$ & $\begin{array}{c}\text { \# of } \\
\text { Holes }\end{array}$ & $\begin{array}{c}\text { Hole } \\
\text { Diameter }\end{array}$ & $\begin{array}{c}\text { Structure } \\
\text { Volume }\end{array}$ & $\begin{array}{c}\text { Material } \\
\#\end{array}$ \\
\hline$[\mathrm{mm}]$ & {$[\mathrm{mm}]$} & {$[\mathrm{mm}]$} & {$\left[\mathrm{m}^{3}\right]$} & & {$[\mathrm{mm}]$} & {$[\mathrm{mm}]$} & & {$[\mathrm{mm}]$} & {$\left[\mathrm{m}^{3}\right]$} & \\
\hline 2819.1 & 4421.9 & 25.4 & $8.12 \mathrm{e}-4$ & \multirow{11}{*}{2} & 34.9 & 44.5 & & & $9.52 \mathrm{e}-4$ & \multirow{14}{*}{2} \\
\hline 2668.1 & 2819.1 & 25.4 & \multirow{4}{*}{$9.16 \mathrm{e}-4$} & & 34.9 & 44.5 & & & \multirow{4}{*}{$1.07 e-3$} & \\
\hline 1175.0 & 2668.1 & 25.4 & & & 34.9 & 44.5 & 10 & 6.35 & & \\
\hline 1058.4 & 1175.0 & 25.4 & & & 34.9 & 44.5 & & & & \\
\hline 1011.0 & 1058.4 & 25.4 & & & 34.9 & 44.5 & & & & \\
\hline 860.0 & 1011.0 & 25.4 & \multirow{5}{*}{$3.09 e-4$} & & 34.9 & 44.5 & & & \multirow{5}{*}{$1.04 \mathrm{e}-3$} & \\
\hline 653.6 & 860.0 & 25.4 & & & 34.9 & 44.5 & & & & \\
\hline 604.8 & 653.6 & 29.8 & & & 34.9 & 80.6 & & & & \\
\hline 516.6 & 604.8 & 29.8 & & & 33.5 & 80.6 & & & & \\
\hline 457.2 & 516.6 & 29.8 & & & 33.5 & 80.6 & & & & \\
\hline 0 & 457.2 & 0 & 0 & & 48 & 75.9 & & & $1.47 \mathrm{e}-3$ & \\
\hline-457.2 & 0 & 52.0 & $9.71 \mathrm{e}-4$ & 7 or 8 & 58 & 75.9 & & & $8.61 \mathrm{e}-3$ & \\
\hline-516.6 & -457.2 & 29.8 & \multirow{2}{*}{$1.29 \mathrm{e}-4$} & \multirow{2}{*}{2} & 33.5 & 80.6 & & & \multirow{2}{*}{$7.84 \mathrm{e}-4$} & \\
\hline-642.6 & -516.6 & 29.8 & & & 33.5 & 80.6 & & & & \\
\hline
\end{tabular}




\section{$\underline{\mathrm{PRF} \text { in } 84 \mathrm{~mm} \text { channel }}$}

Within the matrix, the structure with a diameter of $60.5 \mathrm{~mm}$ is $40 \%$ water.

Table A-10: PRF in 84 mm channel

\begin{tabular}{|c|c|c|c|c|c|c|c|c|c|c|}
\hline & & \multicolumn{3}{|c|}{ Al pin or Be inner plug } & \multicolumn{6}{|c|}{ Support tube or Be outer plug } \\
\hline $\begin{array}{c}\text { Lower } \\
\text { elevation }\end{array}$ & $\begin{array}{c}\text { Upper } \\
\text { elevation }\end{array}$ & Diameter & $\begin{array}{l}\text { Structure } \\
\text { Volume }\end{array}$ & $\begin{array}{c}\text { Material } \\
\# \\
\end{array}$ & $\begin{array}{c}\text { Inner } \\
\text { Diameter }\end{array}$ & $\begin{array}{c}\text { Outer } \\
\text { Diameter }\end{array}$ & $\begin{array}{c}\text { \# of } \\
\text { Holes }\end{array}$ & $\begin{array}{c}\text { Hole } \\
\text { Diameter }\end{array}$ & $\begin{array}{l}\text { Structure } \\
\text { Volume }\end{array}$ & $\begin{array}{c}\text { Material } \\
\#\end{array}$ \\
\hline$[\mathrm{mm}]$ & {$[\mathrm{mm}]$} & {$[\mathrm{mm}]$} & {$\left[\mathrm{m}^{3}\right]$} & & {$[\mathrm{mm}]$} & {$[\mathrm{mm}]$} & & {$[\mathrm{mm}]$} & {$\left[\mathrm{m}^{3}\right]$} & \\
\hline 2819.1 & 4421.9 & 25.4 & $8.12 \mathrm{e}-4$ & \multirow{10}{*}{2} & 34.9 & 44.5 & & & $9.52 \mathrm{e}-4$ & \multirow{10}{*}{2} \\
\hline 2668.1 & 2819.1 & 25.4 & \multirow{4}{*}{$9.16 \mathrm{e}-4$} & & 34.9 & 44.5 & & & \multirow{4}{*}{$1.07 e-3$} & \\
\hline 1175.0 & 2668.1 & 25.4 & & & 34.9 & 44.5 & 10 & 6.35 & & \\
\hline 1058.4 & 1175.0 & 25.4 & & & 34.9 & 44.5 & & & & \\
\hline 1011.0 & 1058.4 & 25.4 & & & 34.9 & 44.5 & & & & \\
\hline 860.0 & 1011.0 & 25.4 & \multirow{5}{*}{$3.09 e-4$} & & 34.9 & 44.5 & & & \multirow{5}{*}{$1.04 \mathrm{e}-3$} & \\
\hline 653.6 & 860.0 & 25.4 & & & 34.9 & 44.5 & & & & \\
\hline 604.8 & 653.6 & 25.4 & & & 34.9 & 80.6 & & & & \\
\hline 516.6 & 604.8 & 29.8 & & & 33.5 & 80.6 & & & & \\
\hline 457.2 & 516.6 & 29.8 & & & 33.5 & 80.6 & & & & \\
\hline-457.2 & 457.2 & 0 & 0 & & 75,62 & $\begin{array}{c}80,70 \\
60.5\end{array}$ & & & $2.89 e-3$ & 7 or 8 \\
\hline-516.6 & -457.2 & 29.8 & \multirow{2}{*}{$1.29 \mathrm{e}-4$} & \multirow{2}{*}{2} & 33.5 & 80.6 & & & & \multirow{2}{*}{2} \\
\hline-642.6 & -516.6 & 29.8 & & & 33.5 & 80.6 & & & & \\
\hline
\end{tabular}

\section{DG in $84 \mathrm{~mm}$ channel}

Table A-11: DG in $84 \mathrm{~mm}$ channel

\begin{tabular}{|c|c|c|c|c|}
\hline & & \multicolumn{3}{|c|}{ DG Internals } \\
\hline $\begin{array}{c}\text { Lower } \\
\text { elevation }\end{array}$ & $\begin{array}{c}\text { Upper } \\
\text { elevation }\end{array}$ & Diameter & $\begin{array}{l}\text { Structure } \\
\text { Volume }\end{array}$ & $\begin{array}{c}\text { Material } \\
\#\end{array}$ \\
\hline$[\mathrm{mm}]$ & {$[\mathrm{mm}]$} & {$[\mathrm{mm}]$} & {$\left[\mathrm{m}^{3}\right]$} & \\
\hline 2819.1 & 4421.9 & 80.6 & $8.18 \mathrm{e}-3$ & \multirow{14}{*}{2} \\
\hline 2668.1 & 2819.1 & 80.6 & \multirow{4}{*}{$9.23 e-3$} & \\
\hline 1175.0 & 2668.1 & 80.6 & & \\
\hline 1058.4 & 1175.0 & 80.6 & & \\
\hline 1011.0 & 1058.4 & 80.6 & & \\
\hline 860.0 & 1011.0 & 80.6 & \multirow{5}{*}{$2.83 e-3$} & \\
\hline 653.6 & 860.0 & 80.6 & & \\
\hline 604.8 & 653.6 & 80.6 & & \\
\hline 516.6 & 604.8 & 80.6 & & \\
\hline 457.2 & 516.6 & 80.6 & & \\
\hline-457.2 & 457.2 & 80.6 & $4.67 e-3$ & \\
\hline-516.6 & -457.2 & 80.6 & \multirow{3}{*}{$2.07 e-3$} & \\
\hline-642.6 & -516.6 & 80.6 & & \\
\hline-863.1 & -642.6 & 80.6 & & \\
\hline
\end{tabular}




\section{$\underline{\text { SIDONIE in } 200 \mathrm{~mm} \text { channel }}$}

Table A-12: $200 \mathrm{~mm}$ flow channel with SIDONIE

\begin{tabular}{|c|c|c|c|c|c|c|c|c|}
\hline & & \multicolumn{3}{|c|}{ Silicon crystal } & \multicolumn{4}{|c|}{ Support structure } \\
\hline $\begin{array}{l}\text { Lower } \\
\text { elevation }\end{array}$ & $\begin{array}{l}\text { Upper } \\
\text { elevation }\end{array}$ & Diameter & $\begin{array}{l}\text { Structure } \\
\text { Volume }\end{array}$ & $\begin{array}{c}\text { Material } \\
\#\end{array}$ & $\begin{array}{c}\text { Inner } \\
\text { Diameter }\end{array}$ & Outer Diameter & $\begin{array}{l}\text { Structure } \\
\text { Volume }\end{array}$ & $\begin{array}{c}\text { Material } \\
\#\end{array}$ \\
\hline$[\mathrm{mm}]$ & {$[\mathrm{mm}]$} & {$[\mathrm{mm}]$} & {$\left[\mathrm{m}^{3}\right]$} & & {$[\mathrm{mm}]$} & {$[\mathrm{mm}]$} & {$\left[\mathrm{m}^{3}\right]$} & \\
\hline 2819.2 & 4421.9 & \multirow{22}{*}{127.0} & $2.03 \mathrm{e}-2$ & & & \multirow{22}{*}{$140.9 / 165.0 / 197.5$} & $1.90 \mathrm{e}-2$ & \multirow{22}{*}{2} \\
\hline 2565.3 & 2819.2 & & \multirow{7}{*}{$2.29 \mathrm{e}-2$} & & & & & \\
\hline 2320.8 & 2565.3 & & & & & & & \\
\hline 1981.2 & 2320.8 & & & & & & & \\
\hline 1886.9 & 1981.2 & & & & & & $2.10 \mathrm{e}-2$ & \\
\hline 1075.5 & 1886.9 & & & & & & & \\
\hline 1056.6 & 1075.5 & & & & & & & \\
\hline 1011.0 & 1056.6 & & & & & & & \\
\hline 981.2 & 1011.0 & & & & & & & \\
\hline 943.4 & 981.2 & & & & & & & \\
\hline 861.7 & 943.4 & & & & & & & \\
\hline 732.8 & 861.7 & & $7.02 \mathrm{e}-3$ & 7 or 8 & $134.9 / 150.0 / 175.0$ & & $6.42 \mathrm{e}-3$ & \\
\hline 534.6 & 732.8 & & & & & & & \\
\hline 457.2 & 534.6 & & & & & & & \\
\hline-457.2 & 457.2 & & $1.16 \mathrm{e}-2$ & & & & $1.06 \mathrm{e}-2$ & \\
\hline-534.6 & -457.2 & & \multirow{5}{*}{$5.62 \mathrm{e}-3$} & & & & \multirow{5}{*}{$5.15 \mathrm{e}-3$} & \\
\hline-650.9 & -534.6 & & & & & & & \\
\hline-713.8 & -650.9 & & & & & & & \\
\hline-872.6 & -713.8 & & & & & & & \\
\hline-901.0 & -872.6 & & & & & & & \\
\hline-1056.6 & -901.0 & & \multirow{2}{*}{$1.95 \mathrm{e}-2$} & & & & \multirow{2}{*}{$1.78 \mathrm{e}-2$} & \\
\hline-2438.5 & -1056.6 & & & & & & & \\
\hline
\end{tabular}

Sylcor fuel element assembly in $84 \mathrm{~mm}$ channel

Table A-13: Fuel assembly in $84 \mathrm{~mm}$ channel

\begin{tabular}{|c|c|c|c|c|c|c|c|c|c|c|}
\hline & & \multicolumn{3}{|c|}{ Pin } & \multicolumn{6}{|c|}{ Support tube } \\
\hline $\begin{array}{l}\text { Lower } \\
\text { elevation }\end{array}$ & $\begin{array}{c}\text { Upper } \\
\text { elevation }\end{array}$ & Diameter & $\begin{array}{l}\text { Structure } \\
\text { Volume }\end{array}$ & $\begin{array}{c}\text { Material } \\
\#\end{array}$ & $\begin{array}{c}\text { Inner } \\
\text { Diameter }\end{array}$ & $\begin{array}{c}\text { Outer } \\
\text { Diameter }\end{array}$ & $\begin{array}{l}\text { \# of } \\
\text { Holes }\end{array}$ & $\begin{array}{c}\text { Hole } \\
\text { Diameter }\end{array}$ & $\begin{array}{l}\text { Structure } \\
\text { Volume }\end{array}$ & $\begin{array}{c}\text { Material } \\
\#\end{array}$ \\
\hline$[\mathrm{mm}]$ & {$[\mathrm{mm}]$} & {$[\mathrm{mm}]$} & {$\left[\mathrm{m}^{3}\right]$} & & {$[\mathrm{mm}]$} & {$[\mathrm{mm}]$} & & {$[\mathrm{mm}]$} & {$\left[\mathrm{m}^{3}\right]$} & \\
\hline 4290.9 & 4421.9 & 17.5 & \multirow{2}{*}{$3.86 \mathrm{e}-4$} & \multirow{14}{*}{2} & 22.3 & 38.6 & & & \multirow[b]{2}{*}{$1.25 \mathrm{e}-3$} & \multirow{14}{*}{2} \\
\hline 2819.1 & 4290.9 & 17.5 & & & 22.3 & 38.6 & 4 & 6.35 & & \\
\hline 2668.1 & 2819.1 & 17.5 & \multirow{4}{*}{$4.35 \mathrm{e}-4$} & & 22.3 & 38.6 & & & \multirow{4}{*}{$1.41 \mathrm{e}-3$} & \\
\hline 1165.3 & 2668.1 & 17.5 & & & 22.3 & 38.6 & 6 & 6.35 & & \\
\hline 1058.4 & 1165.3 & 17.5 & & & 22.3 & 38.6 & & & & \\
\hline 1011.0 & 1058.4 & 17.5 & & & 22.3 & 38.6 & & & & \\
\hline 860.0 & 1011.0 & 17.5 & \multirow{8}{*}{$1.33 e-4$} & & 22.3 & 38.6 & & & \multirow{8}{*}{$3.85 \mathrm{e}-4$} & \\
\hline 765.5 & 860.0 & 17.5 & & & 22.3 & 37.2 & & & & \\
\hline 698.5 & 765.5 & 17.5 & & & 22.3 & 37.2 & & & & \\
\hline 672.7 & 698.5 & 17.5 & & & 28.5 & 38.0 & & & & \\
\hline 621.1 & 672.7 & 17.5 & & & 24.0 & 38.0 & & & & \\
\hline 576.4 & 621.1 & 17.5 & & & 20.9 & 38.0 & & & & \\
\hline 508.5 & 576.4 & 17.5 & & & 20.9 & 39.9 & & & & \\
\hline 457.2 & 508.5 & 17.5 & & & 20.9 & 26.1 & & & & \\
\hline-457.2 & 457.2 & 26 & $4.63 e-4$ & 7 or 8 & 0 & 0 & & & 0 & \\
\hline-508.5 & -457.2 & 17.5 & \multirow{3}{*}{$3.94 \mathrm{e}-5$} & \multirow{3}{*}{2} & 20.9 & 26.1 & & & \multirow{6}{*}{$2.01 \mathrm{e}-4$} & \multirow{6}{*}{2} \\
\hline-576.4 & -508.5 & 17.5 & & & 20.9 & 39.9 & & & & \\
\hline-621.1 & -576.4 & 17.5 & & & 20.9 & 38.0 & & & & \\
\hline-672.7 & -621.1 & & & & 24.0 & 38.0 & & & & \\
\hline-698.5 & -672.4 & & & & 28.5 & 38.0 & & & & \\
\hline-765.0 & -698.5 & & & & 22.3 & 37.2 & & & & \\
\hline
\end{tabular}


Sylcor fuel element assembly and 6 irradiation baskets in $200 \mathrm{~mm}$ channel

The fuel element assembly information is not included in this table, it is the same as described above.

Table A-14: $200 \mathrm{~mm}$ flow channel with fuel assembly and 6 irradiation baskets

\begin{tabular}{|c|c|c|c|c|c|c|c|c|c|c|}
\hline & & \multicolumn{3}{|c|}{ Irradiation baskets and support } & \multicolumn{6}{|c|}{ Guide tubes and large Be piece } \\
\hline $\begin{array}{c}\text { Lower } \\
\text { elevation }\end{array}$ & $\begin{array}{c}\text { Upper } \\
\text { elevation }\end{array}$ & $\begin{array}{c}\text { Inner } \\
\text { Diameter }\end{array}$ & $\begin{array}{c}\text { Outer } \\
\text { Diameter }\end{array}$ & Volume & $\begin{array}{c}\text { Inner } \\
\text { Diameter }\end{array}$ & $\begin{array}{c}\text { Outer } \\
\text { Diameter }\end{array}$ & $\begin{array}{l}\text { \# of } \\
\text { Holes }\end{array}$ & $\begin{array}{c}\text { Hole } \\
\text { Diameter }\end{array}$ & $\begin{array}{l}\text { Structure } \\
\text { Volume }\end{array}$ & $\begin{array}{c}\text { Material } \\
\#\end{array}$ \\
\hline$[\mathrm{mm}]$ & {$[\mathrm{mm}]$} & {$[\mathrm{mm}]$} & {$[\mathrm{mm}]$} & {$\left[\mathrm{m}^{3}\right]$} & {$[\mathrm{mm}]$} & {$[\mathrm{mm}]$} & & {$[\mathrm{mm}]$} & {$\left[\mathrm{m}^{3}\right]$} & \\
\hline 2819.2 & 4421.9 & 15.9 & 25.4 & $2.97 \mathrm{e}-3$ & 85.6 & 88.9 & 468 & 6.35 & $4.32 \mathrm{e}-3$ & \multirow{14}{*}{2} \\
\hline 2565.3 & 2819.2 & 15.9 & 25.4 & \multirow{7}{*}{$3.35 e-3$} & 85.6 & 88.9 & 66 & 6.35 & \multirow{7}{*}{$4.90 \mathrm{e}-3$} & \\
\hline 2320.8 & 2565.3 & 15.9 & 25.4 & & 85.6 & 88.9 & 66 & 6.35 & & \\
\hline 1981.2 & 2320.8 & 15.9 & 25.4 & & 85.6 & 88.9 & & & & \\
\hline 1886.9 & 1981.2 & 15.9 & 25.4 & & 85.6 & 88.9 & & & & \\
\hline 1075.5 & 1886.9 & 15.9 & 25.4 & & 85.6 & 88.9 & & & & \\
\hline 1056.6 & 1075.5 & 15.9 & 25.4 & & 85.6 & 88.9 & & & & \\
\hline 1011.0 & 1056.6 & 15.9 & 25.4 & & 85.6 & 88.9 & & & & \\
\hline 981.2 & 1011.0 & 15.9 & 25.4 & \multirow{6}{*}{$1.33 e-3$} & 85.6 & 88.9 & & & \multirow{6}{*}{$7.99 e-3$} & \\
\hline 943.4 & 981.2 & 15.9 & 25.4 & & 85.6 & 88.9 & & & & \\
\hline 861.7 & 943.4 & 15.9 & 25.4 & & 85.6 & 88.9 & & & & \\
\hline 732.8 & 861.7 & 15.9 & 25.4 & & 85.6 & 88.9 & & & & \\
\hline 534.6 & 732.8 & 0 & 25 & & 81.6 & 200.2 & & & & \\
\hline 457.2 & 534.6 & 0 & 25 & & 81.6 & 200.2 & & & & \\
\hline-457.2 & 457.2 & 0 & 25 & $2.69 \mathrm{e}-3$ & 81.6 & 200.2 & & & $2.40 \mathrm{e}-2$ & 7 or 8 \\
\hline-534.6 & -457.2 & 0 & 25 & \multirow{2}{*}{$5.71 \mathrm{e}-4$} & 81.6 & 200.2 & & & \multirow{3}{*}{$6.74 \mathrm{e}-3$} & \multirow{3}{*}{2} \\
\hline-650.9 & -534.6 & 0 & 25 & & 81.6 & 200.2 & & & & \\
\hline-713.8 & -650.9 & & & & 81.6 & 200.2 & & & & \\
\hline
\end{tabular}




\section{Sylcor fuel element}

Table A-15: Sylcor fuel element used in the 1963 experiments.

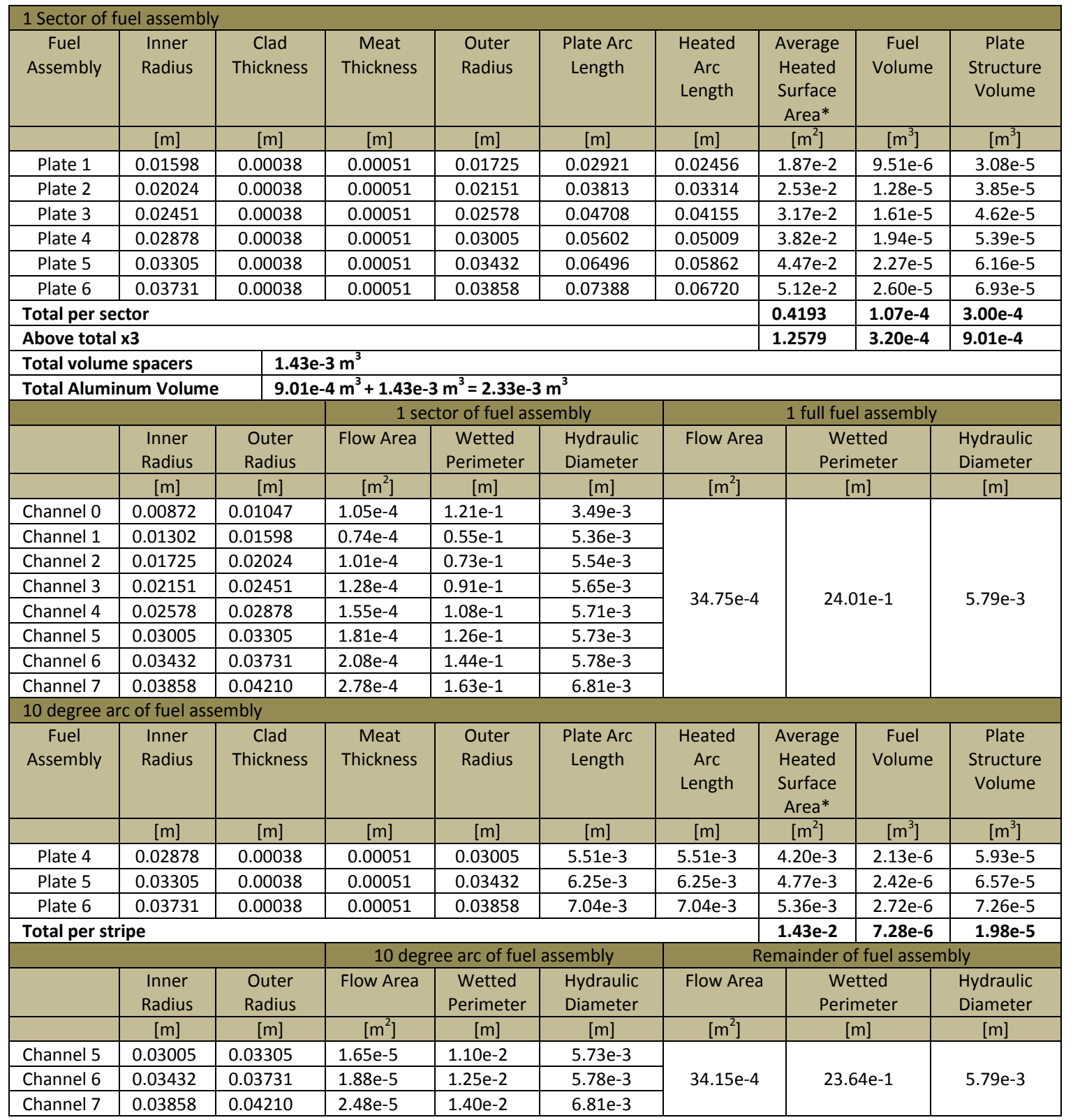

* This value is only half of the total heated area of a fuel plate. 


\section{A.6 RELAP5 channel heat structures (1963 core)}

\section{A.6.1 Average fuel channel}

The 1963 BR2 core contained 13 channels consolidated into a single average fuel channel. Table A-16 shows the description for each of the structure associated with this channel. The thermal connections were based on the actual length or surface area of the component times the 13 channels to properly account for the heat transfer and thermal mass. Below is a brief description of each of the structures associated with this channel.

\section{$\underline{\text { Heat structure } 500}$}

Represents the section of channel above the core for the average fuel channel. Its radial dimensions were based on the $84 \mathrm{~mm}$ channel. Because the channel extends above the reactor vessel, it's partially in contact with the volume describing the reactor pool. Below this, the channel was thermally connected to the respective bypass coolant volumes. The channel was assumed to be stainless steel 304L.

\section{Heat structure 501}

Represents the channels internal components (not including the fuel) that extend from coolant volume 50 to 58 . This structure was modeled as a cylinder and it was assumed that the entire component was aluminum.

\section{Heat structure 560}

Represents the beryllium channel within the core region. It was internally connected to volume 56 and externally to volume 16 .

\section{Heat structure 561}

Represents the average fuel element. It was modeled as a plate geometry that connects to coolant volume 56 at both its left and right boundary. The surface area is representative of the total surface area of 13 fuel elements but its radial dimensions are that of a single plate. The plate is composed of cladding material (AG3NE) and fresh HEU fuel. The plate dimensions include a cladding thickness of $0.38 \mathrm{~mm}$ and a fuel meat thickness of $0.51 \mathrm{~mm}$. This structure only contains the aluminum cladding radially separating the fuel from the coolant. The remainder of the aluminum was attributed to heat structure 501

\section{Heat structure 580}

This structure is similar to heat structure 500 except that it represents the section of channel below the core region. 
Table A-16 Heat structure for average channel with fuel element

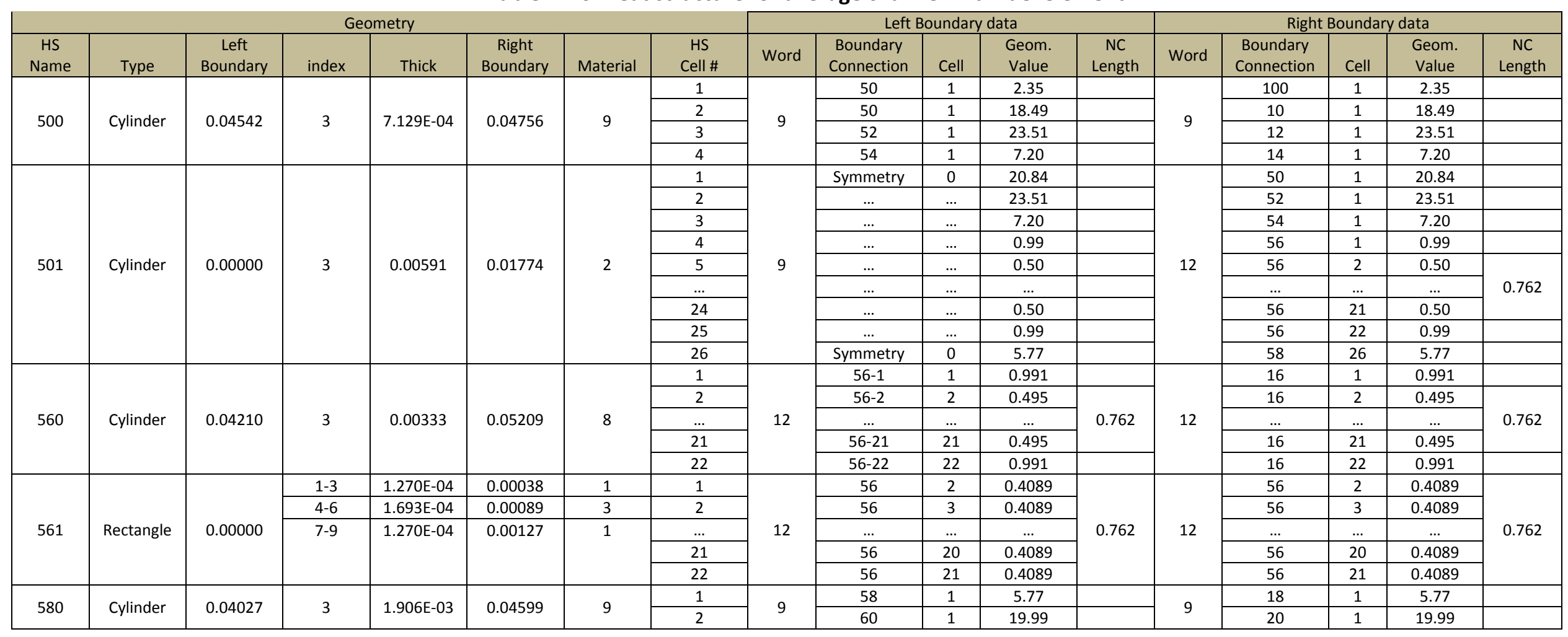




\section{A.6.2 High heat flux fuel channel}

The heat structures of the high heat flux channel are similar to the average fuel channel except for the core region where the fuel element has been discretized into four structures (Table A-17). Three of these are a 10 degree arc representing the axial high heat flux stripe of the outer three fuel element plates. The fourth is the remainder of the fuel in this channel.

Heat structures 300,301 and 380

Same as described for the average fuel channel except that the surface area and length of the thermal connections were based on a single channel.

\section{Heat structure 360}

Represents the portion of the fuel element in the high heat flux channel that is not associated with the hot stripes. This was modeled as a plate geometry similar to that of heat structure 561 . Its surface area was based on that of the fuel element minus the hot stripe structures.

Heat structure 364,365 and 366

Represents the hot stripes associated with fuel element plates 4, 5 and 6 . The structures were thermally connected to neighboring coolant volumes where the left connection was considered inward and the right connection considered outward. The left side of plate 4 was connected to the coolant volume associated with the remainder of the channel.

\section{$\underline{\text { Heat structure } 367}$}

Represents the 10 degree arc of the beryllium channel in the core region. Because of the small angle, this structure was modeled as a plate geometry connected to volume 367 at its left side and to volume 16 at its right side.

\section{$\underline{\text { Heat structure } 368}$}

Represents the remainder of the beryllium channel within the core region. The structure was modeled as cylindrical geometry with the proper inner diameter and a slightly reduced outer diameter (relative to structure 560) to compensate from the volume of beryllium in heat structure 367. 
Table A-17: Channel with high heat flux fuel element.

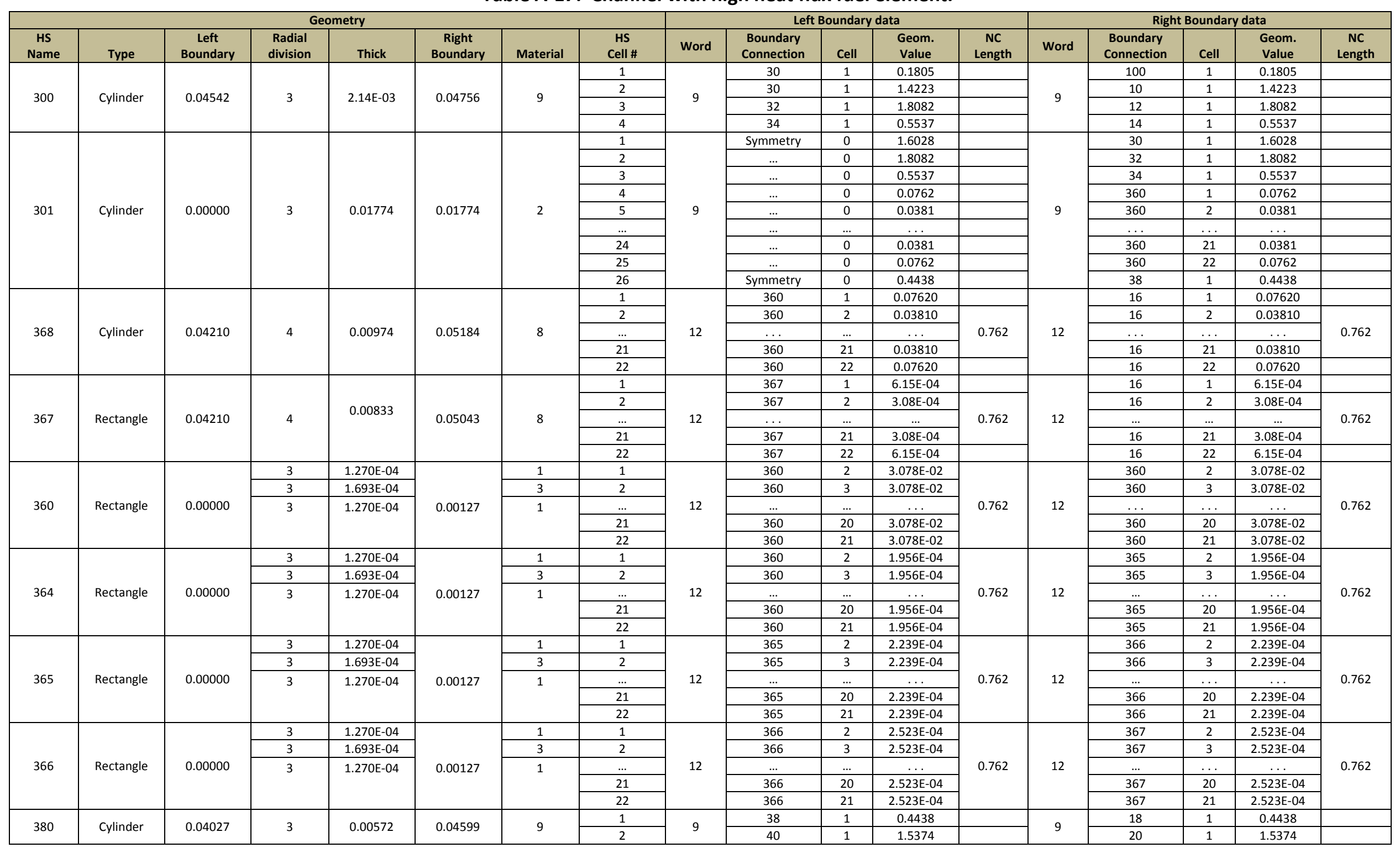




\section{A.6.3 Plugged channel}

The structure describing the plugged channel is similar to the average fuel channel except that the core contains a cylinder representative of the plug material instead of fuel plates (Table A-18).

Heat structure 700,701 and 780

Same as described for the average fuel channel except that the surface area and length of the thermal connections were based on the consolidation of the 65 channels attributed to the plugged channel.

$\underline{\text { Heat structure } 702}$

Represents the "plugs" within the fuelled region. This was modeled as a cylinder thermally connected to coolant volume 76 .

$\underline{\text { Heat structure } 760}$

Represents the beryllium channel within the core region and is similar to heat structure 560 . 
Table A-18: heat structure describing plugged channel.

\begin{tabular}{|c|c|c|c|c|c|c|c|c|c|c|c|c|c|c|c|c|c|}
\hline \multicolumn{8}{|c|}{ Geometry } & \multicolumn{5}{|c|}{ Left Boundary data } & \multicolumn{5}{|c|}{ Right Boundary data } \\
\hline $\begin{array}{l}\text { HS } \\
\text { Name }\end{array}$ & Type & $\begin{array}{c}\text { Left } \\
\text { Boundary }\end{array}$ & index & Thick & $\begin{array}{c}\text { Right } \\
\text { Boundary }\end{array}$ & Material & $\begin{array}{l}\text { HS } \\
\text { Cell \# }\end{array}$ & Word & $\begin{array}{l}\text { Boundary } \\
\text { Connection }\end{array}$ & Cell & $\begin{array}{l}\text { Geom. } \\
\text { Value }\end{array}$ & $\begin{array}{c}\text { NC } \\
\text { Length }\end{array}$ & Word & $\begin{array}{l}\text { Boundary } \\
\text { Connection }\end{array}$ & Cell & $\begin{array}{l}\text { Geom. } \\
\text { Value }\end{array}$ & $\begin{array}{c}\text { NC } \\
\text { Length }\end{array}$ \\
\hline \multirow{4}{*}{700} & \multirow{4}{*}{ Cylinder } & \multirow{4}{*}{0.05018} & \multirow{4}{*}{3} & \multirow{4}{*}{$1.076 \mathrm{E}-03$} & \multirow{4}{*}{0.05340} & \multirow{4}{*}{9} & 1 & \multirow{4}{*}{9} & 70 & 1 & 11.73 & & \multirow{4}{*}{9} & 100 & 1 & 11.73 & \\
\hline & & & & & & & 2 & & 70 & 1 & 92.45 & & & 10 & 1 & 92.45 & \\
\hline & & & & & & & 3 & & 72 & 1 & 117.53 & & & 12 & 1 & 117.53 & \\
\hline & & & & & & & 4 & & 74 & 1 & 35.99 & & & 14 & 1 & 35.99 & \\
\hline \multirow{8}{*}{701} & \multirow{8}{*}{ Cylinder } & \multirow{8}{*}{0.00000} & \multirow{8}{*}{3} & \multirow{8}{*}{$7.181 \mathrm{E}-03$} & \multirow{8}{*}{0.02154} & \multirow{8}{*}{2} & 1 & \multirow{8}{*}{9} & Symmetry & 0 & 104.18 & & \multirow{8}{*}{9} & 70 & 1 & 104.18 & \\
\hline & & & & & & & 2 & & $\ldots$ & $\ldots$ & 117.53 & & & 72 & 1 & 117.53 & \\
\hline & & & & & & & 3 & & $\ldots$ & $\ldots$ & 35.99 & & & 74 & 1 & 35.99 & \\
\hline & & & & & & & 5 & & $\ldots$ & $\ldots$ & 2.477 & & & $76-2$ & 2 & 2.477 & \\
\hline & & & & & & & $\ldots$ & & $\ldots$ & $\ldots$ & $\ldots$ & & & $\ldots$ & $\ldots$ & $\ldots$ & \\
\hline & & & & & & & 24 & & $\ldots$ & $\ldots$ & 2.477 & & & $76-21$ & 21 & 2.477 & \\
\hline & & & & & & & 25 & & $\ldots$ & $\ldots$ & 4.953 & & & $76-22$ & 22 & 4.953 & \\
\hline & & & & & & & 26 & & Symmetry & 0 & 28.85 & & & 78 & 1 & 28.85 & \\
\hline \multirow{4}{*}{702} & \multirow{4}{*}{ Cylinder } & \multirow{4}{*}{0.00000} & \multirow{4}{*}{3} & \multirow{4}{*}{$1.430 \mathrm{E}-02$} & \multirow{4}{*}{0.04291} & & 1 & & Symmetry & 0 & 4.953 & & & 76-1 & 1 & 4.953 & \\
\hline & & & & & & & 2 & & $\ldots$ & $\ldots$ & 2.477 & & & $76-2$ & 2 & 2.477 & \\
\hline & & & & & & 8 & $\ldots$ & 12 & $\ldots$ & $\ldots$ & $\ldots$ & 0.762 & 12 & $\ldots$ & $\ldots$ & $\ldots$ & 0.762 \\
\hline & & & & & & & 21 & & $\ldots$ & $\ldots$ & 2.477 & & & $76-21$ & 21 & 2.477 & \\
\hline & & & 3 & $4.488 \mathrm{E}-03$ & 0.06097 & 8 & 1 & & $76-1$ & 1 & 4.953 & & & $16-1$ & 1 & 4.953 & \\
\hline & & & $4-6$ & $1.693 \mathrm{E}-04$ & 0.00089 & 3 & 2 & & $76-2$ & 2 & 2.477 & & & $16-2$ & 2 & 2.477 & \\
\hline 760 & Cylinder & 0.04751 & $7-9$ & $1.270 \mathrm{E}-04$ & 0.00127 & 1 & $\ldots$ & 12 & $\ldots$ & $\ldots$ & $\ldots$ & 0.762 & 12 & $\ldots$ & $\ldots$ & $\ldots$ & 0.762 \\
\hline & & & & & & & 21 & & $76-21$ & 21 & 2.477 & & & $16-21$ & 21 & 2.477 & \\
\hline & & & & & & & 22 & & $76-22$ & 22 & 4.953 & & & $16-22$ & 22 & 4.953 & \\
\hline & & & & & & & 1 & 9 & 78 & 1 & 28.85 & & 9 & 18 & 1 & 28.85 & \\
\hline 780 & Cylinder & 0.04617 & 3 & $2.123 \mathrm{E}-03$ & 0.05254 & 9 & 2 & & 80 & 1 & 99.93 & & & 20 & 2 & 99.93 & \\
\hline
\end{tabular}




\section{B Hydraulic Volumes and Junctions}

Data for the hydraulic volumes and there junctions are given in the tables within this section. The data in these tables have been acquired from legacy documents/notes and RELAP5 input files provided by the BR2 team. The following sections summarize this information. It should be noted that the loss coefficients described in this appendix do not include the changes made due to the calibration process. Loss coefficients were determined using the correlations given in reference [16].

\section{B.1 Bypass channel}

The bypass channel represents all coolant volumes within the reactor vessel except for the volumes within the $50 \mathrm{~mm}, 84 \mathrm{~mm}$ and $200 \mathrm{~mm}$ channels. The following is a description of each coolant volume in the bypass channel.

\section{Volume 8}

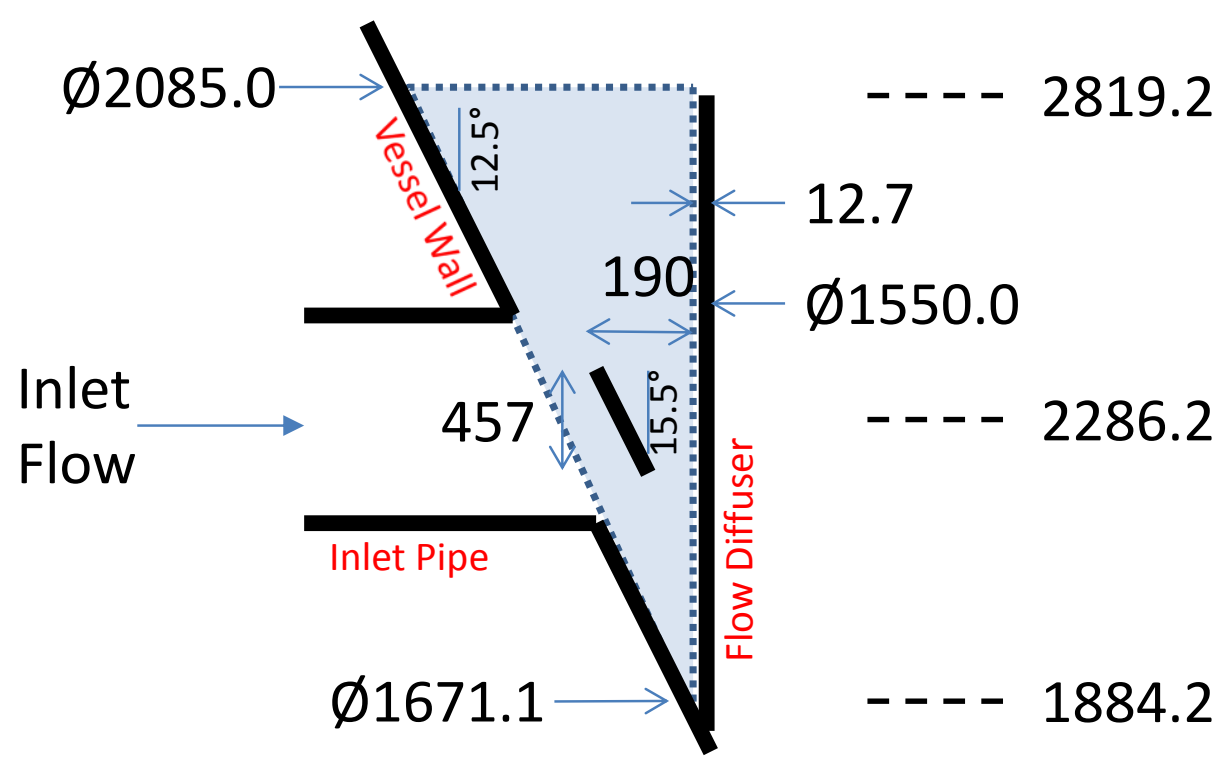

Figure B-1 Sketch of RELAP5 volume 8. Dimensions in $\mathbf{m m}$.

This volume represents the annular entrance region between the inner flow diffuser and the reactor vessel and inlet piping. Reference for the information of this component was made to document \#47108. The volume $\left(0.771 \mathrm{~m}^{3}\right)$ was based on the total conical volume of the vessel section $\left(2.6 \mathrm{~m}^{3}\right)$ minus the region occupied by the flow diffuser $\left(1.82 \mathrm{~m}^{3}\right)$, the four deflector plates $\left(0.0029 \mathrm{~m}^{3}\right)$, and other miscellaneous structures $\left(0.0057 \mathrm{~m}^{3}\right)$. The physical elevation change of volume 8 is $0.935 \mathrm{~m}$ $(2.8192 \mathrm{~m}-1.8842 \mathrm{~m})$. However, the inlet piping connects to volume 8 with the RELAP5 cross flow model which requires a mid-cell connection. The RELAP5 volume length was modified to be $1.066 \mathrm{~m}$ to match its cross flow elevation to the inlet piping elevation $(2.2862 \mathrm{~m})^{8}$. Utilizing the calculated volume and modified length, the cross flow area was calculated to be $0.723 \mathrm{~m}^{2}$. The hydraulic diameter was calculated to be $0.303 \mathrm{~m}$ based on the difference between the reactor vessel and flow diffuser diameter (1.878 $\mathrm{m}$ and $1.575 \mathrm{~m})$ at the midpoint elevation of $2.3517 \mathrm{~m}(2.8192 \mathrm{~m}-0.935 \mathrm{~m} / 2)$.

${ }^{8} 2.8192 \mathrm{~m}-2.2862 \mathrm{~m}=0.533 \mathrm{~m} ; 0.533 \mathrm{~m} \times 2=1.066 \mathrm{~m}$. 
The hydraulic junction between volume 8 and 10 is integral to volume 8 . The hydraulic diameter and flow rate were based on the values calculated for volume 8 and the flow resistance was calculated with the abrupt area change model within RELAP5. The inlet pipe was connected to this branch utilizing a cross flow junction.

Volume 10

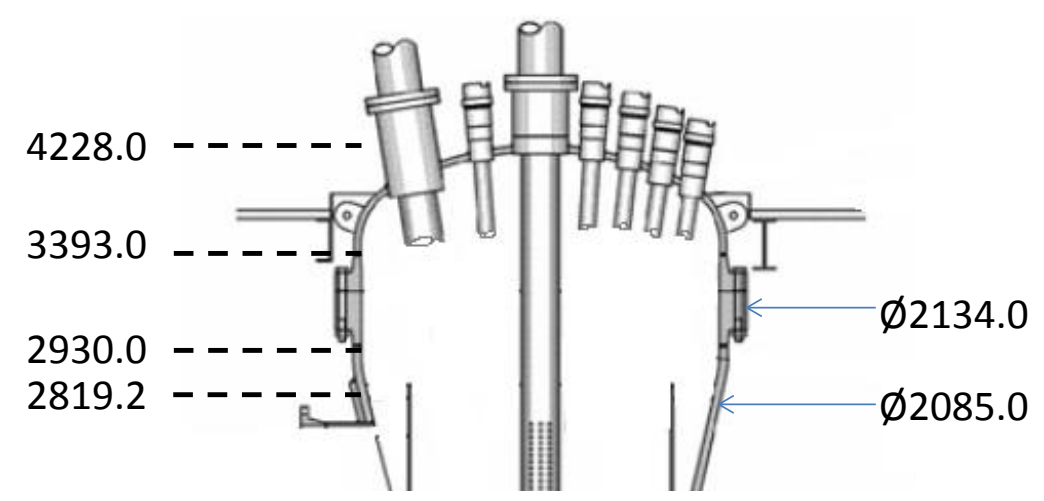

Figure B-2 Sketch of RELAP5 volume 10. Dimensions in mm.

This volume represents the upper region of the reactor vessel. The elevation for this volume was specified as $2.8192 \mathrm{~m}$ to $4.2280 \mathrm{~m}$. Its interior volume includes the upper vessel cover $\left(2.34 \mathrm{~m}^{3}\right)$, the cylindrical body $\left(1.66 \mathrm{~m}^{3}\right)$ and upper part of the conical vessel above the reactor core $\left(0.38 \mathrm{~m}^{3}\right)$. The total volume, minus the internal structures $\left(-0.051 \mathrm{~m}^{3}-0.736 \mathrm{~m}^{3}-0.294 \mathrm{~m}^{3}\right)$, was calculated to be $3.3 \mathrm{~m}^{3}$. ). The hydraulic diameter $\left(4 * 2.34 \mathrm{~m}^{2} / 30.72 \mathrm{~m}=0.3047 \mathrm{~m}\right)$ was determined from the flow area and wetted perimeter. The cross section area was calculated by dividing the volume by the length $\left(2.34 \mathrm{~m}^{2}\right)$. The wetted perimeter was calculated from the surface of the structures divided by their lengths.

$\underline{\text { Junction between Volume } 10 \text { and } 12}$

This junction was integral to volume 12 . The hydraulic diameter and flow area were based on that calculated for volume 10. No flow loss coefficients were included in this junction due to the relatively small pressure drop associated with it. 
Volume 12

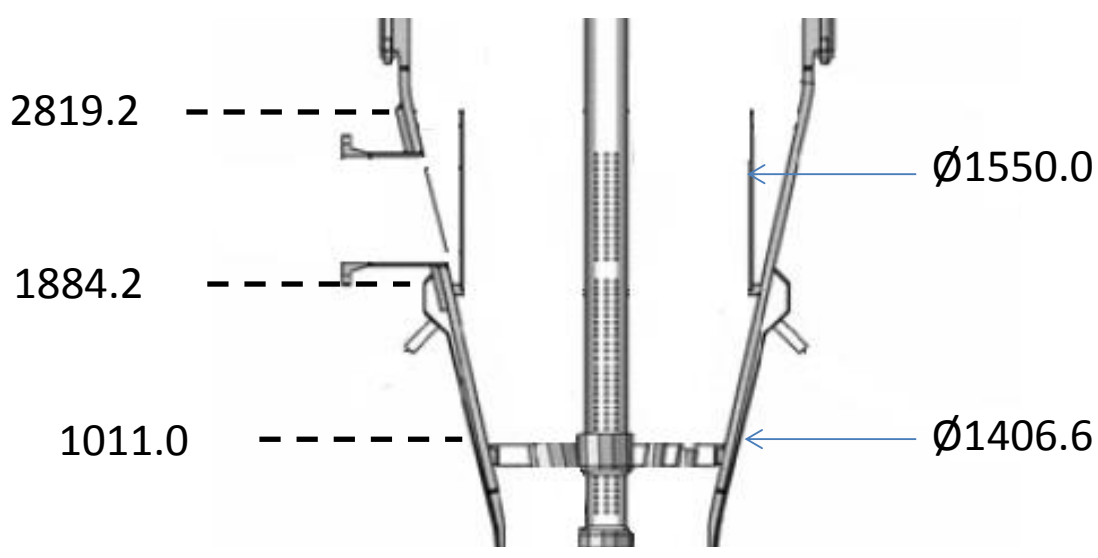

Figure B-3 Sketch of RELAP5 volume 12. Dimensions in mm.

Volume 12 represents the volume inside the flow diffuser $\left(1.764 \mathrm{~m}^{3}\right)$ and a portion of the conical vessel above the core region $\left(1.5 \mathrm{~m}^{3}\right)$. The elevation was specified as $1.011 \mathrm{~m}$ to $2.8192 \mathrm{~m}$. The total volume excluding internal structure $\left(1.28 \mathrm{~m}^{3}\right)$ was calculated to be $1.98 \mathrm{~m}^{3}$. From this, the flow area was calculated to be $1.096 \mathrm{~m}^{2}\left(1.98 \mathrm{~m}^{3} /[2.819 \mathrm{~m}-1.011 \mathrm{~m}]\right)$. The hydraulic diameter was calculated to be $0.148 \mathrm{~m}$ and was calculated from the cross sectional flow area and wetted perimeter. The wetted perimeter for the vessel and the channels was calculated from their surface area divided by their length.

Junction between Volume 12 and 14

The hydraulic connection between volumes 12 and 14 was modeled as integral to volume 14 . The cross sectional area was determined by subtracting the area of the three channel sizes from the area of the reactor vessel $\left(0.140 \mathrm{~m}^{2}\right)$. BR2 notes indicate this area was taken at a specific elevation where the inner radius of the vessel was $0.58235 \mathrm{~m}$. Utilizing the loss coefficient equation for thick edged orifices:

$$
k=0.5\left(1-\frac{F 0}{F 1}\right)+\left(1-\frac{F 0}{F 2}\right) ; \quad \frac{F 0}{F 1}=\frac{0.140}{1.095} ; \quad \frac{F 0}{F 2}=\frac{0.140}{0.358}
$$

the forward loss coefficient was found to be 0.82 and the reverse loss coefficient was found to be 1.07. The hydraulic diameter of this junction was calculated from the flow area and wetted perimeter of the vessel and three channel sizes $\left(4 * 0.140 \mathrm{~m}^{2} /[3.66+2.85+20.17+4.76]=0.0178 \mathrm{~m}\right)$.

\section{$\underline{\text { Volume } 14}$}

Volume 14 is the region between the upper matrix support and the core region. Its elevation was specified as $0.4572 \mathrm{~m}$ to $1.011 \mathrm{~m}$. The volume was determined by subtracting the volume occupied by the 79 channels and heat structure 140 from the volume bounded by the vessel $\left(0.607 \mathrm{~m}^{3}-0.409 \mathrm{~m}^{3}\right.$ $\left.0.0078 \mathrm{~m}^{3}=0.190 \mathrm{~m}^{3}\right)$. The cross sectional area was calculated from the volume divided by the length $\left(0.190 \mathrm{~m}^{3} / 0.554 \mathrm{~m}=0.343 \mathrm{~m}^{2}\right)$ and the hydraulic diameter was calculated from the cross sectional flow area and wetted perimeter $\left(4 * 0.343 \mathrm{~m}^{2} /[3.66 \mathrm{~m}+2.21 \mathrm{~m}+18.8 \mathrm{~m}+3.9 \mathrm{~m}]=0.048\right)$. 
Junction between volumes 14 and 16

The hydraulic junction between volumes 14 and 16 was modeled with the hydraulic diameter and flow area calculated for volume 16 (based on representing the junction by the volume with the smallest flow area). Utilizing the loss coefficient equation for sudden contraction:

$$
k_{\text {forward }}=0.5\left(1-\frac{F 0}{F 1}\right) ; \quad k_{\text {reverse }}=\left(1-\frac{F 0}{F 1}\right)^{2} ; \quad \frac{F 0}{F 1}=\frac{0.0386}{0.343}
$$

the forward and reverse loss coefficients were calculated to be 0.45 and 0.80 , respectively.

\section{$\underline{\text { Volume } 16}$}

Volume 16 represents the core bypass. The elevation for this volume was specified as $-0.4572 \mathrm{~m}$ to $0.4572 \mathrm{~m}$. Its hydraulic diameter was calculated from the difference in vessel and matrix diameter $(1.1070 \mathrm{~m}-1.0999 \mathrm{~m}=0.0071 \mathrm{~m})$ at the core mid-plane. The cross-sectional flow area was determined from its volume divided by its length $\left(0.0353 \mathrm{~m}^{3} / 0.9144 \mathrm{~m}=0.0386 \mathrm{~m}^{2}\right)$. Here, the volume consisted of three components:

1. The space between the vessel and the matrix $\left(0.0127 \mathrm{~m}^{3}\right)$,

2. 24 cooling holes of $15.2 \mathrm{~mm}$ diameter within the beryllium matrix $\left(0.0126 \mathrm{~m}^{3}\right)$, and

3. Spacing between the channels $\left(0.01 \mathrm{~m}^{3}\right)^{9}$.

$\underline{\text { Junction between volumes } 16 \text { and } 18}$

The hydraulic junction between volumes 16 and 18 was modeled with the hydraulic diameter and flow area calculated for volume 16 . Utilizing the loss coefficient equation for sudden expansion:

$$
k_{\text {forward }}=\left(1-\frac{F 0}{F 1}\right)^{2} ; \quad k_{\text {reverse }}=0.5\left(1-\frac{F 0}{F 1}\right) ; \quad \frac{F 0}{F 1}=\frac{0.0386}{0.417}
$$

the forward and reverse loss coefficients were calculated to be 0.82 and 0.45 , respectively.

$\underline{\text { Volume } 18}$

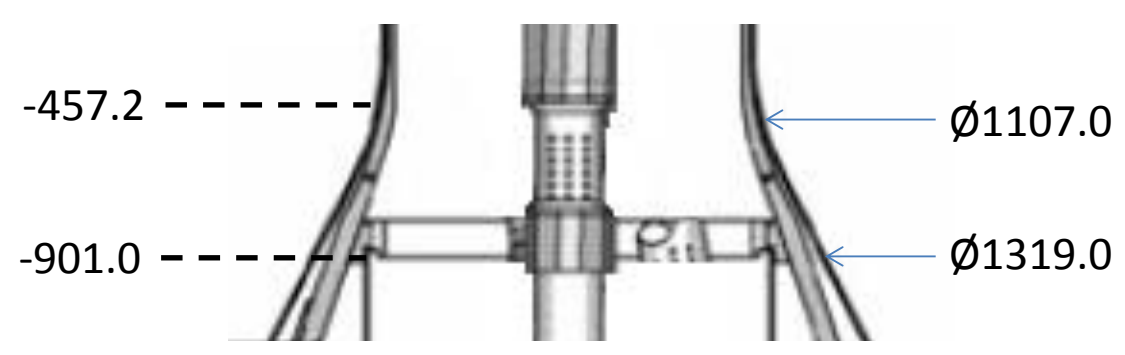

Figure B-4 Sketch of RELAP5 volume 18. Dimensions in $\mathrm{mm}$.

Volume 18 is the region immediately below the core. Its elevation was specified as $-0.901 \mathrm{~m}$ to $-0.4572 \mathrm{~m}$. Relative to the vessel, it is located at the intersection of the cylindrical section of vessel in

${ }^{9}$ This was based on a nominal spacing of $0.4 \mathrm{~mm}$ between each of the channels. 
the core region and the conical section beneath it. Thus, its internal volume was the sum of volume within these regions minus the internal structures $\left(0.127 \mathrm{~m}^{3}+0.361 \mathrm{~m}^{3}-0.303 \mathrm{~m}^{3}=0.185 \mathrm{~m}^{3}\right)$. The flow area was found from dividing the volume by its height $\left(0.185 \mathrm{~m}^{3} / 0.4438 \mathrm{~m}=0.4169 \mathrm{~m}^{2}\right)$. The hydraulic diameter was calculated to be 0.059 based on the flow area and wetted perimeter. The wetted perimeter of the vessel was based on the surface area divided by the height.

Junction between volumes 18 and 20

The hydraulic connection between volume 18 and volume 20 is integral to volume 20. A flow area of $0.144 \mathrm{~m}^{2}$ was calculated by taking the difference between the vessel area and three flow channel size areas $\left(p^{*} 1.166 m^{\wedge} 2 / 4-0.5 m^{2}-0.064 m^{2}-0.36 m^{2}\right)$. The hydraulic diameter was calculated to be $0.018 m$. Utilizing the loss coefficient equation for thick edged orifices:

$$
k=0.5\left(1-\frac{F 0}{F 1}\right)+\left(1-\frac{F 0}{F 2}\right) ; \quad \frac{F 0}{F 1}=\frac{0.144}{0.417} ; \quad \frac{F 0}{F 2}=\frac{0.144}{0.660}
$$

the forward and reverse loss coefficients were calculated to be 0.9 and 0.82 , respectively.

Volume 20

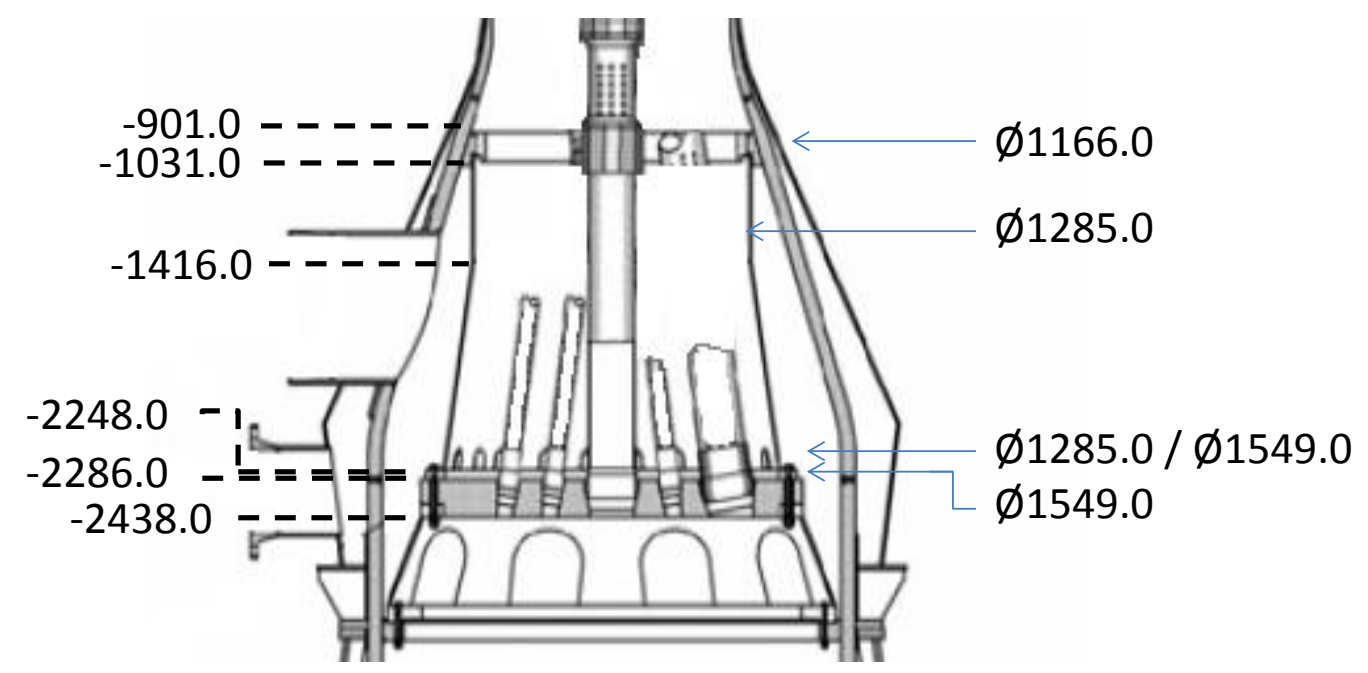

Figure B-5 Sketch of RELAP5 volume 20. Dimensions in $\mathbf{m m}$.

Volume 20 is located between the outlet flow guide flow channels and its elevation was specified as $-2.4384 \mathrm{~m}$ to $-0.901 \mathrm{~m}$. The total volume was constructed from 4 regions; two upper cylindrical sections, a conical section and a lower region where the flow channels mate with the support grid. After subtraction of the flow channel volumes the resulting volume was found to be $1.015 \mathrm{~m}^{3}\left(2.026 \mathrm{~m}^{3}-\right.$ $\left.1.011 \mathrm{~m}^{3}\right)$. Utilizing the volume height of $1.537 \mathrm{~m}$, the cross section flow area was found to be $0.660 \mathrm{~m}^{2}$. A hydraulic diameter of $0.095 \mathrm{~m}$ was based on the flow area and the total wetted perimeter of the flow guide and flow channels.

Junction between volumes 20 and 24 
The hydraulic connection between volumes 20 and 24 consists of 24 holes represented by a junction integral to Volume 20. The total cross-sectional area of the junction was calculated to be $0.146 \mathrm{~m}^{2}$. The total wetted perimeter was calculated to be $7.10 \mathrm{~m}$. The hydraulic diameter was specified as $0.095 \mathrm{~m}$. The forward and reverse flow loss coefficients were calculated by using the lookup tables for a sharp edged orifice:

Forward F0/F1 $=0.146 / 0.660=0.22, F 0 / F 2=0.146 / 1.067=0.136: \mathrm{k}=2.22$

Reverse FO/F1 $=0.146 / 1.067=0.136, F 0 / F 2=0.146 / 0.660=0.22: k=2.07$

\section{Volume 22}

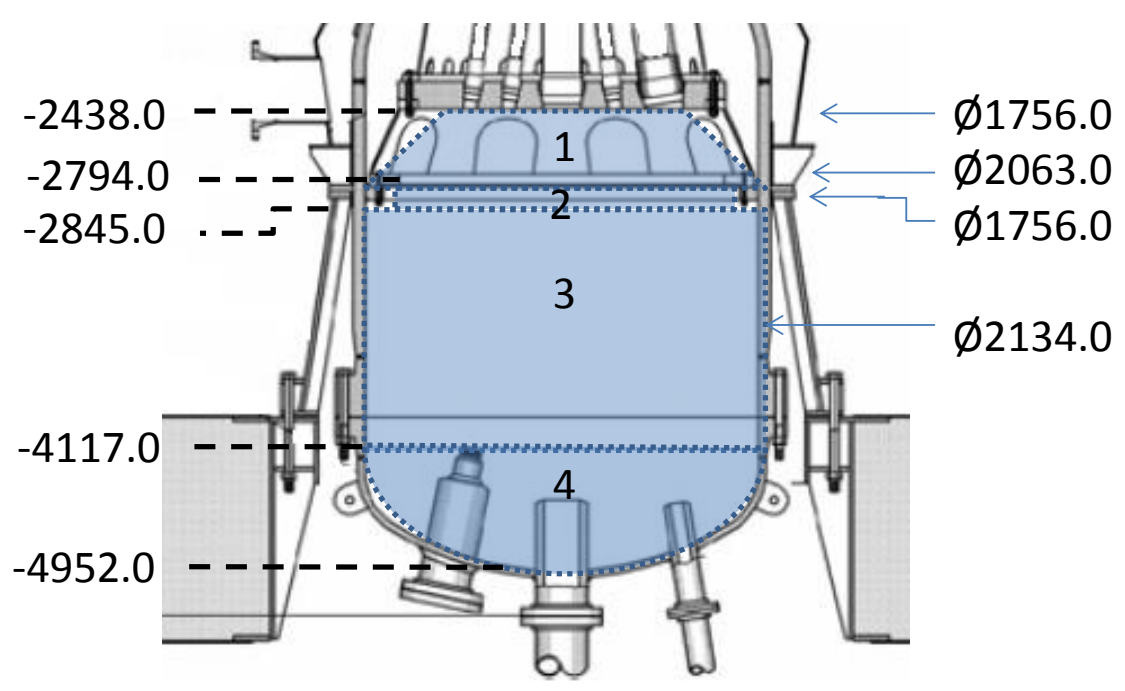

Figure B-6 Sketch of RELAP5 volume 22. Dimensions in $\mathbf{m m}$.

The flow from the fuel channels discharges into Volume 22 located at the bottom of the reactor vessel and has been included in the bypass flow channel since its model does not change with core configuration. Its elevation was specified as $-4.9519 \mathrm{~m}$ to $-2.4384 \mathrm{~m}$. The total volume was calculated to be $8.0 \mathrm{~m}^{3}$ based on four distinct volumes consisting of a conical region just below the support plate, a thin cylindrical section of relatively small diameter, the main cylindrical body and the lower vessel cover. The cross sectional flow area was based on the volume divided by its height $\left(8 \mathrm{~m}^{3} / 2.5235 \mathrm{~m}=3.183 \mathrm{~m}^{2}\right)$. Calculations were not found for the hydraulic diameter but the specified value of $2.01 \mathrm{~m}$ seems to be reasonable value based on the diameters of the components.

Junction between volumes 22 and 24

The hydraulic connection between volumes 22 and 24 consists of 10 holes represented by a junction integral to Volume 24 . The total cross-sectional area of the junction was specified as $1.138 \mathrm{~m}^{2}$. The hydraulic diameter was calculated as $4 * \mathrm{Pw} / \mathrm{Dh}=4 * 1.138 /(0.18 * 2+.345+\mathrm{pi} * 0.1815)=0.357 \mathrm{~m}$. The forward and reverse flow loss coefficients were calculated by using the lookup tables for a sharp edged orifice:

Forward F0/F1 $=1.138 / 3.183=0.358, \mathrm{~F} 0 / \mathrm{F} 2=1.138 / 1.067=\sim 1: \mathrm{k}=0.33$ 


\section{Volume 24}

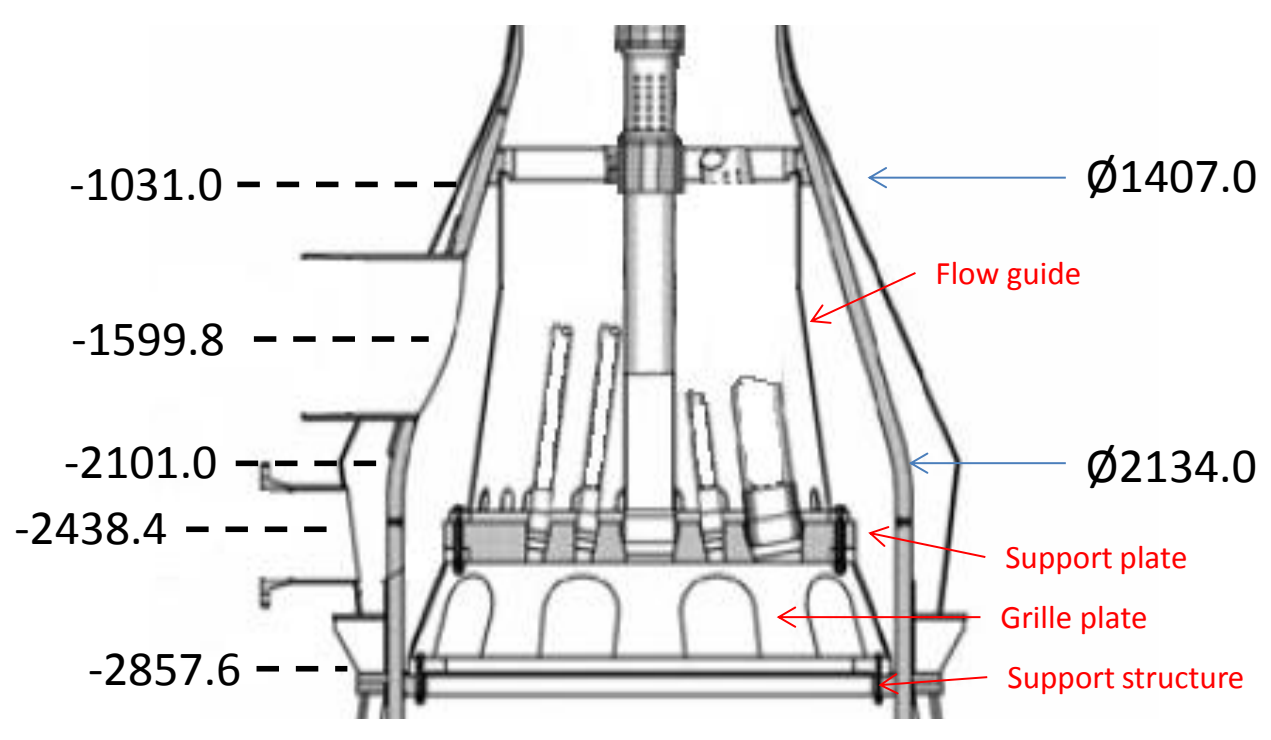

Figure B-7 Sketch of RELAP5 volume 24. Dimensions in $\mathbf{m m}$.

Volume 24 represents the volume of fluid between the reactor vessel and the outlet flow guide. The elevation was specified as $-2.8576 \mathrm{~m}$ to $-0.9010 \mathrm{~m}$. The geometry of this volume in RELAP5 was modeled based on the constraints of its junctions to volume 22 and the exit piping. The cross flow model was used to connect the outlet piping to volume 24 . Since this was modeled as a branch, its crossflow connection to the outlet piping required that the branch mid plane be equivalent to the elevation of the outlet piping. The length of the branch $(1.677 \mathrm{~m})$ was chosen so that its inlet connection was at the same elevation as the outlet elevation of volume 20 . The cross sectional flow area $\left(1.07 \mathrm{~m}^{2}\right)$ was determined by dividing the coolant volume $\left(1.784 \mathrm{~m}^{3}\right)$ by its length $(1.677 \mathrm{~m})$. The coolant volume was determined by calculating the volume in the vessel $\left(5.37 \mathrm{~m}^{3}\right)$ and subtracting from this the internal structures/coolant (flow guide $1.94 \mathrm{~m}^{3}$, channel support plate $0.252 \mathrm{~m}^{3}$, grille plate $1.344 \mathrm{~m}^{3}$ and support structure $0.0454 \mathrm{~m}^{3}$ ). 
Table B-1 Description of coolant volume for the bypass channel

\begin{tabular}{|c|c|c|c|c|c|c|c|c|c|}
\hline $\begin{array}{c}\text { RELAP5 } \\
\#\end{array}$ & Type & Node & $\begin{array}{l}\text { Actual } \\
\text { Length }\end{array}$ & Flow Area & Volume & $\begin{array}{l}\text { Hydraulic } \\
\text { Diameter }\end{array}$ & $\begin{array}{c}\text { Wall } \\
\text { Roughness }\end{array}$ & $\begin{array}{l}\text { Lower } \\
\text { Elevation }\end{array}$ & $\begin{array}{l}\text { Upper } \\
\text { Elevation }\end{array}$ \\
\hline & & & [m] & {$\left[\mathrm{m}^{2}\right]$} & {$\left[\mathrm{m}^{3}\right]$} & {$[\mathrm{m}]$} & {$[\mathrm{m}]$} & {$[\mathrm{m}]$} & {$[\mathrm{m}]$} \\
\hline 8 & Branch & 1 & 1.0660 & 0.72327 & 0.7710 & 0.30300 & $3.20 \mathrm{E}-06$ & 1.7532 & 2.8192 \\
\hline 10 & Snglvol & 1 & 1.4088 & 2.34242 & 3.3000 & 0.30470 & $3.20 \mathrm{E}-06$ & 2.8192 & 4.2279 \\
\hline 12 & Snglvol & 1 & 1.8082 & 1.09513 & 1.9802 & 0.14800 & $3.20 \mathrm{E}-06$ & 1.0109 & 2.8192 \\
\hline 14 & Snglvol & 1 & 0.5537 & 0.34296 & 0.1899 & 0.04800 & $3.20 \mathrm{E}-06$ & 0.4572 & 1.0109 \\
\hline \multirow{5}{*}{16} & \multirow{5}{*}{ Pipe } & 1 & 0.0762 & \multirow{5}{*}{0.03860} & \multirow{5}{*}{0.0353} & \multirow{5}{*}{0.00710} & \multirow{5}{*}{$3.20 \mathrm{E}-06$} & \multirow{5}{*}{-0.4572} & \multirow{5}{*}{0.4572} \\
\hline & & 2 & 0.0381 & & & & & & \\
\hline & & $\ldots$ & $\ldots$ & & & & & & \\
\hline & & 21 & 0.0381 & & & & & & \\
\hline & & 22 & 0.0762 & & & & & & \\
\hline 18 & Snglvol & 1 & 0.4438 & 0.41685 & 0.1850 & 0.05900 & $3.20 \mathrm{E}-06$ & -0.901 & -0.4572 \\
\hline 20 & Snglvol & 1 & 1.5374 & 0.66021 & 1.0150 & 0.09500 & $3.20 \mathrm{E}-06$ & -2.4384 & -0.901 \\
\hline 22 & Snglvol & 1 & 2.5130 & 3.18300 & 7.9989 & 2.01000 & $3.20 \mathrm{E}-06$ & -4.9519 & -2.4384 \\
\hline 24 & Branch & 1 & 1.6772 & 1.06666 & 1.7890 & 0.36400 & $3.20 \mathrm{E}-06$ & -2.4384 & -0.7612 \\
\hline
\end{tabular}

Table B-2 Description of junction for the bypass channel

\begin{tabular}{|c|c|c|c|c|c|c|c|c|c|c|c|}
\hline $\begin{array}{c}\text { RELAP5 } \\
\#\end{array}$ & Type & $\begin{array}{c}\text { Junction } \\
\#\end{array}$ & From & Type & To & Type & $\begin{array}{l}\text { Hydraulic } \\
\text { Diameter }\end{array}$ & Area & $\begin{array}{l}\text { Abrupt } \\
\text { Area } \\
\text { Change }\end{array}$ & $\begin{array}{c}\text { Forward } \\
\qquad \mathrm{K}\end{array}$ & $\begin{array}{c}\text { Reverse } \\
\mathrm{K}\end{array}$ \\
\hline & & & & & & & {$[\mathrm{m}]$} & {$\left[\mathrm{m}^{2}\right]$} & & {$[-]$} & {$[-]$} \\
\hline 951 & Sngljun & 1 & 255 & Outlet & 8 & Crossflow & 0.581 & 0.265142 & No & 0 & 0 \\
\hline 953 & Sngljun & 1 & 265 & Outlet & 8 & Crossflow & 0.581 & 0.265142 & No & 0 & 0 \\
\hline 8 & Branch & 1 & 8 & Outlet & 10 & Inlet & 0 & 0 & Yes & 0 & 0 \\
\hline 12 & Branch & 1 & 10 & Inlet & 12 & Inlet & 0 & 0 & No & 0 & 0 \\
\hline \multirow{2}{*}{14} & \multirow{2}{*}{ Branch } & 1 & 12 & Outlet & 14 & Inlet & 0.0178 & 0.14 & No & 1.04 & 1.04 \\
\hline & & 2 & 14 & Outlet & 16 & Inlet & 0 & 0 & No & 0 & 0 \\
\hline 18 & Branch & 1 & 16 & Outlet & 18 & Inlet & 0 & 0 & No & 0 & 0 \\
\hline \multirow{2}{*}{20} & \multirow{2}{*}{ Branch } & 1 & 18 & Outlet & 20 & Inlet & 0.018 & 0.144 & No & 0.9 & 0.82 \\
\hline & & 2 & 20 & Outlet & 24 & Inlet & 0.088 & 0.146 & No & 2.22 & 2.07 \\
\hline \multirow{3}{*}{24} & \multirow{3}{*}{ Branch } & 1 & 22 & Outlet & 24 & Inlet & 0.364 & 1.138 & No & 0.33 & 0.41 \\
\hline & & 2 & 24 & Crossflow & 201 & Inlet & 0.581 & 0.265412 & No & 1.28 & 1.66 \\
\hline & & 3 & 24 & Crossflow & 211 & Inlet & 0.581 & 0.265412 & No & 1.28 & 1.66 \\
\hline 991 & Sngljun & 1 & 24 & Crossflow & 201 & Inlet & 0.581 & 0.265412 & No & 1.28 & 1.66 \\
\hline 992 & Sngljun & 1 & 24 & Crossflow & 211 & Inlet & 0.581 & 0.265412 & No & 1.28 & 1.66 \\
\hline
\end{tabular}




\section{B.2 High heat flux fuel channel (1963 core)}

The high heat flux channel represents the coolant within a single $84 \mathrm{~mm}$ channel containing a fuel assembly with the highest heat flux. It is comprised of coolant volumes 30 through 40 . Within the core region volume 36 was split into 4 components (Figure 6) corresponding to the hot stripe heat structures and remainder of the fuel assembly to be more conservative relative to the enthalpy change across the fuel. The components corresponding to the hot stripe were also determined based on a 10 degree arc length for the outer 3 sub-channels. Volumes 365,366 and 367 represent the $5^{\text {th }}, 6^{\text {th }}$ and $7^{\text {th }}$ sub channel, respectively. Volume 360 represents the remainder of the channels within the high heat flux fuel assembly. The following is a description of the junctions within the high heat flux channel.

\section{Junctions of branch 32}

The junction between volumes 30 and 32 was modeled based on the smaller flow area of the two volumes and the abrupt area change modeled was used to determine pressure losses.

Cross flow between volumes 12 and 32 occurs through 480 holes with a diameter of $6.35 \mathrm{~mm}$. The holes are arranged such that there are 6 per axial location at 80 different elevations with an axial distance of $0.0195 \mathrm{~m}$. The total cross sectional flow area was calculated to be $0.0152 \mathrm{~m}^{2}$ and the hydraulic diameter was specified as the diameter of the holes. The forward and reverse loss coefficients were determined to be 2.76 based on the following formula for sharp edged orifices:

$k_{\text {forward }}=k_{\text {backward }}=\left(1+0.707 \sqrt{1-\frac{F 0}{F 1}}-\frac{F 0}{F 2}\right)^{2} ; \quad \frac{F 0}{F 1}=\frac{F 0}{F 2}=\frac{0.00019}{0.0058}$

\section{Junctions of branch 34}

The junction between volume 32 and 34 was modeled based on the smaller flow area of the two volumes.

Cross flow between volumes 14 and 34 occurs through 60 holes with a diameter of $4.76 \mathrm{~mm}$. There are 6 holes per axial location and are separated axially of $0.027 \mathrm{~m}$. The total flow area was calculated to be $0.0011 \mathrm{~m}$ and the hydraulic diameter was based on the diameter of the holes. The forward and reverse flow loss coefficients were determined to be 2.85 based on the following formula for sharp edged orifices:

$k_{\text {forward }}=k_{\text {backward }}=\left(1+0.707 \sqrt{1-\frac{F 0}{F 1}}-\frac{F 0}{F 2}\right)^{2} ; \quad \frac{F 0}{F 1}=\frac{F 0}{F 2}=\frac{0.00011}{0.0077}$

The junctions at the core inlet (34-360, 34-365, 34-366, 34-367) were based on the smaller flow areas for each and the abrupt area change model was not used as these loss coefficients were determined by the calibration process described in Section 3. 


\section{Junctions of branch 38}

The junctions at the core exit (360-38, 365-38, 366-38, 367-38) were based on the smaller flow areas for each the abrupt area change model was not used as these loss coefficients were determined by the calibration process described in Section 2.6.4.

Cross flow between volumes 38 and 18 was modeled with 60 holes having a diameter of $0.00635 \mathrm{~m}$. There are 6 holes per elevation and an axial spacing of $0.027 \mathrm{~m}$. The total flow area was calculated to be $0.0019 \mathrm{~m}$ and the hydraulic diameter was based on the diameter of the holes. The forward and reverse flow loss coefficients were determined to be 2.80 based on the sharp edged orifice formula:

$k_{\text {forward }}=k_{\text {backward }}=\left(1+0.707 \sqrt{1-\frac{F 0}{F 1}}-\frac{F 0}{F 2}\right)^{2} ; \quad \frac{F 0}{F 1}=\frac{F 0}{F 2}=\frac{0.00019}{0.0077}$

\section{Junctions of branch 40}

The hydraulic junction between volumes 40 and 22 was characteristic of thick edged orifice with flow area of $0.0038 \mathrm{~m}^{2}$ and hydraulic diameter of $0.07 \mathrm{~m}$. The reverse and forward loss coefficients were calculated to be 1.18 and 1.56, respectively, based on the following correlation for a thick edged orifice:

$k=0.5\left(1-\frac{F 0}{F 1}\right)+\left(1-\frac{F 0}{F 2}\right)^{2}+\tau \sqrt{1-\frac{F 0}{F 1}\left(1-\frac{F 0}{F 2}\right)} ; \quad \tau=0.12 ; \quad \frac{F 0}{F 1}=\frac{0.0038}{0.0050} ; \quad \frac{F 0}{F 2}=\frac{0.0038}{3.18}$ 
Table B-3 Hydraulic parameters for high heat flux fuel channel volumes

\begin{tabular}{|c|c|c|c|c|c|c|c|c|c|}
\hline $\begin{array}{c}\text { RELAP5 } \\
\#\end{array}$ & Type & Node & $\begin{array}{l}\text { Actual } \\
\text { Length }\end{array}$ & Flow Area & Volume & $\begin{array}{l}\text { Hydraulic } \\
\text { Diameter }\end{array}$ & $\begin{array}{c}\text { Wall } \\
\text { Roughness }\end{array}$ & $\begin{array}{l}\text { Lower } \\
\text { Elevation }\end{array}$ & $\begin{array}{c}\text { Upper } \\
\text { Elevation }\end{array}$ \\
\hline & & & [m] & {$\left[\mathrm{m}^{2}\right]$} & {$\left[\mathrm{m}^{3}\right]$} & {$[\mathrm{m}]$} & [m] & {$[\mathrm{mm}]$} & {$[\mathrm{m}]$} \\
\hline 30 & Snglvol & 1 & 1.6028 & 0.00564 & 0.00904 & 0.04212 & $1.60 \mathrm{E}-06$ & 2.8191 & 4.4219 \\
\hline 32 & Branch & 1 & 1.8082 & 0.00558 & 0.01009 & 0.04180 & $1.60 \mathrm{E}-06$ & 1.0109 & 2.8191 \\
\hline 34 & Branch & 1 & 0.5537 & 0.00463 & 0.00256 & 0.03661 & $1.60 \mathrm{E}-06$ & 0.4572 & 1.0109 \\
\hline \multirow{5}{*}{360} & \multirow{5}{*}{ Pipe } & 1 & 0.0762 & \multirow{5}{*}{$3.415 \mathrm{E}-03$} & $2.618 \mathrm{E}-04$ & \multirow{5}{*}{0.00574} & \multirow{5}{*}{$1.60 \mathrm{E}-06$} & \multirow{20}{*}{-0.4572} & \multirow{20}{*}{0.4572} \\
\hline & & 2 & 0.0381 & & $1.309 \mathrm{E}-04$ & & & & \\
\hline & & $\ldots$ & $\ldots$ & & $\ldots$ & & & & \\
\hline & & 21 & 0.0381 & & $1.309 \mathrm{E}-04$ & & & & \\
\hline & & 22 & 0.0762 & & $2.618 \mathrm{E}-04$ & & & & \\
\hline \multirow{5}{*}{365} & \multirow{5}{*}{ Pipe } & 1 & 0.0762 & \multirow{5}{*}{$1.646 \mathrm{E}-05$} & $1.254 \mathrm{E}-06$ & \multirow{5}{*}{0.00598} & \multirow{5}{*}{$1.60 \mathrm{E}-06$} & & \\
\hline & & 2 & 0.0381 & & $6.272 \mathrm{E}-07$ & & & & \\
\hline & & $\ldots$ & $\ldots$ & & $\ldots$ & & & & \\
\hline & & 21 & 0.0381 & & $6.272 \mathrm{E}-07$ & & & & \\
\hline & & 22 & 0.0762 & & $1.254 \mathrm{E}-06$ & & & & \\
\hline \multirow{5}{*}{366} & \multirow{5}{*}{ Pipe } & 1 & 0.0762 & \multirow{5}{*}{$1.875 \mathrm{E}-05$} & $1.429 \mathrm{E}-06$ & \multirow{5}{*}{0.00600} & \multirow{5}{*}{$1.60 \mathrm{E}-06$} & & \\
\hline & & 2 & 0.0381 & & $7.144 \mathrm{E}-07$ & & & & \\
\hline & & $\ldots$ & $\ldots$ & & $\ldots$ & & & & \\
\hline & & 21 & 0.0381 & & $7.144 \mathrm{E}-07$ & & & & \\
\hline & & 22 & 0.0762 & & $1.429 \mathrm{E}-06$ & & & & \\
\hline \multirow{5}{*}{367} & \multirow{5}{*}{ Pipe } & 1 & 0.0762 & \multirow{5}{*}{$2.479 \mathrm{E}-05$} & $1.889 \mathrm{E}-06$ & \multirow{5}{*}{0.00704} & \multirow{5}{*}{$1.60 \mathrm{E}-06$} & & \\
\hline & & 2 & 0.0381 & & $9.444 \mathrm{E}-07$ & & & & \\
\hline & & $\ldots$ & $\ldots$ & & $\ldots$ & & & & \\
\hline & & 21 & 0.0381 & & $9.444 \mathrm{E}-07$ & & & & \\
\hline & & 22 & 0.0762 & & $1.889 \mathrm{E}-06$ & & & & \\
\hline 38 & Branch & 1 & 0.4438 & 0.00497 & 0.00221 & 0.04837 & $1.60 \mathrm{E}-06$ & -0.9010 & -0.4572 \\
\hline 40 & Branch & 1 & 1.5374 & 0.00497 & 0.00765 & 0.07961 & $1.60 \mathrm{E}-06$ & -2.4384 & -0.9010 \\
\hline
\end{tabular}


Table B-4 Junction parameters for high heat flux fuel channel volumes

\begin{tabular}{|c|c|c|c|c|c|c|c|c|c|c|c|}
\hline $\begin{array}{c}\text { RELAP5 } \\
\#\end{array}$ & Type & $\begin{array}{c}\text { Junction } \\
\#\end{array}$ & From & Type & To & Type & $\begin{array}{l}\text { Hydraulic } \\
\text { Diameter }\end{array}$ & Area & $\begin{array}{c}\text { Abrupt } \\
\text { Area } \\
\text { Change }\end{array}$ & $\begin{array}{c}\text { Forward } \\
\mathrm{K}\end{array}$ & $\begin{array}{c}\text { Reverse } \\
\text { K }\end{array}$ \\
\hline & & & & & & & {$[\mathrm{m}]$} & {$\left[\mathrm{m}^{2}\right]$} & & {$[-]$} & {$[-]$} \\
\hline \multirow{2}{*}{32} & \multirow{2}{*}{ Branch } & 1 & 30 & Inlet & 32 & Inlet & 0 & 0 & Yes & 0 & 0 \\
\hline & & 2 & 32 & Crossflow & 12 & Crossflow & 0.00635 & 0.01520 & No & 2.76 & 2.76 \\
\hline \multirow{6}{*}{34} & \multirow{6}{*}{ Branch } & 1 & 32 & Outlet & 34 & Inlet & 0 & 0 & No & 0 & 0 \\
\hline & & 2 & 34 & Crossflow & 14 & Crossflow & 0.00476 & $1.068 \mathrm{E}-03$ & No & 2.85 & 2.85 \\
\hline & & 3 & 34 & Outlet & 360 & Inlet & 0 & 0 & No & 0 & 0 \\
\hline & & 4 & 34 & Outlet & 365 & Inlet & 0 & 0 & No & 0 & 0 \\
\hline & & 5 & 34 & Outlet & 366 & Inlet & 0 & 0 & No & 0 & 0 \\
\hline & & 6 & 34 & Outlet & 367 & Inlet & 0 & 0 & No & 0 & 0 \\
\hline \multirow{5}{*}{38} & \multirow{5}{*}{ Branch } & 1 & 360 & Outlet & 38 & Inlet & 0 & 0 & No & 0 & 0 \\
\hline & & 2 & 365 & Outlet & 38 & Inlet & 0 & 0 & No & 0 & 0 \\
\hline & & 3 & 366 & Outlet & 38 & Inlet & 0 & 0 & No & 0 & 0 \\
\hline & & 4 & 367 & Outlet & 38 & Inlet & 0 & 0 & No & 0 & 0 \\
\hline & & 5 & 38 & Crossflow & 18 & Crossflow & 0.00635 & 1.900E-03 & No & 2.8 & 2.8 \\
\hline \multirow{2}{*}{40} & \multirow{2}{*}{ Branch } & 1 & 38 & Outlet & 40 & Inlet & 0 & 0 & Yes & 0 & 0 \\
\hline & & 2 & 40 & Outlet & 22 & Inlet & 0 & 0 & No & 1.18 & 1.56 \\
\hline
\end{tabular}

\section{B.3 Average fuel channel (1963 core)}

The average fuel channel is comprised of coolant volumes 50 to 60 . The junctions and volumes are identical to the high heat flux fuel channel except that the cross sectional flow areas were based on 13 channels with fuel elements instead of 1 and the core region (volume 56) wasn't expanded into multiple components.

Table B-5 Hydraulic parameters for average fuel channel volumes

\begin{tabular}{|c|c|c|c|c|c|c|c|c|c|}
\hline $\begin{array}{c}\text { RELAP5 } \\
\#\end{array}$ & Type & Node & $\begin{array}{l}\text { Actual } \\
\text { Length }\end{array}$ & Flow Area & Volume & $\begin{array}{l}\text { Hydraulic } \\
\text { Diameter }\end{array}$ & $\begin{array}{c}\text { Wall } \\
\text { Roughness }\end{array}$ & $\begin{array}{l}\text { Lower } \\
\text { Elevation }\end{array}$ & $\begin{array}{c}\text { Upper } \\
\text { Elevation }\end{array}$ \\
\hline & & & [m] & {$\left[\mathrm{m}^{2}\right]$} & {$\left[\mathrm{m}^{3}\right]$} & [m] & [m] & [m] & [m] \\
\hline 50 & Snglvol & 1 & 1.6028 & 0.07328 & 0.11746 & 0.04212 & $1.60 \mathrm{E}-06$ & 2.8191 & 4.4219 \\
\hline 52 & Branch & 1 & 1.8082 & 0.07257 & 0.13122 & 0.04180 & $1.60 \mathrm{E}-06$ & 1.0109 & 2.8191 \\
\hline 54 & Branch & 1 & 0.5537 & 0.06021 & 0.03334 & 0.03661 & $1.60 \mathrm{E}-06$ & 0.4572 & 1.0109 \\
\hline \multirow{5}{*}{56} & \multirow{5}{*}{ Pipe } & 1 & 0.0762 & \multirow{5}{*}{0.04544} & 0.00346 & \multirow{5}{*}{0.00583} & \multirow{5}{*}{$1.60 \mathrm{E}-06$} & \multirow{5}{*}{-0.4572} & \multirow{5}{*}{0.4572} \\
\hline & & 2 & 0.0381 & & 0.00173 & & & & \\
\hline & & $\ldots$ & $\ldots$ & & $\ldots$ & & & & \\
\hline & & 21 & 0.0381 & & 0.00173 & & & & \\
\hline & & 22 & 0.0762 & & 0.00346 & & & & \\
\hline 58 & Branch & 1 & 0.4438 & 0.06464 & 0.02869 & 0.04837 & $1.60 \mathrm{E}-06$ & -0.9010 & -0.4572 \\
\hline 60 & Branch & 1 & 1.5374 & 0.06466 & 0.09940 & 0.07961 & 1.60E-06 & -2.4384 & -0.9010 \\
\hline
\end{tabular}


Table B-6 Junction parameters for average fuel channel volumes

\begin{tabular}{|c|c|c|c|c|c|c|c|c|c|c|c|}
\hline $\begin{array}{c}\text { RELAP5 } \\
\quad \#\end{array}$ & Type & $\begin{array}{c}\text { Junction } \\
\#\end{array}$ & From & Type & To & Type & $\begin{array}{l}\text { Hydraulic } \\
\text { Diameter }\end{array}$ & Area & $\begin{array}{l}\text { Abrupt } \\
\text { Area } \\
\text { Change }\end{array}$ & $\begin{array}{c}\text { Forward } \\
\mathrm{K}\end{array}$ & $\begin{array}{c}\text { Reverse } \\
\mathrm{K}\end{array}$ \\
\hline & & & & & & & [m] & {$\left[\mathrm{m}^{2}\right]$} & & {$[-]$} & {$[-]$} \\
\hline \multirow{2}{*}{52} & \multirow{2}{*}{ Branch } & 1 & 52 & Inlet & 50 & Inlet & 0 & 0 & Yes & 0 & 0 \\
\hline & & 2 & 12 & Crossflow & 52 & Crossflow & 0.00635 & 0.19762 & No & 2.76 & 2.76 \\
\hline \multirow{3}{*}{54} & \multirow{3}{*}{ Branch } & 1 & 52 & Outlet & 54 & Inlet & 0 & 0 & No & 0 & 0 \\
\hline & & 2 & 14 & Crossflow & 54 & Crossflow & 0.00476 & 0.01388 & No & 2.85 & 2.85 \\
\hline & & 3 & 54 & Outlet & 56 & Inlet & 0 & 0 & No & 0 & 0 \\
\hline \multirow{2}{*}{58} & \multirow{2}{*}{ Branch } & 1 & 56 & Outlet & 58 & Inlet & 0 & 0 & No & 0 & 0 \\
\hline & & 2 & 18 & Crossflow & 58 & Crossflow & 0.00635 & 0.02470 & No & 2.8 & 2.8 \\
\hline \multirow{2}{*}{60} & \multirow{2}{*}{ Branch } & 1 & 58 & Outlet & 60 & Inlet & 0 & 0 & Yes & 0 & 0 \\
\hline & & 2 & 60 & Outlet & 22 & Inlet & 0 & 0 & No & 1.18 & 1.56 \\
\hline
\end{tabular}

\section{B.4 Plugged channel (1963 core)}

The plugged channel is comprised of coolant volumes 70 through 80 . The geometric and hydraulic parameters for this channel was a consolidation of 10 plugged $50 \mathrm{~mm}$ channels, 9 control rods in $84 \mathrm{~mm}$ channels and 5 plugged $200 \mathrm{~mm}$ channels. The strategy employed for obtaining a representative channel was to first determine the geometric and hydraulic parameters for each channel for each of the 6 coolant volume elevations. The representative flow area for each elevation was then determined from the sum each channel type. The hydraulic diameter was determined from the following equation:

$$
D_{h}=\frac{\sum_{1}^{i} D_{h, i} N_{i}}{\sum_{1}^{i} N_{i}}
$$

where the subscript " $\mathrm{i}$ " was used to indicate channel type and " $\mathrm{N}$ " was the number of channels for that type. The plugged channel parameters are given in Table B-7. The following is a brief description of each of the junctions.

\section{Junctions of branch 72}

The junction between volume 70 and 72 was modeled based on the smaller flow area of the two volumes and the abrupt area change modeled was used to determine pressure losses.

Cross flow between volumes 12 and 72 was occurs through perforations in the three channel types: $50 \mathrm{~mm}=480$ holes, $84 \mathrm{~mm}=480$ holes and $200 \mathrm{~mm}=1368$. The holes in this section have a diameter of $6.35 \mathrm{~mm}$ with axial spacing of $0.0195 \mathrm{~m}$. The total cross sectional area for the 1963 core was $1.1287 \mathrm{~m}^{2}$ and the hydraulic diameter was specified as the characteristic hole diameter. The forward and reverse loss coefficients were determined to be 2.78 based on the following formula for sharp edged orifices:

$k_{\text {forward }}=k_{\text {backward }}=\left(1+0.707 \sqrt{1-\frac{F 0}{F 1}}-\frac{F 0}{F 2}\right)^{2} ; \quad \frac{F 0}{F 1}=\frac{F 0}{F 2}=\frac{0.00877}{0.2997}$

Junctions of branch 74 
The junction between volume 72 and 74 was modeled based on the smaller flow area of the two volumes.

Cross flow between volumes 14 and 74 was possible through perforations in the three channel types: $50 \mathrm{~mm}=60,84 \mathrm{~mm}=60$ and $200 \mathrm{~mm}=330$. The $50 \mathrm{~mm}$ and $200 \mathrm{~mm}$ channels had hole diameters of $6.35 \mathrm{~mm}$ while the $84 \mathrm{~mm}$ channel had hole diameters of $4.76 \mathrm{~mm}$. The total flow area was $0.1247 \mathrm{~m}$ and the hydraulic diameter $(0.00556 \mathrm{~m})$ was based on a number average. The forward and reverse flow loss coefficients were determined to be 2.85 based on the sharp edged orifice formula:

$k_{\text {forward }}=k_{\text {backward }}=\left(1+0.707 \sqrt{1-\frac{F 0}{F 1}}-\frac{F 0}{F 2}\right)^{2} ; \quad \frac{F 0}{F 1}=\frac{F 0}{F 2}=\frac{0.00877}{0.33872}$

Flow into the core region utilized the hydraulic diameter and flow area of volume 76 . The abrupt area change model was not used as these losses were determined by the calibration process described in Section 2.6.4.

Junctions of branch 78

Flow out of the core region utilized the hydraulic diameter and flow area of volume 76. The abrupt area change model was not used as these losses were determined by the calibration process described in Section 2.6.4.

Cross flow between volumes 78 and 18 was similar to that 74 and 14 except the $84 \mathrm{~mm}$ channels had hole diameters of $6.35 \mathrm{~mm}$. The hydraulic diameter was based on the diameter of the holes. The forward and reverse flow loss coefficient remained 2.80 .

Junctions of branch 80

The junction between volume 78 and 80 was modeled based on the smaller flow area of the two volumes and the abrupt area change modeled was used to determine pressure losses.

The hydraulic junction between volumes 80 and 22 was characteristic of a thick edged orifice and included all three channel sizes. The upstream channel diameters were $0.0472 \mathrm{~m}, 0.0801 \mathrm{~m}$ and $0.2036 \mathrm{~m}$, respectively. The orifice diameters were $0.0349 \mathrm{~m}, 0.0699 \mathrm{~m}$ and $0.2036 \mathrm{~m}$, respectively. The downstream area was based on that specified for volume 22. The flow area and hydraulic diameter were based on the upstream geometry. The reverse and forward loss coefficients were calculated to be 0.86 and 0.47 , respectively, based on the following correlation (last term has been omitted due to negligible effect):

$k=0.5\left(1-\frac{F 0}{F 1}\right)+\left(1-\frac{F 0}{F 2}\right)^{2} ; \quad \tau=0.12 ; \quad \frac{F 0}{F 1}=\frac{0.364}{0.432} ; \quad \frac{F 0}{F 2}=\frac{0.364}{3.18}$ 
Table B-7 Hydraulic parameters for plugged channel volumes

\begin{tabular}{|c|c|c|c|c|c|c|c|c|c|}
\hline $\begin{array}{c}\text { RELAP5 } \\
\#\end{array}$ & Type & Node & $\begin{array}{l}\text { Actual } \\
\text { Length }\end{array}$ & Flow Area & Volume & $\begin{array}{l}\text { Hydraulic } \\
\text { Diameter }\end{array}$ & $\begin{array}{c}\text { Wall } \\
\text { Roughness }\end{array}$ & $\begin{array}{l}\text { Lower } \\
\text { Elevation }\end{array}$ & $\begin{array}{c}\text { Upper } \\
\text { Elevation }\end{array}$ \\
\hline & & & [m] & {$\left[\mathrm{m}^{2}\right]$} & {$\left[\mathrm{m}^{3}\right]$} & [m] & [m] & [m] & {$[\mathrm{m}]$} \\
\hline 70 & Snglvol & 1 & 1.6028 & 0.46425 & 0.74412 & 0.03648 & $1.60 \mathrm{E}-06$ & 2.8191 & 4.4219 \\
\hline 72 & Branch & 1 & 1.8082 & 0.46231 & 0.83595 & 0.03629 & $1.60 \mathrm{E}-06$ & 1.0109 & 2.8191 \\
\hline 74 & Branch & 1 & 0.5537 & 0.24599 & 0.13621 & 0.01898 & $1.60 \mathrm{E}-06$ & 0.4572 & 1.0109 \\
\hline \multirow{5}{*}{76} & \multirow{5}{*}{ Pipe } & 1 & 0.0762 & \multirow{5}{*}{0.06394} & 0.00487 & \multirow{5}{*}{0.00448} & \multirow{5}{*}{$1.60 \mathrm{E}-06$} & \multirow{5}{*}{-0.4572} & \multirow{5}{*}{0.4572} \\
\hline & & 2 & 0.0381 & & 0.00244 & & & & \\
\hline & & $\cdots$ & $\cdots$ & & $\cdots$ & & & & \\
\hline & & 21 & 0.0381 & & 0.00244 & & & & \\
\hline & & 22 & 0.0762 & & 0.00487 & & & & \\
\hline 78 & Branch & 1 & 0.4438 & 0.27170 & 0.12058 & 0.02924 & $1.60 \mathrm{E}-06$ & -0.9010 & -0.4572 \\
\hline 80 & Branch & 1 & 1.5374 & 0.42856 & 0.65888 & 0.08410 & $1.60 \mathrm{E}-06$ & -2.4384 & -0.9010 \\
\hline
\end{tabular}

Table B-8 Junction parameters for plugged channel volumes

\begin{tabular}{|c|c|c|c|c|c|c|c|c|c|c|c|}
\hline $\begin{array}{c}\text { RELAP5 } \\
\#\end{array}$ & Type & $\begin{array}{c}\text { Junction } \\
\#\end{array}$ & From & Type & To & Type & $\begin{array}{l}\text { Hydraulic } \\
\text { Diameter }\end{array}$ & Area & $\begin{array}{c}\text { Abrupt } \\
\text { Area } \\
\text { Change }\end{array}$ & $\begin{array}{c}\text { Forward } \\
\mathrm{K}\end{array}$ & $\begin{array}{c}\text { Reverse } \\
\mathrm{K}\end{array}$ \\
\hline & & & & & & & [m] & {$\left[\mathrm{m}^{2}\right]$} & & {$[-]$} & {$[-]$} \\
\hline \multirow{2}{*}{72} & \multirow{2}{*}{ Branch } & 1 & 72 & Inlet & 70 & Inlet & 0 & 0 & Yes & 0 & 0 \\
\hline & & 2 & 12 & Crossflow & 72 & Crossflow & 0.00635 & 1.12869 & No & 2.78 & 2.78 \\
\hline \multirow{3}{*}{74} & \multirow{3}{*}{ Branch } & 1 & 72 & Outlet & 74 & Inlet & 0 & 0 & No & 0 & 0 \\
\hline & & 2 & 14 & Crossflow & 74 & Crossflow & 0.00556 & 0.12468 & No & 2.80 & 2.80 \\
\hline & & 3 & 74 & Outlet & 76 & Inlet & 0 & 0 & No & 0 & 0 \\
\hline \multirow{2}{*}{78} & \multirow{2}{*}{ Branch } & 1 & 76 & Outlet & 78 & Inlet & 0 & 0 & No & 0 & 0 \\
\hline & & 2 & 18 & Crossflow & 78 & Crossflow & 0.00635 & 0.16626 & No & 2.8 & 2.8 \\
\hline \multirow{2}{*}{80} & \multirow{2}{*}{ Branch } & 1 & 78 & Outflow & 80 & Inflow & 0 & 0 & Yes & 0 & 0 \\
\hline & & 2 & 80 & Outflow & 22 & Inflow & 0 & 0 & No & 0.86 & 0.47 \\
\hline
\end{tabular}




\section{B.5 Vessel Shroud}

The reactor vessel is cooled in the core region by a separate coolant system that supplies cooling water from the pool. Coolant flows upward along the exterior of the reactor vessel (volume 166) and is discharged back into the pool. The information provided here is different from previous RELAP5 models in that the flow area and hydraulic diameter of the core region was applied to all elevations. At the time of this document information was not available to verify the parameters in the following tables.

Table B-9 Hydraulic parameter for reactor vessel cooling shroud

\begin{tabular}{|c|c|c|c|c|c|c|c|c|c|}
\hline RELAP \# & Type & Node & $\begin{array}{l}\text { Actual } \\
\text { Length }\end{array}$ & Flow Area & Volume & $\begin{array}{l}\text { Hydraulic } \\
\text { Diameter }\end{array}$ & $\begin{array}{c}\text { Wall } \\
\text { Roughness }\end{array}$ & $\begin{array}{c}\text { Lower } \\
\text { Elevation }\end{array}$ & $\begin{array}{c}\text { Upper } \\
\text { Elevation }\end{array}$ \\
\hline & & & {$[\mathrm{m}]$} & {$\left[\mathrm{m}^{2}\right]$} & {$\left[\mathrm{m}^{3}\right]$} & {$[\mathrm{m}]$} & {$[\mathrm{m}]$} & {$[\mathrm{m}]$} & {$[\mathrm{m}]$} \\
\hline 160 & TMDPVOL & 1 & 10 & 10 & 100 & & & 1.9630 & 1.9630 \\
\hline \multirow{14}{*}{166} & \multirow{14}{*}{ Pipe } & 1 & 0.08200 & 0.24934 & 0.02181 & 0.07678 & $3.20 \mathrm{E}-06$ & 1.8810 & 1.9630 \\
\hline & & 2 & 0.14732 & 0.62281 & 0.09175 & 0.21280 & $3.20 \mathrm{E}-06$ & 1.7337 & 1.8810 \\
\hline & & 3 & 0.12890 & 0.45945 & 0.05922 & 0.13910 & $3.20 \mathrm{E}-06$ & 1.6048 & 1.7337 \\
\hline & & 4 & 0.59386 & 0.12212 & 0.07253 & 0.04911 & $3.20 \mathrm{E}-06$ & 1.0109 & 1.6048 \\
\hline & & 5 & 0.55370 & 0.05683 & 0.03139 & 0.02750 & $3.20 \mathrm{E}-06$ & 0.4572 & 1.0109 \\
\hline & & 6 & 0.07669 & \multirow{5}{*}{0.04507} & 0.00346 & \multirow{5}{*}{0.02462} & $3.20 \mathrm{E}-06$ & \multirow{5}{*}{-0.4572} & \multirow{5}{*}{0.4572} \\
\hline & & 7 & 0.03805 & & 0.00171 & & $3.20 \mathrm{E}-06$ & & \\
\hline & & $\ldots$ & $\ldots$ & & $\ldots$ & & $\ldots$ & & \\
\hline & & 26 & 0.03805 & & 0.00171 & & $3.20 \mathrm{E}-06$ & & \\
\hline & & 27 & 0.07669 & & 0.00346 & & $3.20 \mathrm{E}-06$ & & \\
\hline & & 28 & 0.44380 & 0.07924 & 0.03538 & 0.03606 & $3.20 \mathrm{E}-06$ & -0.9010 & -0.4572 \\
\hline & & 29 & 1.17392 & 0.78245 & 0.91853 & 0.23357 & $3.20 \mathrm{E}-06$ & -2.0749 & -0.9010 \\
\hline & & 30 & 0.36368 & 1.35860 & 0.49410 & 0.35412 & $3.20 \mathrm{E}-06$ & -2.4386 & -2.0749 \\
\hline & & 31 & 0.19335 & 1.02351 & 0.19790 & 0.27038 & $3.20 \mathrm{E}-06$ & -2.6320 & -2.4386 \\
\hline 170 & TMDPVOL & 1 & 10 & 10 & 100 & & & -2.6320 & -2.6320 \\
\hline
\end{tabular}

Table B-10 RELAP5 junction table summary

\begin{tabular}{|c|c|c|c|c|c|c|c|c|c|c|c|}
\hline $\begin{array}{c}\text { RELAP5 } \\
\#\end{array}$ & Type & $\begin{array}{c}\text { Junction } \\
\#\end{array}$ & From & Type & To & Type & $\begin{array}{c}\text { Hydraulic } \\
\text { Diameter }\end{array}$ & Area & $\begin{array}{c}\text { Abrupt } \\
\text { Area } \\
\text { Change }\end{array}$ & $\begin{array}{c}\text { Forward } \\
\mathrm{K}\end{array}$ & $\begin{array}{c}\text { Reverse } \\
\mathrm{K}\end{array}$ \\
\hline & & & & & & & {$[\mathrm{m}]$} & {$\left[\mathrm{m}^{2}\right]$} & & {$[-]$} & {$[-]$} \\
\hline 161 & TMDPJUN & 1 & 160 & Outflow & 166 & Inflow & & 0.03533 & & & \\
\hline 169 & SNGLUN & 1 & 166 & Outflow & 170 & Inflow & 0.0194 & 0 & No & 0.5 & 0.5 \\
\hline
\end{tabular}




\section{Power Specifications for 1963 Tests}

Table C-1 Power specifications for Test A/400/1 [12]

\begin{tabular}{|c|c|c|c|c|c|c|c|c|c|c|c|c|c|}
\hline \multirow{2}{*}{\multicolumn{2}{|c|}{$\begin{array}{r}\text { Test A/400/1 } \\
\text { Component }\end{array}$}} & \multicolumn{3}{|c|}{ Remainder of High Heat Flux } & \multicolumn{4}{|c|}{ High heat flux } & \multicolumn{3}{|c|}{ Average Fuel } & \multicolumn{2}{|c|}{ Plugged Channel } \\
\hline & & Structure & Beryllium & Fuel & $\begin{array}{l}\text { Plate } 4 \\
\end{array}$ & Plate 5 & Plate 6 & Beryllium & Structure & Beryllium & Fuel & Structure & Beryllium \\
\hline \multicolumn{2}{|c|}{$\begin{array}{r}\text { RELAP5 Volume } \\
\text { Connections (left/Right) } \\
\end{array}$} & Sym-360 & $360-16$ & $360-360$ & $360-365$ & $365-366$ & 366-367 & $367-16$ & Sym-56 & $56-16$ & Sym-56 & Sym-76 & $76-16$ \\
\hline \multicolumn{2}{|c|}{ Heat Structure } & 301 & 368 & 360 & 364 & 365 & 366 & 367 & 501 & 560 & 561 & 702 & 760 \\
\hline \multicolumn{2}{|c|}{ RELAP5 Table } & 705 & 725 & 708 & 760 & 600 & 700 & 720 & 735 & 730 & 710 & 755 & 750 \\
\hline \multicolumn{2}{|c|}{ Steady-State Power (W) } & 4264.5 & 18078.8 & 1866105.6 & 11879.6 & 14343.3 & 17610.6 & 516.5 & 31752.6 & 189586.2 & 21045440.0 & 391409.7 & 409011.8 \\
\hline \multirow{20}{*}{$\begin{array}{l}\text { Normalized } \\
\text { power } \\
\text { distribution as a } \\
\text { function of axial } \\
\text { segment (left } \\
\text { column is the } \\
\text { structures } \\
\text { segment } \\
\text { number, } 1 \text { is } \\
\text { the top, } 20 \text { is } \\
\text { the bottom) }\end{array}$} & 1 & 0.0068063 & 0.0062588 & 0.0054521 & 0.0044702 & 0.0042589 & 0.0050231 & 0.0062588 & 0.0070036 & 0.0067830 & 0.0060070 & 0.0142095 & 0.0156923 \\
\hline & 2 & 0.0093297 & 0.0089889 & 0.0072555 & 0.0070645 & 0.0064468 & 0.0064546 & 0.0089889 & 0.0098625 & 0.0096655 & 0.0080931 & 0.0142095 & 0.0156923 \\
\hline & 3 & 0.0126375 & 0.0120626 & 0.0098383 & 0.0092783 & 0.0088697 & 0.0088093 & 0.0120626 & 0.0131660 & 0.0129006 & 0.0109221 & 0.0142095 & 0.0156923 \\
\hline & 4 & 0.0164858 & 0.0157260 & 0.0131472 & 0.0125177 & 0.0118903 & 0.0117059 & 0.0157260 & 0.0171255 & 0.0167742 & 0.0143990 & 0.0142095 & 0.0156923 \\
\hline & 5 & 0.0212244 & 0.0205104 & 0.0173040 & 0.0164349 & 0.0157413 & 0.0152868 & 0.0205104 & 0.0218653 & 0.0215198 & 0.0186400 & 0.0301483 & 0.0363310 \\
\hline & 6 & 0.0270225 & 0.0262310 & 0.0224764 & 0.0219305 & 0.0208287 & 0.0202402 & 0.0262310 & 0.0277344 & 0.0272405 & 0.0239416 & 0.0301483 & 0.0363310 \\
\hline & 7 & 0.0343312 & 0.0334502 & 0.0293879 & 0.0282447 & 0.0274374 & 0.0265461 & 0.0334502 & 0.0349419 & 0.0343896 & 0.0307050 & 0.0301483 & 0.0363310 \\
\hline & 8 & 0.0436892 & 0.0427672 & 0.0393217 & 0.0385477 & 0.0375703 & 0.0374804 & 0.0427672 & 0.0437916 & 0.0433314 & 0.0400827 & 0.0301483 & 0.0363310 \\
\hline & 9 & 0.0543809 & 0.0541796 & 0.0527719 & 0.0525824 & 0.0526340 & 0.0532843 & 0.0541796 & 0.0539505 & 0.0538418 & 0.0524261 & 0.0675274 & 0.0654989 \\
\hline & 10 & 0.0648465 & 0.0651306 & 0.0655819 & 0.0653532 & 0.0657180 & 0.0660386 & 0.0651306 & 0.0638753 & 0.0640340 & 0.0643153 & 0.0675274 & 0.0654989 \\
\hline & 11 & 0.0733110 & 0.0740272 & 0.0758496 & 0.0751013 & 0.0751960 & 0.0758123 & 0.0740272 & 0.0721678 & 0.0725113 & 0.0737340 & 0.0675274 & 0.0654989 \\
\hline & 12 & 0.0799013 & 0.0805722 & 0.0830793 & 0.0820725 & 0.0826105 & 0.0829150 & 0.0805722 & 0.0784066 & 0.0788071 & 0.0806118 & 0.0675274 & 0.0654989 \\
\hline & 13 & 0.0836446 & 0.0840831 & 0.0869877 & 0.0870095 & 0.0873110 & 0.0866790 & 0.0840831 & 0.0822398 & 0.0826460 & 0.0847285 & 0.0791970 & 0.0765165 \\
\hline & 14 & 0.0841845 & 0.0851842 & 0.0877217 & 0.0885166 & 0.0889850 & 0.0886134 & 0.0851842 & 0.0835365 & 0.0838960 & 0.0860695 & 0.0791970 & 0.0765165 \\
\hline & 15 & 0.0824701 & 0.0835962 & 0.0861794 & 0.0866065 & 0.0872055 & 0.0871266 & 0.0835962 & 0.0821696 & 0.0825961 & 0.0847197 & 0.0791970 & 0.0765165 \\
\hline & 16 & 0.0781576 & 0.0792715 & 0.0813740 & 0.0817242 & 0.0827736 & 0.0824379 & 0.0792715 & 0.0782750 & 0.0786516 & 0.0806819 & 0.0791970 & 0.0765165 \\
\hline & 17 & 0.0717434 & 0.0722417 & 0.0740556 & 0.0742499 & 0.0754432 & 0.0754539 & 0.0722417 & 0.0719648 & 0.0723676 & 0.0741531 & 0.0589178 & 9613 \\
\hline & 18 & 0.0627850 & 0.0632294 & 0.0646432 & 0.0651055 & 0.0657679 & 0.0656812 & 0.0632294 & 0.0635645 & 0.0638696 & 0.0652627 & 0.0589178 & 0.0559613 \\
\hline & 19 & 0.0525594 & 0.0526552 & 0.0541532 & 0.0548820 & 0.0551890 & 0.0556804 & 0.0526552 & 0.0534160 & 0.0534914 & 0.0549959 & 0.0589178 & 0.0559613 \\
\hline & 20 & 0.0404892 & 0.0398342 & 0.0434194 & 0.0483078 & 0.0481228 & 0.0487309 & 0.0398342 & 0.0409428 & 0.0406828 & 0.0455107 & 0.0589178 & 0.0559613 \\
\hline \multirow{15}{*}{$\begin{array}{l}\text { Relative Power } \\
\text { as a Function of } \\
\text { Time (left } \\
\text { column is time } \\
\text { in seconds } \\
\text { following an } \\
\text { accident } \\
\text { initiated at } 0 \text { s) }\end{array}$} & 0 & 1 & 1 & 1 & 1 & 1 & 1 & 1 & 1 & 1 & 1 & 1 & 1 \\
\hline & 7.5 & 1 & 1 & 1 & 1 & 1 & 1 & 1 & 1 & 1 & 1 & 1 & 1 \\
\hline & 7.51 & 0.3988 & 0.2524 & 0.0461 & 0.0466 & 0.0465 & 0.0465 & 0.2524 & 0.3342 & 0.2574 & 0.0478 & 0.241 & 0.2628 \\
\hline & 8.5 & 0.3938 & 0.2492 & 0.0412 & 0.0417 & 0.0416 & 0.0416 & 0.2492 & 0.33 & 0.2542 & 0.0429 & 0.238 & 0.2595 \\
\hline & 12.5 & 0.3794 & 0.2401 & 0.0342 & 0.0347 & 0.0346 & 0.0346 & 0.2401 & 0.318 & 0.2449 & 0.0358 & 0.2296 & 0.2503 \\
\hline & 17.5 & 0.3684 & 0.2331 & 0.0303 & 0.0307 & 0.0306 & 0.0307 & 0.2331 & 0.3087 & 0.2378 & 0.0318 & 0.2229 & 0.2431 \\
\hline & 22.5 & 0.3605 & 0.2282 & 0.0278 & 0.0282 & 0.0281 & 0.0282 & 0.2282 & 0.3021 & 0.2327 & 0.0293 & 0.2184 & 0.2381 \\
\hline & 27.5 & 0.3545 & 0.2243 & 0.026 & 0.0264 & 0.0263 & 0.0263 & 0.2243 & 0.2971 & 0.2288 & 0.0274 & 0.2147 & 0.2341 \\
\hline & 32.5 & 0.3495 & 0.2212 & 0.0245 & 0.025 & 0.0249 & 0.0249 & 0.2212 & 0.2929 & 0.2256 & 0.026 & 0.2117 & 0.2308 \\
\hline & 37.5 & 0.345 & 0.2183 & 0.0234 & 0.0238 & 0.0237 & 0.0238 & 0.2183 & 0.2891 & 0.2227 & 0.0248 & 0.209 & 0.2279 \\
\hline & 42.5 & 0.341 & 0.2158 & 0.0224 & 0.0228 & 0.0228 & 0.0228 & 0.2158 & 0.2858 & 0.2201 & 0.0238 & 0.2067 & 0.2253 \\
\hline & 47.5 & 0.3373 & 0.2135 & 0.0216 & 0.022 & 0.0219 & 0.0219 & 0.2135 & 0.2827 & 0.2177 & 0.023 & 0.2045 & 0.2229 \\
\hline & 52.5 & 0.334 & 0.2113 & 0.0209 & 0.0213 & 0.0212 & 0.0212 & 0.2113 & 0.2799 & 0.2156 & 0.0222 & 0.2025 & 0.2208 \\
\hline & 57.5 & 0.3309 & 0.2094 & 0.0202 & 0.0206 & 0.0205 & 0.0205 & 0.2094 & 0.2774 & 0.2136 & 0.0216 & 0.2007 & 0.2188 \\
\hline & 60.5 & 0.3309 & 0.2094 & 0.0202 & 0.0206 & 0.0205 & 0.0205 & 0.2094 & 0.2774 & 0.2136 & 0.0216 & 0.2007 & 0.2188 \\
\hline
\end{tabular}


Table C-2 Power specifications for TEST C/600/3 [12]

\begin{tabular}{|c|c|c|c|c|c|c|c|c|c|c|c|c|c|}
\hline \multirow{2}{*}{\multicolumn{2}{|c|}{$\begin{array}{r}\text { Test } \mathrm{C} / 600 / 3 \\
\text { Component }\end{array}$}} & \multicolumn{3}{|c|}{ Remainder of High Heat Flux } & \multicolumn{4}{|c|}{ High heat flux } & \multicolumn{3}{|c|}{ Average Fuel } & \multicolumn{2}{|c|}{ Plugged Channel } \\
\hline & & Structure & Beryllium & Fuel & Plate 4 & Plate 5 & Plate 6 & Beryllium & Structure & Beryllium & Fuel & Structure & Beryllium \\
\hline \multicolumn{2}{|c|}{$\begin{array}{r}\text { RELAP5 Volume } \\
\text { Connections (left/Right) }\end{array}$} & Sym-360 & $360-16$ & $360-360$ & $360-365$ & $365-366$ & 366-367 & $367-16$ & Sym-56 & $56-16$ & Sym-56 & Sym-76 & $76-16$ \\
\hline \multicolumn{2}{|c|}{ Heat Structure } & 301 & 368 & 360 & 364 & 365 & 366 & 367 & 501 & 560 & 561 & 702 & 760 \\
\hline \multicolumn{2}{|c|}{ RELAP5 Table } & 705 & 725 & 708 & 760 & 600 & 700 & 720 & 735 & 730 & 710 & 755 & 750 \\
\hline \multicolumn{2}{|c|}{ Steady-State Power (W) } & 9747.6 & 36236.6 & 2726679.9 & 16628.8 & 20930.9 & 25694.4 & 1035.3 & 95110.5 & 382121.4 & 30800245.0 & 968769.2 & 515957.1 \\
\hline \multirow{20}{*}{$\begin{array}{c}\text { Normalized } \\
\text { power } \\
\text { distribution as a } \\
\text { function of axial } \\
\text { segment (left } \\
\text { column is the } \\
\text { structures } \\
\text { segment } \\
\text { number, } 1 \text { is } \\
\text { the top, } 20 \text { is } \\
\text { the bottom) }\end{array}$} & 1 & 0.0189323 & 0.0178070 & 0.0059885 & 0.0050738 & 0.0047870 & 0.0055380 & 0.0178070 & 0.0186202 & 0.0182402 & 0.0065392 & 0.0248469 & 0.0217014 \\
\hline & 2 & 0.0115826 & 0.0112167 & 0.0080003 & 0.0077075 & 0.0073537 & 0.0071234 & 0.0112167 & 0.0115862 & 0.0114728 & 0.0087843 & 0.0248469 & 0.0217014 \\
\hline & 3 & 0.0154127 & 0.0149883 & 0.0108108 & 0.0104423 & 0.0098233 & 0.0096375 & 0.0149883 & 0.0154002 & 0.0151735 & 0.0117839 & 0.0248469 & 0.0217014 \\
\hline & 4 & 0.0203392 & 0.0193738 & 0.0144172 & 0.0138624 & 0.0131665 & 0.0130144 & 0.0193738 & 0.0199671 & 0.0195084 & 0.0155746 & 0.0248469 & 0.0217014 \\
\hline & 5 & 0.0258837 & 0.0245787 & 0.0188910 & 0.0182646 & 0.0176145 & 0.0169550 & 0.0245787 & 0.0253662 & 0.0246964 & 0.0201378 & 0.0301089 & 0.0383387 \\
\hline & 6 & 0.0323575 & 0.0307089 & 0.0247286 & 0.0238697 & 0.0228256 & 0.0218867 & 0.0307089 & 0.0315481 & 0.0307139 & 0.0258402 & 0.0301089 & 0.0383387 \\
\hline & 7 & 0.0393535 & 0.0387414 & 0.0325537 & 0.0321555 & 0.0309250 & 0.0303245 & 0.0387414 & 0.0385575 & 0.0384629 & 0.0333935 & 0.0301089 & 0.0383387 \\
\hline & 8 & 0.0471128 & 0.0467426 & 0.0438924 & 0.0435870 & 0.0426535 & 0.0435825 & 0.0467426 & 0.0462320 & 0.0462141 & 0.0440885 & 0.0301089 & 0.0383387 \\
\hline & 9 & 0.0542983 & 0.0548483 & 0.0568524 & 0.0562289 & 0.0563302 & 0.0571806 & 0.0548483 & 0.0537440 & 0.0539838 & 0.0560514 & 0.0587785 & 0.0607254 \\
\hline & 10 & 0.0612365 & 0.0626750 & 0.0682092 & 0.0671047 & 0.0674075 & 0.0678137 & 0.0626750 & 0.0604644 & 0.0616206 & 0.0661529 & 0.0587785 & 0.0607254 \\
\hline & 11 & 0.0669662 & 0.0690334 & 0.0760861 & 0.0757645 & 0.0760636 & 0.0762745 & 0.0690334 & 0.0664778 & 0.0678068 & 0.0741367 & 0.0587785 & 0.0607254 \\
\hline & 12 & 0.0721942 & 0.0741261 & 0.0815056 & 0.0812460 & 0.0810957 & 0.0812536 & 0.0741261 & 0.0716025 & 0.0729490 & 0.0796356 & 0.0587785 & 0.0607254 \\
\hline & 13 & 0.0755760 & 0.0771691 & 0.0843979 & 0.0838946 & 0.0845738 & 0.0842291 & 0.0771691 & 0.0751540 & 0.0762864 & 0.0828052 & 0.0665939 & 0.0678613 \\
\hline & 14 & 0.0772335 & 0.0776212 & 0.0852490 & 0.0851730 & 0.0850609 & 0.0854833 & 0.0776212 & 0.0766175 & 0.0771078 & 0.0836615 & 0.0665939 & 0.0678613 \\
\hline & 15 & 0.0759241 & 0.0737225 & 0.0832077 & 0.0834513 & 0.0843266 & 0.0841518 & 0.0737225 & 0.0754482 & 0.0736985 & 0.0820805 & 0.0665939 & 0.0678613 \\
\hline & 16 & 0.0716937 & 0.0696920 & 0.0783315 & 0.0787792 & 0.0793790 & 0.0796611 & 0.0696920 & 0.0713783 & 0.0699187 & 0.0780094 & 0.0665939 & 0.0678613 \\
\hline & 17 & 0.0642647 & 0.0633289 & 0.0712187 & 0.0713830 & 0.0724150 & 0.0725645 & 0.0633289 & 0.0648096 & 0.0639372 & 0.0715028 & 0.0696719 & 0.0613733 \\
\hline & 18 & 0.0545281 & 0.0551637 & 0.0619329 & 0.0625594 & 0.0635487 & 0.0632394 & 0.0551637 & 0.0560923 & 0.0560810 & 0.0627349 & 0.0696719 & 0.0613733 \\
\hline & 19 & 0.0438435 & 0.0456407 & 0.0519634 & 0.0529373 & 0.0532057 & 0.0527147 & 0.0456407 & 0.0463115 & 0.0467802 & 0.0529406 & 0.0696719 & 0.0613733 \\
\hline & 20 & 0.0712671 & 0.0728215 & 0.0417633 & 0.0465153 & 0.0474444 & 0.0473715 & 0.0728215 & 0.0746223 & 0.0753477 & 0.0441467 & 0.0696719 & 0.0613733 \\
\hline \multirow{15}{*}{$\begin{array}{l}\text { Relative power } \\
\text { as a function of } \\
\text { time (left } \\
\text { column is time } \\
\text { in seconds } \\
\text { following an } \\
\text { accident } \\
\text { initiated at } 0 \mathrm{~s} \text { ) }\end{array}$} & 0 & 1 & 1 & 1 & 1 & 1 & 1 & 1 & 1 & 1 & 1 & 1 & 1 \\
\hline & 6.55 & 1 & 1 & 1 & 1 & 1 & 1 & 1 & 1 & 1 & 1 & 1 & 1 \\
\hline & 6.56 & 0.3489 & 0.2529 & 0.0489 & 0.0493 & 0.0491 & 0.0491 & 0.2529 & 0.3257 & 0.2564 & 0.0488 & 0.241 & 0.2628 \\
\hline & 7.55 & 0.3446 & 0.2498 & 0.0438 & 0.0443 & 0.044 & 0.0441 & 0.2498 & 0.3217 & 0.2533 & 0.0438 & 0.238 & 0.2595 \\
\hline & 11.55 & 0.3324 & 0.2409 & 0.0366 & 0.0371 & 0.0368 & 0.0368 & 0.2409 & 0.3103 & 0.2443 & 0.0365 & 0.2296 & 0.2503 \\
\hline & 16.55 & 0.3228 & 0.234 & 0.0325 & 0.0329 & 0.0327 & 0.0327 & 0.234 & 0.3014 & 0.2373 & 0.0324 & 0.2229 & 0.2431 \\
\hline & 21.55 & 0.3162 & 0.2292 & 0.0299 & 0.0303 & 0.0301 & 0.0301 & 0.2292 & 0.2952 & 0.2324 & 0.0299 & 0.2184 & 0.2381 \\
\hline & 26.55 & 0.311 & 0.2254 & 0.028 & 0.0284 & 0.0282 & 0.0282 & 0.2254 & 0.2903 & 0.2285 & 0.028 & 0.2147 & 0.2341 \\
\hline & 31.55 & 0.3067 & 0.2223 & 0.0266 & 0.027 & 0.0267 & 0.0267 & 0.2223 & 0.2863 & 0.2254 & 0.0265 & 0.2117 & 0.2308 \\
\hline & 36.55 & 0.3029 & 0.2195 & 0.0254 & 0.0258 & 0.0255 & 0.0255 & 0.2195 & 0.2827 & 0.2226 & 0.0253 & 0.209 & 0.2279 \\
\hline & 41.55 & 0.2994 & 0.217 & 0.0243 & 0.0248 & 0.0245 & 0.0245 & 0.217 & 0.2795 & 0.22 & 0.0243 & 0.2067 & 0.2253 \\
\hline & 46.55 & 0.2963 & 0.2148 & 0.0235 & 0.0239 & 0.0236 & 0.0237 & 0.2148 & 0.2766 & 0.2177 & 0.0234 & 0.2045 & 0.2229 \\
\hline & 56.55 & 0.2908 & 0.2108 & 0.022 & 0.0224 & 0.0222 & 0.0222 & 0.2108 & 0.2715 & 0.2137 & 0.022 & 0.2025 & 0.2208 \\
\hline & 66.55 & 0.2859 & 0.2073 & 0.0209 & 0.0213 & 0.021 & 0.021 & 0.2073 & 0.2669 & 0.2101 & 0.0208 & 0.2007 & 0.2188 \\
\hline & 70 & 0.2859 & 0.2073 & 0.0209 & 0.0213 & 0.021 & 0.021 & 0.2073 & 0.2669 & 0.2101 & 0.0208 & 0.2007 & 0.2188 \\
\hline
\end{tabular}


Table C-3 Power specifications for Test F/400/1 [12]

\begin{tabular}{|c|c|c|c|c|c|c|c|c|c|c|c|c|c|}
\hline \multirow{2}{*}{\multicolumn{2}{|c|}{$\begin{array}{r}\text { Test } \mathrm{F} / 400 / 1 \\
\text { Component }\end{array}$}} & \multicolumn{3}{|c|}{ Remainder of High Heat Flux } & \multicolumn{4}{|c|}{ High heat flux } & \multicolumn{3}{|c|}{ Average Fuel } & \multicolumn{2}{|c|}{ Plugged Channel } \\
\hline & & Structure & Beryllium & Fuel & Plate 4 & Plate 5 & Plate 6 & Beryllium & Structure & Beryllium & Fuel & Structure & Beryllium \\
\hline \multicolumn{2}{|c|}{$\begin{array}{r}\text { RELAP5 Volume } \\
\text { Connections (left/Right) }\end{array}$} & Sym-360 & $360-16$ & $360-360$ & $360-365$ & $365-366$ & $366-367$ & $367-16$ & Sym-56 & $56-16$ & Sym-56 & Sym-76 & $76-16$ \\
\hline \multicolumn{2}{|c|}{ Heat Structure } & 301 & 368 & 360 & 364 & 365 & 366 & 367 & 501 & 560 & 561 & 702 & 760 \\
\hline \multicolumn{2}{|c|}{ RELAP5 Table } & 705 & 725 & 708 & 760 & 600 & 700 & 720 & 735 & 730 & 710 & 755 & 750 \\
\hline \multicolumn{2}{|c|}{ Steady-State Power (W) } & 6645.2 & 24478.4 & 1826112.2 & 11077.4 & 14068.3 & 17272.5 & 699.4 & 64481.6 & 257558.0 & 20519105.9 & 646649.6 & 345975.1 \\
\hline \multirow{20}{*}{$\begin{array}{l}\text { Normalized } \\
\text { power } \\
\text { distribution as a } \\
\text { function of axial } \\
\text { segment (left } \\
\text { column is the } \\
\text { structures } \\
\text { segment } \\
\text { number, } 1 \text { is } \\
\text { the top, } 20 \text { is } \\
\text { the bottom) }\end{array}$} & 1 & 0.0227713 & 0.0217634 & 0.0074054 & 0.0063252 & 0.0060112 & 0.0069250 & 0.0217634 & 0.0224570 & 0.0221097 & 0.0080367 & 0.0274840 & 0.0256834 \\
\hline & 2 & 0.0141212 & 0.0138565 & 0.0099613 & 0.0095699 & 0.0090445 & 0.0089620 & 0.0138565 & 0.0140673 & 0.0140497 & 0.0108481 & 0.0274840 & 0.0256834 \\
\hline & 3 & 0.0191102 & 0.0185118 & 0.0137150 & 0.0131561 & 0.0125345 & 0.0123584 & 0.0185118 & 0.0187513 & 0.0185961 & 0.0146982 & 0.0274840 & 0.0256834 \\
\hline & 4 & 0.0249594 & 0.0240173 & 0.0185670 & 0.0179606 & 0.0170219 & 0.0168752 & 0.0240173 & 0.0244073 & 0.0239746 & 0.0195943 & 0.0274840 & 0.0256834 \\
\hline & 5 & 0.0318244 & 0.0304817 & 0.0249283 & 0.0243206 & 0.0234537 & 0.0232084 & 0.0304817 & 0.0310257 & 0.0303194 & 0.0259643 & 0.0376305 & 0.0429637 \\
\hline & 6 & 0.0394429 & 0.0376740 & 0.0341651 & 0.0333329 & 0.0325347 & 0.0335068 & 0.0376740 & 0.0385304 & 0.0372967 & 0.0348378 & 0.0376305 & 0.0429637 \\
\hline & 7 & 0.0470255 & 0.0462066 & 0.0459694 & 0.0455012 & 0.0449250 & 0.0457402 & 0.0462066 & 0.0461535 & 0.0455736 & 0.0455584 & 0.0376305 & 0.0429637 \\
\hline & 8 & 0.0538046 & 0.0536570 & 0.0568598 & 0.0562064 & 0.0555945 & 0.0565107 & 0.0536570 & 0.0530202 & 0.0527376 & 0.0554001 & 0.0376305 & 0.0429637 \\
\hline & 9 & 0.0595519 & 0.0601034 & 0.0652459 & 0.0643746 & 0.0645551 & 0.0646757 & 0.0601034 & 0.0587991 & 0.0590667 & 0.0635454 & 0.0600328 & 0.0620618 \\
\hline & 10 & 0.0635332 & 0.0656889 & 0.0715774 & 0.0701494 & 0.0713147 & 0.0714301 & 0.0656889 & 0.0631985 & 0.0646154 & 0.0698264 & 0.0600328 & 0.0620618 \\
\hline & 11 & 0.0675283 & 0.0696136 & 0.0761948 & 0.0755954 & 0.0755742 & 0.0758121 & 0.0696136 & 0.0670953 & 0.0684907 & 0.0744329 & 0.0600328 & 0.0620618 \\
\hline & 12 & 0.0703255 & 0.0723853 & 0.0785740 & 0.0786325 & 0.0788008 & 0.0792213 & 0.0723853 & 0.0701673 & 0.0715473 & 0.0771923 & 0.0600328 & 0.0620618 \\
\hline & 13 & 0.0717772 & 0.0734620 & 0.0790516 & 0.0790722 & 0.0798284 & 0.0792828 & 0.0734620 & 0.0718298 & 0.0729415 & 0.0778967 & 0.0621522 & 0.0639117 \\
\hline & 14 & 0.0720196 & 0.0722189 & 0.0774972 & 0.0777812 & 0.0782946 & 0.0777147 & 0.0722189 & 0.0716975 & 0.0721693 & 0.0769111 & 0.0621522 & 0.0639117 \\
\hline & 15 & 0.0697374 & 0.0675866 & 0.0747046 & 0.0748628 & 0.0757705 & 0.0749252 & 0.0675866 & 0.0694316 & 0.0678969 & 0.0742110 & 0.0621522 & 0.0639117 \\
\hline & 16 & 0.0648681 & 0.0630727 & 0.0694927 & 0.0702495 & 0.0701415 & 0.0700195 & 0.0630727 & 0.0648342 & 0.0635018 & 0.0694553 & 0.0621522 & 0.0639117 \\
\hline & 17 & 0.0577265 & 0.0567056 & 0.0622947 & 0.0628410 & 0.0636188 & 0.0627855 & 0.0567056 & 0.0581730 & 0.0574478 & 0.0629537 & 0.0627007 & 0.0553794 \\
\hline & 18 & 0.0485490 & 0.0489591 & 0.0536011 & 0.0545041 & 0.0547322 & 0.0545997 & 0.0489591 & 0.0499682 & 0.0500016 & 0.0547691 & 0.0627007 & 0.0553794 \\
\hline & 19 & 0.0388168 & 0.0401643 & 0.0445173 & 0.0450462 & 0.0457487 & 0.0455388 & 0.0401643 & 0.0408901 & 0.0413448 & 0.0458207 & 0.0627007 & 0.0553794 \\
\hline & 20 & 0.0625069 & 0.0638712 & 0.0356773 & 0.0405181 & 0.0405005 & 0.0399080 & 0.0638712 & 0.0655027 & 0.0663187 & 0.0380475 & 0.0627007 & 0.0553794 \\
\hline \multirow{15}{*}{$\begin{array}{l}\text { Relative power } \\
\text { as a function of } \\
\text { time (left } \\
\text { column is time } \\
\text { in seconds } \\
\text { following an } \\
\text { accident } \\
\text { initiated at } 0 \mathrm{~s} \text { ) }\end{array}$} & 0 & 1 & 1 & 1 & 1 & 1 & 1 & 1 & 1 & 1 & 1 & 1 & 1 \\
\hline & 11.1 & 1 & 1 & 1 & 1 & 1 & 1 & 1 & 1 & 1 & 1 & 1 & 1 \\
\hline & 11.11 & 0.3737 & 0.2731 & 0.0504 & 0.0509 & 0.0505 & 0.0505 & 0.2731 & 0.3486 & 0.2759 & 0.0503 & 0.241 & 0.2628 \\
\hline & 12.1 & 0.3695 & 0.27 & 0.0454 & 0.0458 & 0.0455 & 0.0455 & 0.27 & 0.3447 & 0.2728 & 0.0453 & 0.238 & 2595 \\
\hline & 16.1 & 0.3575 & 0.2612 & 0.0381 & 0.0386 & 0.0382 & 0.0382 & 0.2612 & 0.3335 & 0.2639 & 0.038 & 0.2296 & 0.2503 \\
\hline & 21.1 & 0.3481 & 0.2543 & 0.034 & 0.0344 & 0.0341 & 0.0341 & 0.2543 & 0.3247 & 0.257 & 0.0339 & 0.2229 & 0.2431 \\
\hline & 26.1 & 0.3414 & 0.2495 & 0.0314 & 0.0318 & 0.0315 & 0.0315 & 0.2495 & 0.3185 & 0.2521 & 0.0313 & 0.2184 & 0.2381 \\
\hline & 31.1 & 0.3364 & 0.2458 & 0.0295 & 0.03 & 0.0296 & 0.0297 & 0.2458 & 0.3138 & 0.2483 & 0.0295 & 0.2147 & 0.2341 \\
\hline & 36.1 & 0.332 & 0.2426 & 0.0281 & 0.0285 & 0.0282 & 0.0282 & 0.2426 & 0.3097 & 0.2451 & 0.028 & 0.2117 & 0.2308 \\
\hline & 41.1 & 0.3283 & 0.2399 & 0.0269 & 0.0273 & 0.027 & 0.027 & 0.2399 & 0.3063 & 0.2424 & 0.0268 & 0.209 & 0.2279 \\
\hline & 46.1 & 0.325 & 0.2375 & 0.0259 & 0.0263 & 0.026 & 0.026 & 0.2375 & 0.3031 & 0.2399 & 0.0258 & 0.2067 & 0.2253 \\
\hline & 51.1 & 0.3219 & 0.2352 & 0.025 & 0.0254 & 0.0251 & 0.0251 & 0.2352 & 0.3002 & 0.2376 & 0.0249 & 0.2045 & 0.2229 \\
\hline & 61.1 & 0.3164 & 0.2312 & 0.0236 & 0.0239 & 0.0236 & 0.0237 & 0.2312 & 0.2951 & 0.2336 & 0.0235 & 0.2025 & 0.2208 \\
\hline & 71.1 & 0.3117 & 0.2278 & 0.0224 & 0.0228 & 0.0225 & 0.0225 & 0.2278 & 0.2908 & 0.2301 & 0.0223 & 0.2007 & 0.2188 \\
\hline & 74.55 & 0.3117 & 0.2278 & 0.0224 & 0.0228 & 0.0225 & 0.0225 & 0.2278 & 0.2908 & 0.2301 & 0.0223 & 0.2007 & 0.2188 \\
\hline
\end{tabular}




\section{Estimation of Peak Cladding Temperature Due to Flow Reversal}

The peak cladding temperature due to flow reversal can be calculated using Newton's law of cooling:

$$
Q=h A\left(T_{w}-T_{b}\right)
$$

In this equation, the local decay power $(Q)$ is a variable evaluated parametrically as function of the assumed time that flow reversal occurs. Under natural convection conditions, the heat transfer coefficient was evaluated with the Churchill correlation evaluated at the bulk coolant conditions:

$$
N u=\frac{h L}{k_{b}}=\left[0.825+\frac{0.387 R a_{b}{ }^{1 / 6}}{\left(1+\left[\frac{0.492}{P r_{b}}\right]^{9 / 16}\right)^{8 / 27}}\right]^{2}
$$

where the Rayleigh number was determined from:

$$
R a_{b}=\frac{g \beta_{b}\left(T_{w}-T_{b}\right) L^{3} \rho_{b}^{2}}{\mu_{b}^{2}} P r_{b}
$$

In determining a lower bound for the peak cladding temperature the bulk coolant temperature can be evaluated at cold conditions (i.e. $\mathrm{T}_{\mathrm{b}}=35 \mathrm{C}$ ).

Determining an upper bound on the peak cladding temperature requires conservatively estimating how high the bulk coolant temperature will peak within the channel. Simulations show that peak coolant temperature occurs approximately at the time when the channel flow has just established itself. In other words, at a time when the balance between the flow resistance and buoyancy has been reached:

$$
d P=f \frac{L}{D_{h}} \rho_{r e f} V^{2}=\left(\rho_{\text {ref }}-\rho_{b}\right) g L
$$

A characteristic residence time for a slug of coolant in the channel was approximated by the time it takes the coolant to travel the length of the channel at the established velocity $\left(t \approx \frac{L}{V}\right)$. This estimate can be justified by the RELAP5 simulation results where it shows the coolant temperature rate of change prior to and following establishment of the flow are relatively similar (in the channel containing the peak clad temperature). In other words, the time it takes the coolant to go from cold conditions to the peak temperature following flow stagnation is similar to the time in going from the peak coolant temperature back to cold conditions after the natural circulation flow has been established. Conservatively assuming the slug of coolant remains in the high heat flux region for this duration, the temperature (enthalpy) rise of the bulk coolant can be evaluated $\left(i_{b}=i_{\text {ref }}+\frac{E}{m} ; m=\rho_{b} \cdot\right.$ Volume; $\left.E=Q \cdot t\right)$. Implicitly solving the set of equations, while parametrically evaluating the decay heat value, provides an estimate to the upper bound of the peak cladding temperature as function of time at which flow reversal might occur. 
(This page intentionally left blank) 


\section{Argonne}

\section{Nuclear Engineering Division}

Argonne National Laboratory

9700 South Cass Avenue, Bldg. 208

Argonne, IL 60439-4842 